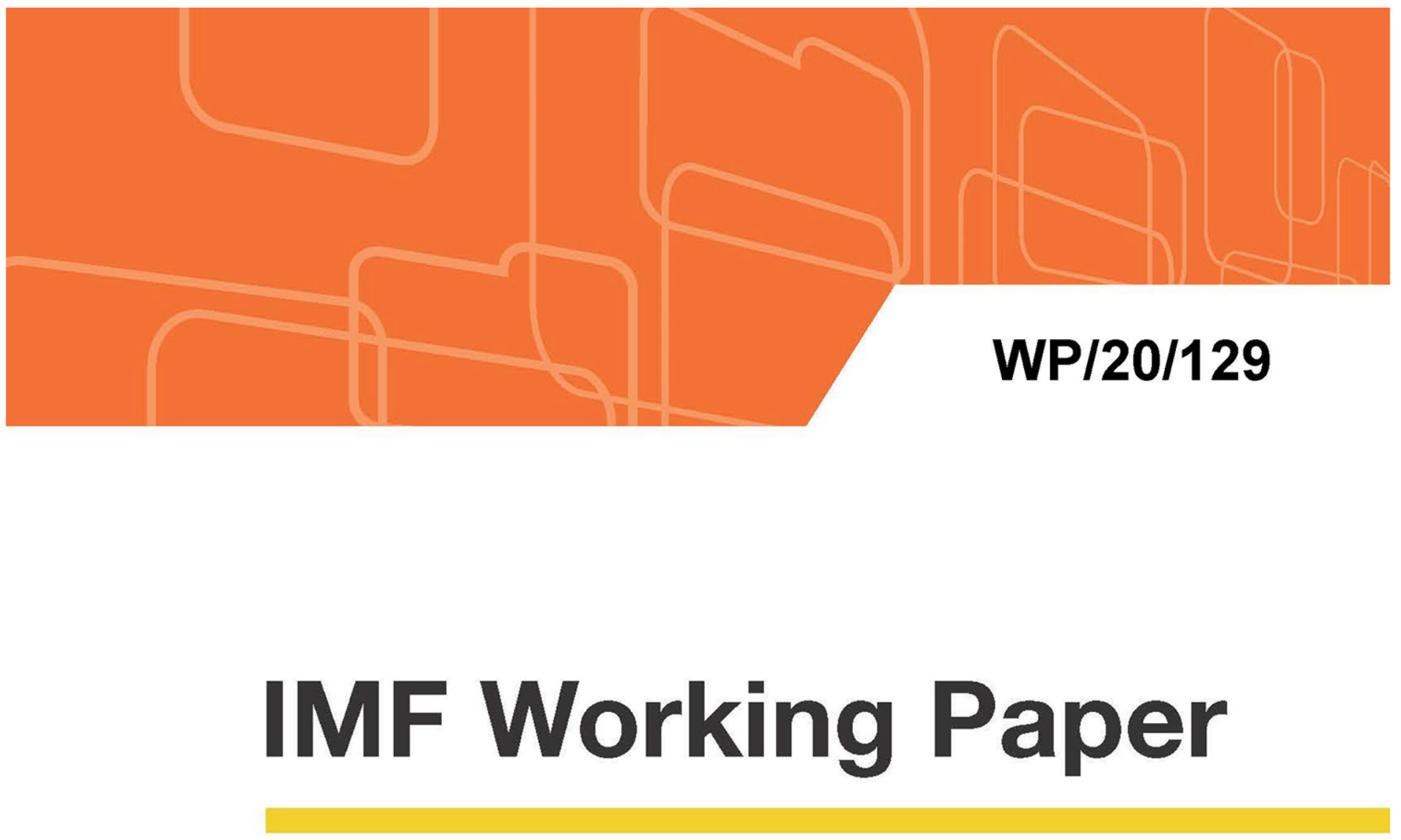

\title{
Measuring Social Unrest Using Media Reports
}

by Philip Barrett, Maximiliano Appendino, Kate Nguyen, and Jorge de Leon Miranda

IMF Working Papers describe research in progress by the author(s) and are published to elicit comments and to encourage debate. The views expressed in IMF Working Papers are those of the author(s) and do not necessarily represent the views of the IMF, its Executive Board, or IMF management. 


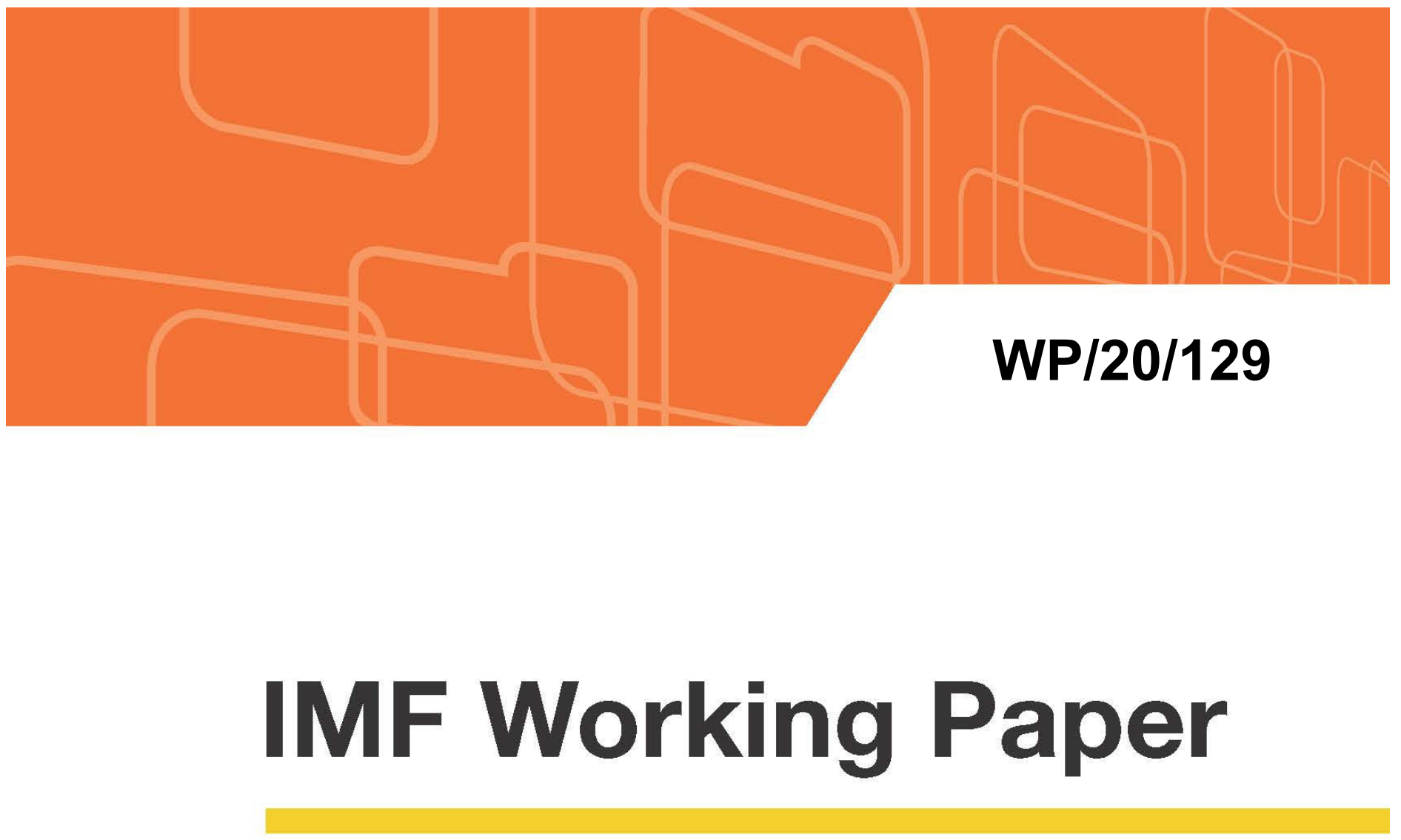

\section{Measuring Social Unrest Using Media Reports}

by Philip Barrett, Maximiliano Appendino, Kate Nguyen, and Jorge de Leon Miranda

IMF Working Papers describe research in progress by the author(s) and are published to elicit comments and to encourage debate. The views expressed in IMF Working Papers are those of the author(s) and do not necessarily represent the views of the IMF, its Executive Board, or IMF management. 


\title{
IMF Working Paper
}

Research and Middle East and Central Asia Departments

Measuring Social Unrest Using Media Reports

\section{Prepared by Philip Barrett, Maximiliano Appendino, Kate Nguyen, and Jorge de Leon Miranda}

Authorized for distribution by Bikas Joshi and Malhar Nabar

July 2020

IMF Working Papers describe research in progress by the author(s) and are published to elicit comments and to encourage debate. The views expressed in IMF Working Papers are those of the author(s) and do not necessarily represent the views of the IMF, its Executive Board, or IMF management.

\begin{abstract}
We present a new index of social unrest based on counts of relevant media reports. The index consists of individual monthly time series for 130 countries, available with almost no lag, and can be easily and transparently replicated. Spikes in the index identify major events, which correspond very closely to event timelines from external sources for four major regional waves of social unrest. We show that the cross-sectional distribution of the index can be simply and precisely characterized, and that social unrest is associated with a 3 percentage point increase in the frequency of social unrest domestically and a 1 percent increase in neighbors in the next six months. Despite this, social unrest is not a better predictor of future social unrest than the country average rate.
\end{abstract}

JEL Classification Numbers: F00, F50, H0

Keywords: Social Unrest, Protest, Media

Author's E-Mail Address: pbarrett@,imf.org, mappendino@,imf.org, knguyen3@imf.org 


\title{
Measuring Social Unrest Using Media Reports
}

\author{
Philip Barrett, Maximiliano Appendino, Kate Nguyen, and Jorge de Leon Miranda ${ }^{\dagger}$
}

June 2020

\begin{abstract}
We present a new index of social unrest based on counts of relevant media reports. The index consists of individual monthly time series for 130 countries, available with almost no lag, and can be easily and transparently replicated. Spikes in the index identify major events, which correspond very closely to event timelines from external sources for four major regional waves of social unrest. We show that the cross-sectional distribution of the index can be simply and precisely characterized, and that social unrest is associated with a 3 percentage point increase in the frequency of social unrest domestically and a 1 percent increase in neighbors in the next six months. Despite this, social unrest is not a better predictor of future social unrest than the country average rate.
\end{abstract}

\section{Introduction}

Social unrest is a major social issue in many countries across the world. During just the second half of 2019, major protests or other forms of disorder occurred in locations as diverse as Bolivia, Chile, France, Hong Kong, India, Iraq, and Lebanon. Such unrest has a natural connection to economic questions, as economic factors may contribute to social unrest. For example, increases in taxes and fuel prices were important triggers for recent protests in Lebanon and Iran, respectively. Moreover, disruption stemming from social unrest can have economic consequences, potentially interrupting trade and dissuading investment.

Of course, answering questions about the relationship between social unrest and economic or financial outcomes necessitates data on social unrest. Without knowing, at the very least, where and when major social unrest events have occurred, it is hard to make progress on such issues. Yet data on social unrest are largely unsatisfactory. There is - as far as we know - no transparent, high-frequency, timely indicator of social unrest with broad and consistent coverage across countries and periods. This paper is an attempt to fill that gap.

We introduce a new measure of social unrest, as measured by media reports, which we term the

${ }^{*}$ Corresponding author, email: pbarrett@imf.org

${ }^{\dagger}$ Luisa Calixto, Grey Ramos, and Jordan Miller provided excellent research assistance. 
Reported Social Unrest Index (RSUI). ${ }^{1}$ Coverage is broad: we provide data on 130 countries from January 1985 to May 2020. Measurement criteria are consistent and transparent: we use the same set of sources and search terms throughout, and any country-specific adjustments are reported and justified. The index is high-frequency and timely: data are available for each month with only a few days lag. This makes the index useful not only for research but also for contemporaneous monitoring of cross-country social unrest episodes.

In this paper, we detail how we construct the RSUI and how large movements can be used to identify major events. By comparing our results to several case studies of major, well-known social unrest episodes, we argue that the index and the coded events reflect respected narrative descriptions of real events, and are not simply the product of media fads or biases. We also analyze the statistical properties of the index and present three key findings, all of which are essential context for future work. First, that the units of the RSUI have a natural interpretation, consistent across and within countries: that a one percent increase in the index reduces the fraction of higher observations by approximately two percent. Second, that social unrest events are typically associated with around a three percentage point increase in the probability of social unrest in the same country and a one percentage point increase in neighboring countries during the next six months. Third, that despite this correlation, past social unrest is not a good predictor of future unrest, which we interpret as reflecting the fact that social unrest is a low-probability event driven by disparate factors.

The next section discusses related economic literature. Section 3 outlines the calculation of the RSUI and how we identify major social unrest events from it. Section 4 discusses the internal and external consistency of our measures. And section 5 investigates the properties of the time-series and cross-country variation of this index.

\section{Related Literature}

Our work contributes to the rapidly growing literature on text search methods using newspaper archives. Initially, this literature focused on measuring economic policy uncertainty. The seminal paper is by Baker et al. (2016), who construct an index of economic policy uncertainty (EPU) for 12 major economies using newspaper archives back to 1985. They show that the EPU is associated with lower investment and employment, and higher stock price volatility. Similarly, Ahir et al. (2018) construct a World Uncertainty Index (WUI) for 143 individual countries on a quarterly basis from 1996 onwards. Their index measures the frequency of the word "uncertainty" in the quarterly Economist Intelligence Unit country reports. And in a country-specific setting, Jirasavetakul and Spilimbergo (2018) develop a news-based economic policy uncertainty (EPU) index for Turkey. The index measures the frequency of news articles about economic policy uncertainty and, as we do, uses Factiva as the primary source.

\footnotetext{
${ }^{1}$ Early versions of the RSUI, covering initially only seven countries in the Middle East and North Africa and later the whole of the Middle East and Central Asia, featured in the IMF's Regional Economic Outlook in April and October 2019.
} 
Other authors use text-based indices proxy for sentiment in financial markets, geopolitical tensions, and corruption. Manela and Moreira (2017) calculate a text-based measure of uncertainty starting in 1890 using front-page articles of the Wall Street Journal. They show that periods when their index is high are followed by periods of above average stock returns. To examine the effects that media sentiment has on equity prices, Fraiberger et al. (2018) create a daily news-based sentiment index for 25 advanced and emerging economies between 1991 and 2015. They restrict their sample to articles published by Reuters in English, and develop an algorithm which quantifies tone, counting the number of positive and negative words within financial, political and economic texts. Caldara and Iacoviello (2018) construct a monthly measure of geopolitical risk based on a set of newspaper articles covering geopolitical tensions since 1985. Like us, these authors use an algorithm which counts the frequency of articles that refer to geopolitical risks in leading newspapers published in the US, UK, and Canada, although in their case ProQuest Historical Newspapers and ProQuest News stream are the primary sources. Finally, Hlatshwayo et al. (2018) construct a cross-country news-based flow indexes of corruption and anti-corruption by reviewing 665 million international news articles provided by Factiva. They show that shocks in the corruption index are associated to negative impacts on asset prices and economic activity.

Clearly, our work is closely related to other measures of social unrest. There are three main alternatives to our approach: the Cross-National Time-Series Data (CNTSD) database by Banks and Wilson (2020); the Armed Conflict Location and Event Database (ACLED); and the Mass Mobilization in Autocracies Database (MMAD) by Hellmeier et al. (2019) are alternatives to measure social unrest worldwide. The temporal and spatial coverage of the CNTSD is comprehensive - it provides annual time series data since 1815 covering 200 countries for the number of riots and anti-government demonstrations. Yet despite its wide usage, the CNTSD suffers from three significant drawbacks. First, it is at annual frequency and is typically updated with a lag of at least a year. Second, it identifies only a small number of events per year so the marginal impact of a new event can be substantial. Third, the results can be somewhat hard to interrogate, with the relationship between increases in the CNTSD series and events on the ground not always compelling (see Appendix $\mathrm{C}$ for further illustration of this point).

The ACLED is a high-quality source with monthly observations. Within sub-Saharan Africa, coverage is broad and begins in the late-1990s. Coverage elsewhere, though, is rather limited. Finally, the MMAD has information about individual protest events generated by a combined machine learning and human coding process from three newswire agencies: The Associated Press, the Agence France-Presse and BBC Monitoring. However, the covers only a few countries from 2005 to 2012.

Several articles have used the CNTSD and the MMAD to proxy for social unrest in crosscountry statistical analysis of political and economic phenomena, and a few articles have exploited the ACLED's more granular data in the context of Sub-Saharan Africa. The political science literature used these data extensively to study social unrest and related political issues in a crosscountry setting -see for example, Bodnaruk Jazayeri's (2016) analysis of the impact of identity- 
based political inequality on protest in MENA using CNTSD, or Ciocan and Wüest (2016) for an application of the MMAD to analysis of media censorship in MENA countries during the Arab Uprisings of 2011. The economics literature tended to use CTSD more frequently for cross-country econometric analysis of long-run issues - see for example, Acemoglu et al. (2019), who use this data to explore the relationship between democracy and economic growth, or Barro's (1991) classic paper on economic growth where variables from this dataset are used as controls for political instability. Some more recent studies look at higher frequency economic phenomena, such as empirical analysis on budget cuts, and to social unrest in Europe by Ponticelli and Voth (2020). The political science and economics literature has also worked with ACLED focusing on Sub-Saharan Africa and benefiting from its detailed coverage -see for example, Harari and Ferrara (2018), and Ali et al. (2019).

\section{The Reported Social Unrest Index}

In this section we explain how the RSUI is created and a method for coding peaks into major events. We discuss how concerns for robustness influence the design of the methodology and report basic properties of the index.

\subsection{Data}

The primary source is Dow Jones' Factiva news aggregator. We restrict our sample to printed articles published by major English-language newspapers and networks in the USA, UK, and Canada. Specifically: the ABC Network, the BBC, the CBS Network, the Canadian Broadcasting Corp, the NBC Network, the Los Angeles Times, the Financial Times, the Boston Globe, the Globe and Mail, the New York Times, the Telegraph U.K., the Times U.K., the Chicago Tribune, the Telegraph, the Guardian U.K., the Wall Street Journal, the Washington Post, and the Economist. This is a very similar set of sources to Caldara and Iacoviello (2018).

This choice of sources is motivated by several factors. First, this produces a very large sample over a long period of time, with our headline measure of relevant articles rising from around 7,000 per month in 1985 to over 20,000 between 2000 and the present, totaling over 7 million articles (see Figure 1). Second, by selecting well-known sources, we can be completely transparent about the possible biases in our sources. Of course, no sources are entirely free of bias, but these sources are ones that a large set of users is familiar with, and so can caveat the results as they see fit. This is not true about either less well-known sources or newer media, such as Twitter or Facebook, where one cannot easily understand the likely biases of individual commenters. This latter group of sources suffer from further challenges, as it is difficult to know how to account for changes in penetration and composition or the role of bots, trolls, and other nefarious actors. Similarly, by limiting our sample to only foreign news media, we hope to avoid the most nakedly political sources, as within-country publications might have specific agendas which influence their reporting of civil unrest.

CInternational Monetary Fund. Not for Redistribution 




Figure 1: Number of contemporary articles per month, $z_{t}$

Nevertheless, in Section 4.2 we also provide further robustness checks, examining the possible impact of these arguments for a selection of Middle Eastern countries, including using different English-language sources, alternate search terms, and French and Arabic language media. And when constructing the RSUI from the raw data, we also take account of how possible media bias might be mitigated by the specific details of the design of the index, discussed further below.

Using these sources, we collect three monthly article counts:

$x_{i t}$ : Number of articles about social unrest in country $i$ at period $t$

$y_{i t}$ : Number of contemporary articles in country $i$ at period $t$

$z_{t}$ : Number of contemporary articles in period $t$

Our sample includes the 130 countries countries with at least one million inhabitants and 200 social unrest articles (i.e. $\sum_{t} x_{i t} \geq 200$ ).

The search criteria defining these three series vary principally in the text strings tha must match in order for an article to be counted (see Table 1). This is most involved for $x_{i t}$, which has both inclusive and exclusive requirements. The inclusive requirements aim to pick up specific events related to civil unrest events, including protests, riots, major demonstrations, and other forms of unrest. The exclusive requirements aim to prevent false positives. These are either country-specific (more on this in Section 3.4), or aim to prevent matches from mis-use of search terms, ${ }^{2}$ or articles related to commemorations of past unrest episodes. ${ }^{3}$ As the series $y_{i t}$ and $z_{t}$ will be used principally

\footnotetext{
${ }^{2}$ For example, excluding "protestant" which, despite having etymological roots in common with "protest," is now reserved for a specific religious meaning. We similarly omit the word "demonstration" given its multiple meanings.

${ }^{3}$ We take the list of terms from Caldara and Iacoviello (2018)
} 
to normalize the article count, we follow Jirasavetakul and Spilimbergo (2018) and add a further filter: that articles include the common and neutral term "today". 4

\begin{tabular}{llll}
\hline \hline & $x_{i t}$ & $y_{i t}$ & $z_{t}$ \\
\hline Must include & $\begin{array}{l}\text { Country name AND ("protest*" OR "riot*" OR } \\
\text { "revolution" OR (( "civil" or "domestic") within } 10 \\
\text { words of "unrest") }\end{array}$ & $\begin{array}{l}\text { Country } \\
\text { Name AND } \\
\text { "today" }\end{array}$ & "today" \\
Must exclude & $\begin{array}{l}\text { Country-specific terms OR "vote of protest" OR } \\
\text { "protest vote" OR "protestant*" OR "anniversary" }\end{array}$ & \\
& OR "war" OR "memorial" OR "movie" & & \\
Location tag & Country $i$ & Country $i$ & \\
Subject tag & Domestic Politics Or Civil Unrest & & $100+$ \\
Word count & $100+$ & $100+$ & 100 \\
\hline
\end{tabular}

Table 1: Article search Criteria

We also add restrictions on location, subject, and word count on the articles. The first two of these are implemented via category tags provided by Factiva. The location tag helps to screen some articles about civil unrest directed at a given country rather than in a given country, such as foreign-policy protests. However, this is not always successful (see section 3.4 below).

Table 2 presents key summary statistics of the data and Figure 2 shows the cross-country distributions of articles. The cross-country distribution is highly skewed. For example, although the median country is featured in an average of 116 articles per month, the average across countries is 350. The within-country skew is also very large, with the median country attaining a peak of almost 900 articles per month. In general, the relative volatility of the social unrest series $x_{i t}$ is much greater than the the country total count $y_{i t}$. For example, the median country has an average of three social unrest articles per month, but a maximum of 75 . This suggests that there is considerable scope for large movements in the data which sharply discriminate between different observations.

\subsection{Constructing the Index}

From the raw article counts, we create two indices:

$$
R S U I_{i t}^{A}=\frac{x_{i t}}{\frac{1}{12} \sum_{j=1}^{12} z_{t-j}} \times \frac{100}{\bar{x}_{i} / \bar{z}} \quad \quad R S U I_{i t}^{B}=\frac{x_{i t}}{\frac{1}{12} \sum_{j=1}^{12} y_{i, t-j}}
$$

\footnotetext{
${ }^{4}$ This is very slightly inconsistent: we include the words "today" in the normalizers $y_{i t}$ and $z_{t}$ but not in the main article count $x_{i t}$. Yet both the obvious alternatives are worse. As blank search strings are not valid Factiva search queries, we cannot omit "today" from the normalizers. And social unrest articles are sufficiently few that we cannot omit those which happen report on unrest in the preceding few days. Given a menu of flawed choices, we choose to be approximately right rather than precisely wrong.
} 


\begin{tabular}{lrrrr}
\hline \hline & Median & Mean & 10th percentile & 90th percentile \\
\hline Social unrest articles, $x_{i t}$ & & & & \\
Within-country mean & 3 & 8 & 1 & 22 \\
Within-country max & 74 & 183 & 18 & 434 \\
Contemporaneous country articles, $y_{i t}$ & & & & \\
Within-country mean & 117 & 360 & 24 & 803 \\
Within-country max & 918 & 2302 & 257 & 5342 \\
\hline
\end{tabular}

Table 2: Monthly article counts, summary statistics

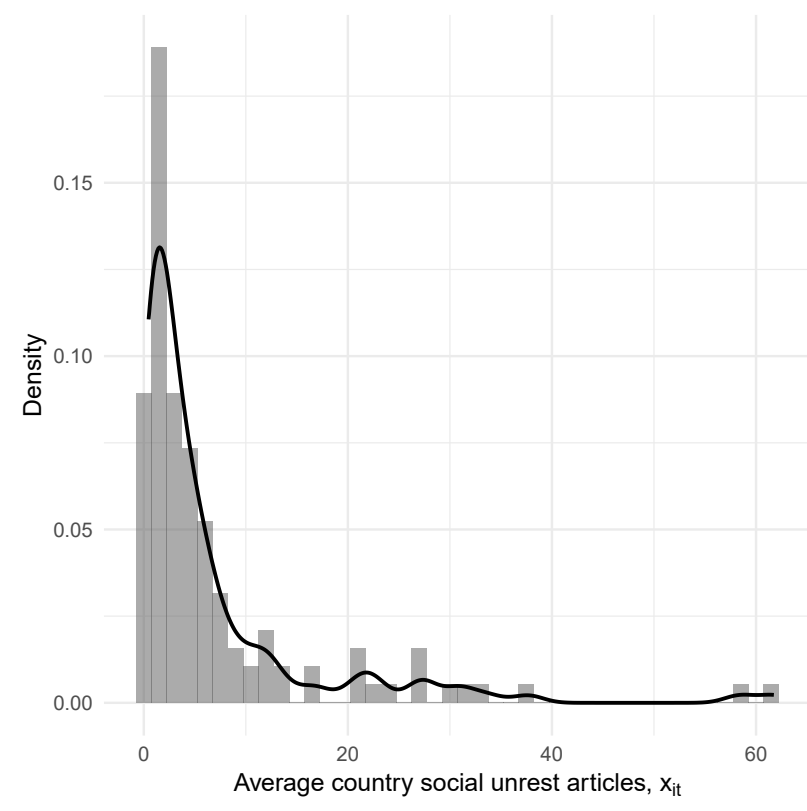

(a) Social unrest articles, $x_{i t}$

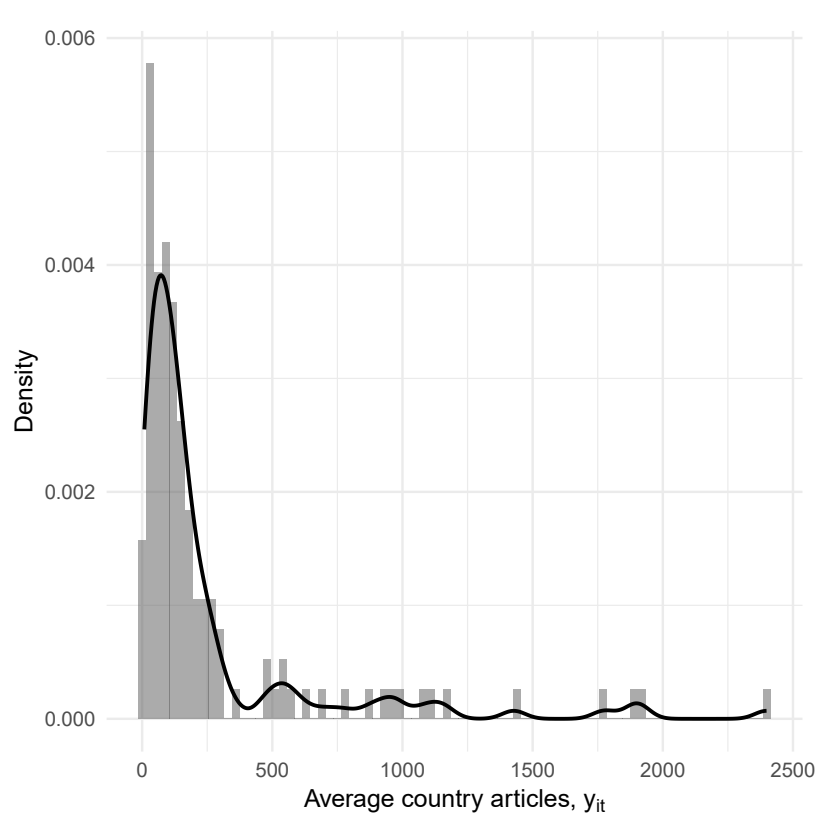

(b) Contemporary country articles, $y_{i t}$

Figure 2: Cross-country average monthly article counts

Where $\bar{x}_{i}$ and $\bar{z}$ are the (country $i$ ) averages of $x_{i t}$ and $z_{t}$ respectively over all time periods. That is:

$$
\bar{x}_{i}=\frac{1}{T} \sum_{t=1}^{T} x_{i t} \quad \bar{z}=\frac{1}{T} \sum_{t=1}^{T} z_{t}
$$

We call the two RSUI measures, unsurprisingly, the A index and the B index. These two indices have complementary strengths and weaknesses. The advantage of the B index over the A index is that it has naturally interpretable units - it is the share of contemporary articles in a given country about social unrest. In contrast, the A index uses the fraction of all articles which are about unrest in country $i$. This makes cross-country comparisons difficult using the A index, as a given country may receive more coverage from our sources on average for reasons unrelated to social unrest, such as size, proximity, or common historical or cultural ties. To emphasize this point, we define the A index as being rebased to have mean 100. Of course, scaling by average total country coverage should correct for this, as average interest in country $i$ affects both numerator and denominator. 
Indeed, this is exactly what we do when constructing the B index. Yet this approach fails, as we discuss next.

The B index suffers from two flaws which mean that we chose the A index as our primary measure. First, many countries have very little coverage outside of social unrest events. And so the denominator $\frac{1}{12} \sum_{j=1}^{12} z_{i, t-j}$ is often very close to zero, vastly amplifying any noise in the numerator, $x_{i t}$. Second, coverage of a given country is often endogenous to social unrest or recent social unrest. Coverage of a given country in general will likely respond to social unrest, as journalists follow up on the consequences of major unrest. While the one-period lag in the denominator (as $j$ runs from 1 to 12 not 0 to 11) can help address contemporaneous endogeneity, this is insufficient for major events where interest may run high for several months.

In contrast, the A index suffers from neither of these drawbacks, and so we use it as our headline measure, presented as an index scaled to a mean of 100 within each country. However, because this measure contains no useful cross-country information, we will will also use the B index as a filter for false positives when coding events in Section 3.3.

Figure 3 shows the A and B measures for a sample of six Middle Eastern countries during and after the Arab Uprisings of 2011, scaled to average to 100 over the whole sample. This illustrates two important points. First, the behavior of the index appears to be characterized by large intermittent spikes. This motivates our secondary characterization of the series in terms of major unrest events in the next section. Looking forward slightly, this Figure includes the events and labels that we derive using the methodology in Section 3.3. The purpose at this point is not yet to explain the event coding in detail but instead simply to use a well-known episode of unrest to introduce the series and discuss the relative merits of the $\mathrm{A}$ and $\mathrm{B}$ indices.

The second point this figure highlights is the endogeneity problem for the B index, in that it appears to understate the persistence of social unrest. Major spikes in the A index during 2011 and early 2012, such as the Tahrir Square protests in Egypt and the Tunisian Parliamentary elections of 2011, are almost invisible when using the B index. This difference is entirely due to short-term changes in the divisor of the B index. Because coverage of the country as a whole also rises following social unrest events, the denominator series $y_{i t}$ increases, pulling down the B index and resulting in its failure to capture secondary unrest events. This means that the B index will badly mis-state the persistence and predictability of social unrest events, meaning that it is not suitable as a primary measure of social unrest. Accordingly, all subsequent charts and references to the RSUI are used to refer to the A index only.

\section{$3.3 \quad$ Events}

We define a social unrest event as a period $i$ in a country $t$ matching three criteria:

1. The A index is a local peak: $R S U I_{i t}^{A}>\max \left(R S U I_{i, t-1}^{A}, R S U I_{i, t+1}^{A}\right)$.

2. The A index satisfies at least one of the following extremum criteria:

(a) $R S U I_{i t}^{A}$ is in the top $2 \%$ of observations for country $i$; 


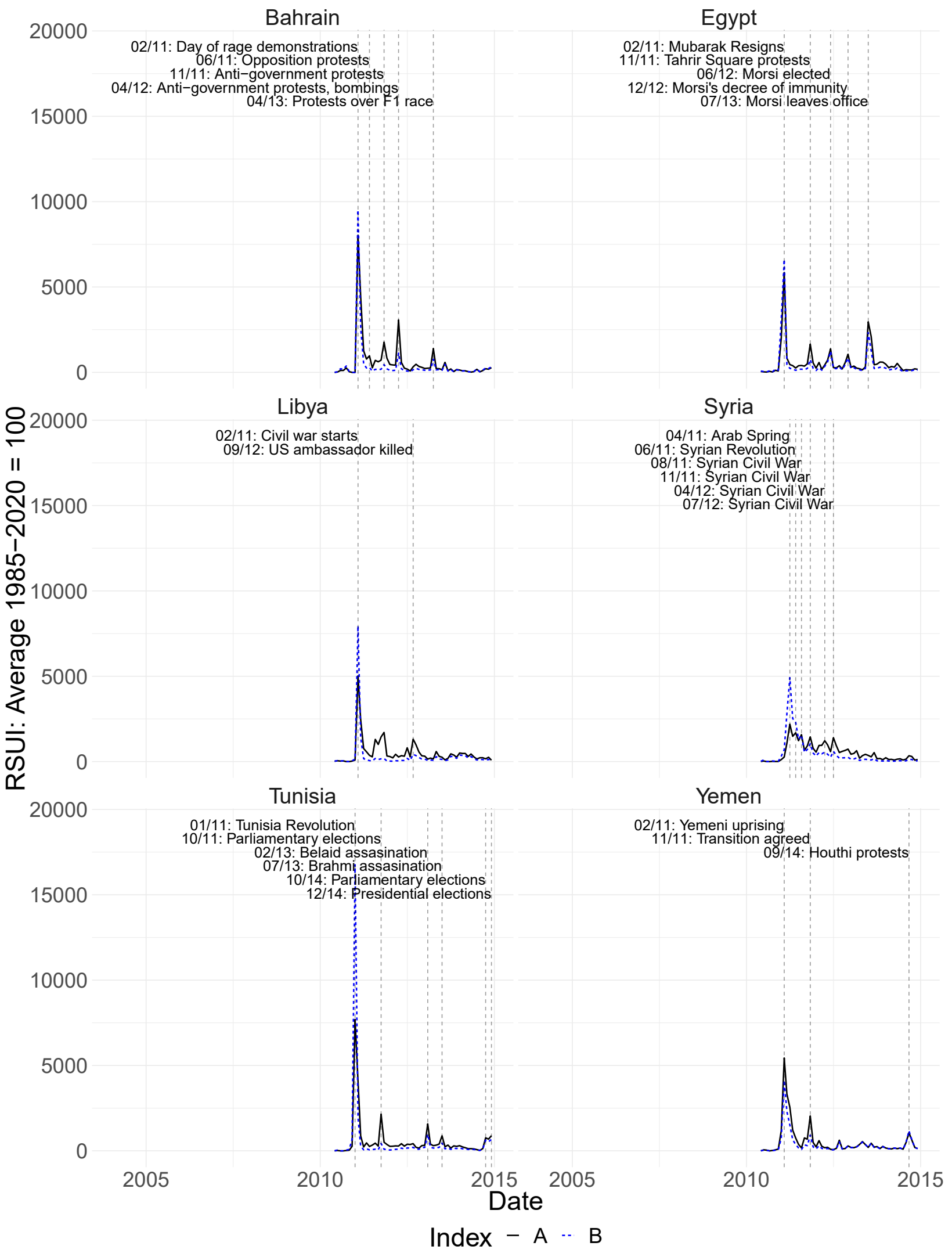

Figure 3: Arab uprisings, June 2010 - December 2014: Major events identified from RSUI event coding 
(b) $R S U I_{i t}^{A}$ exceeds the mean for country $i$ by at least four times the standard deviation for country $i$;

(c) RSU I $I_{i t}^{A}$ exceeds the rolling 20-year mean for country $i$ by at least four times the rolling 20-year standard deviation for country $i$.

3. The B index exceeds $0.1, R S U I_{i t}^{B}>0.1$

Each of these criteria aims to select or exclude particular types of events. The first two conditions aim to select unusually high values of the RSUI relative to the distribution of within-country outcomes. By including both a percentile and a standard deviation threshold we aim to ensure that the event coding is robust to cross-country variation in distribution of the A index. The inclusion of part c) addresses the possibility of changing media focus over time and means that we still identify events consistently even if a given level of unrest in a given country becomes more or less interesting to our sources over time. ${ }^{5}$ The design of conditions 1 and 2 also strips out much cross-country variation in media bias when coding events. Because they are entirely relative measures, they will identify exactly the same set of events whether the outlets we use are highly focused on a given country or pay it little attention.

Because they depend on the full distribution of within-country outcomes, conditions 1 and 2 work well when there are at least a few major social unrest events within a country. However, in some countries, social unrest is very rare. Yet in these cases condition 2 will still select at least 2 percent of observations as candidate events. Thus we add condition 3, which leverages the natural units of the $\mathrm{B}$ index to impose a very small amount of cross-country information. This is a sufficiently weak restriction that major events are still identified despite the flaws in the B index, yet still still acts to filter out false positives which would otherwise be produced in countries with very little social unrest.

Of course, the specifics of how series and events are computed are somewhat arbitrary. To a large extent this is inevitable; there is no way to pick thresholds and measures for extreme points which is not arbitrary. So rather than seeking to defend these choices a priori, we instead justify them by their results. We turn to this in section 4 , where we carefully assess the index and events against authoritative external sources for three major episodes of protest.

This methodology identifies some [679] monthly events, summarized in Figure 4, which shows the fraction of countries with social unrest events by region. One can clearly see several regional waves of protest. In the late 1980s, a number of events in South and Central America and the Caribbean drive the spike in events in the Western Hemisphere, including the democratic transition in 1986 in Guatemala, attacks on voters in the Haitian elections of 1987, the Chilean Plebiscite of 1988, the 1989 Paraguayan Coup d'état, and the 1990 Nicaraguan elections which ended the Sadanista regime. The fall of communism is reflected in an increase in the European series in the early 1990s

\footnotetext{
${ }^{5}$ This has an important impact early in the sample where major world events (e.g. end of Apartheid, fall of the Iron Curtain) show as smaller peaks in the A index than much less dramatic later events. This is consistent with globalization increasing demand for foreign news as consumers become more aware of and more connected to overseas events.
} 


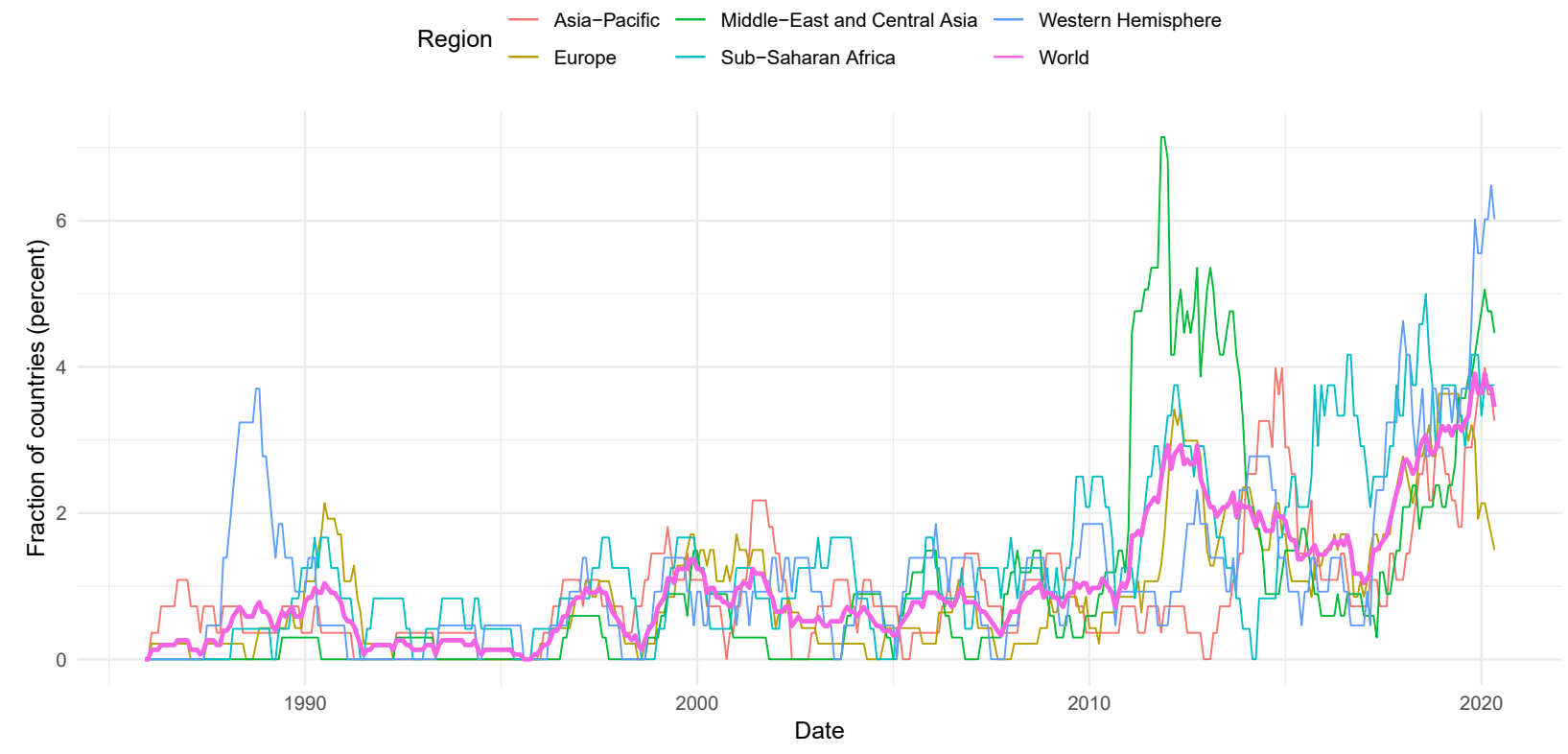

Figure 4: Fraction of countries with social unrest events, 12 month moving average

due to events in Bulgaria, Czechoslovakia, Germany, Poland, Romania, and the Baltic countries. ${ }^{6}$ The largest recent wave of events is in the Arab Uprisings of 2011, which are clearly seen, driven by events across almost the whole Middle East (shown for six countries with event labels in Figure 3 ), as well as a simultaneous wave of anti-austerity protests in Europe. More recent protests in Bolivia, Chile, Colombia, Ecuador, and Peru contribute to a spike in unrest events in late 2019 and early 2020.

\subsection{Event Screening}

Other studies using measures of media attention often run extensive checks on the matching articles that they generate (see, for example, Baker et al. (2016)). This provides a valuable screen to assess the validity of the results. Instead of checking every month for every country by hand, we check only the events identified using the methodology of the preceding section. For each event, we check the matching articles in Factiva to 1) verify that events are not egregiously mis-identified, and 2) generate a label for each event. While the event dates are coded systematically, the labels are purely descriptive, aiming to provide a little narrative color to large movements in the RSUI. Note in particular that the label descriptions do not endorse a particular interpretation of historical events.

Mis-identified events do occur, for five main reasons. First, because events relating to a given country occur elsewhere. For instance, January 2019 protests in Greece over the name of North Macedonia are labeled as occurring in the latter. Second, because past social unrest events may

\footnotetext{
${ }^{6}$ That such a momentous event triggers such a small increase relative to the Western Hemisphere is simply because there are many more countries in Europe that meet the population and search requirements than in the Western Hemisphere (39 vs. 19).
} 
be relevant context to a current event and therefore much-mentioned. For example, elections in Armenia in September 2018 followed mass protests in April. Accordingly, articles in September 2018 mention these protests even though they are not contemporaneous. Third, because the general search terms match certain country-specific features. For example, many Iranian institutions include the phrase "Islamic Revolution," and so match the civil unrest search term "revolution." Fourth, sometimes alternate usages of the search terms pollute the results - for example, elections in Denmark in 1987 for "Tax protest" parties. And fifth, occasional diplomatic events or disputes can result in events being misidentified. One such example was a diplomatic dispute in June 2014 between the Slovenian and Croatian governments over the possible entry of a Croatian patrol boat into Slovenian waters, where diplomatic interactions are described as "protest."

We identify some [100] events where articles made no specific mention of contemporaneous civil unrest events (see Table 3) and follow a two-step strategy to address mis-identified events. We start by making the smallest country-specific changes we can to the search criteria to exclude articles related to reduce mis-identification. However, this is not always possible. For example, removing references to specific past unrest events will suppress the earlier event. So in some cases, we flag mis-labeled events by hand (less than one-third of the mis-identified events) and exclude them from the set of event individually (see Table 3 ).

\begin{tabular}{lrrr}
\hline \hline & Total & Removed by search adjustment & Removed by hand \\
\hline Passed human screening & 581 & & \\
Failed human screening & 99 & 68 & 31 \\
Of which: & & & \\
Wrong country & 34 & 26 & 8 \\
Past events & 23 & 11 & 12 \\
Country-Specific & 17 & 15 & 2 \\
Incorrect usage & 13 & 7 & 6 \\
Diplomatic & 11 & 9 & 2 \\
Possible future event & 1 & & 1 \\
\hline
\end{tabular}

Table 3: Results of event scereening

\section{Assessing the Index}

Many of the choices we make in defining the index and events in the preceding section are to a greater or lesser extent arbitrary. Justifying these choices is a key objective of this paper. This justification relies on two exercises.

First, we show that the resultant index and event listing agrees almost exactly with authoritative narrative sources for four episodes of major unrest in diverse locations and times: the Arab Uprisings of 2011; the sequence of protests, coups, and constitutional crises in Thailand during 2006-2014; protests in Venezuela in 2015-2019; and the color revolutions of the 2000s. This exercise is the acid test for our work and is something of an end-run around questions of bias or coverage or language 
or other details. It shows that despite the many critiques one might make of it, our approach seems to work; it provides timely and accurate identification of major events in diverse countries and times. In case this evidence is insufficient, we also provide several further narrative sources in Appendix B. ${ }^{7}$

Second, we show that the results are not sensitive to the particular choices we make. We vary language, sources, and search terms and -where applicable - get very similar results for a subset of Middle Eastern Countries since 2011. We interpret this as evidence that using media reports to identify social unrest is relatively forgiving; major events are sufficiently stark and obvious that they are revealed no matter the precise details of the methodology used to identify them.

One exercise that we do not put a lot of weight on is comparing to alternate measures, such as the Cross-National Time-Series Database (CNTSD, Banks and Wilson (2020)) or The Armed Conflict Location \& Event Data Project (ACLED). This is because comparison to these alternatives is a relative test, and cannot distinguish between shortcomings of our measures and those of the alternatives themselves. For example, do differences with the CNTSD simply reflect the small number of sources used in that measure? And are differences with ACLED merely a function of that source's emphasis on conflict? In contrast, the tests we value are absolute ones. Our measure matches authoritative, external reports of social unrest and it is not unduly sensitive to small changes. ${ }^{8}$

\subsection{External Validity}

We compare the index and our event coding to four major waves of protest about which we have alternative authoritative sources. In the main text we necessarily have to summarize these sources' descriptions. To permit the skeptical reader to check our interpretation, Appendix E provides full verbatim descriptions of these events form the primary sources.

The four episodes discussed below represent a wide diversity of circumstance. They vary widely by location and time period; some are country-specific and others are region-wide; the types of government vary widely from vibrant democracies to more repressive regimes; and some result in major political changes and others do not. Yet across all of them, the index and the implied events match up very closely with alternate narrative sources.

\subsubsection{The Arab Uprisings of 2011}

For the Arab Uprisings of 2011, we take as our primary external source Worth (2016). This booklength account, written by a former New York Times journalist, is a comprehensive summary of the events and causes of the Arab Uprisings between June 2010 and December 2014, and is commonly cited as an overview reference on the subject. Most relevant for our purposes, this source includes

\footnotetext{
${ }^{7}$ These include: the "people power" revolution of 1986 in the Philippines, the pro-democracy "June struggle" in Korea in 1987, the end of apartheid in South Africa, the protests against and eventual impeachment of President Park of Korea during 2016-2017, and alternate sources on unrest in the Middle East ruing 1999-2019.

${ }^{8}$ That said, we still report comparisons to the relevant CNTS and ACLED series in Appendix C.
} 
an extended timeline with daily events in six countries: Bahrain, Egypt, Libya, Syria, Tunisia, and Yemen.

The downside of using Worth (2016) as our point of external comparison is that it is not peerreviewed. This is not by design. Despite a wide political science literature on the Arab Spring, finding a single authoritative peer-reviewed summary timeline or event listing seems to be rather difficult; we could not find one. The reasons for this are beyond the scope of the current paper, but might be that academic study of the Arab Uprisings by political scientists focuses on individual episodes rather than a comprehensive history. In Appendix B.3, we also present the details of country timelines for a slightly different set of Middle Eastern countries during January 1999 to June 2019 assembled by the United States Institute of Peace and find broad agreement between their list of events and ours.

The events identified in Worth (2016) are shown as the vertical lines in Figure 5, along with summary descriptions. ${ }^{9}$ The period and countries is identical to those in Figure 3, which includes the RSUI event codings; the two can thus be directly compared.

The most striking aspect of Figure 5 is that the cross-country timing of the initial round of protest almost exactly coincides with the initial spikes in the RSUI early 2011. The first outbreak of unrest during the Arab Uprisings were protests in Tunisia following the self-immolation on 17 December 2010 and subsequent death on 4 January 2011 of Mohamed Bouazizi. This is reflected in the large spike in the RSUI and corresponding RSUI-implied event in January $2011 .^{10}$ Prior to this there are no RSUI-implied events in any of these six countries.

The first RSUI-implied event of the Arab Uprisings in Egypt is dated to February 2011. This again agrees almost identically with the external timeline, which dates the start of protests to the last week of January and extending through February 2011. Similarly, the RSUI dates the start of the Arab uprisings for Bahrain, Libya, and Yemen to February, consistent with Worth's timing of February or very late January. And in Syria, the RSUI first picks up sharply in March, also consistent with the Worth timing. Overall, the index and event coding match the cross-country order of the start of the Arab Uprisings exactly, and the timing very closely.

Worth's timeline following the initial outbreak of unrest also lines up very closely with the index and implied events. For instance, the major turning points of the Egyptian revolution all show as index spikes and satisfy event definitions, albeit sometimes with a one-month lag when an event occurs in the second half of a month. This includes running battles for control of Tahrir Square in November 2011, the election of Muhammed Morsi and subsequent unrest in June 2012, the collapse in November 2012 of the constituent assembly to draft a new constitution following President Morsi's decree of personal immunity, and Morsi's eventual overthrow in July 2013. In Libya, Tunisia, and Yemen the major post-revolutionary events are similarly identified by the RSUI.

\footnotetext{
${ }^{9} \mathrm{~A}$ full description of the timeline with events recorded at daily frequency is reported in Table 11.

${ }^{10}$ Because the RSUI is at a monthly frequency, and because new coverage is inherently at least a little backwardlooking - events happening a few days prior may still be "news" - social unrest which begins in the second half of the month is sometime reflected in a sharp pick-up in news coverage at the start of the next month. In other words, our identification of events cannot be more precise that the frequency of the data.
} 
Bahrain

14/02/11: Protests start 14/03/11: Saudi troops arrive'

7500

5000

2500

0

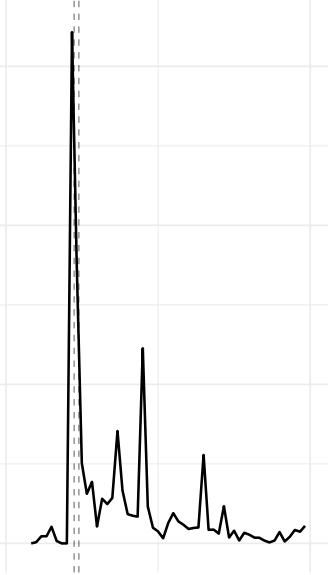

Libya

15/02/11: Large-scale Benghazi protests" 27/02/11: Transitional Council is formed

17/03/11: UN authorizes air strikes 20/08/11: Qaddafi killed

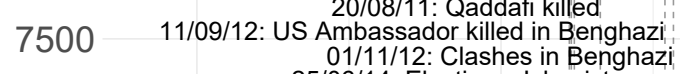
25/06/14: Elections; Islamist coup in Tripoli

$\overline{\mathscr{\varpi}}^{5000}$

2500

0

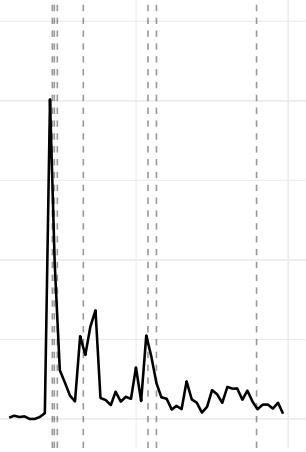

Tunisia

17/12/10: Bouazizi self-immolation" 14/01/11: Ben Ali resigns' 23/10/11: Parliamentary elections

25/07/13: Mohamed Brahmi'assassinated

7500 28/09/13: Ennahda movement agrees to cede poweir
Egypt

25/01/11: Protests start" 28/01/11: Protestors take Tahrir Square
11/02/11: Mubarak resigns
19/03/11
: Constitutional referendum 28/01/11: Protestors take Tahrir Square
11/02/11: Mubarak resigns
19/03/11
. Constitutional referendum 19/03/11: Constitutional referendum 01/06/12: Morsi elected president 30/06/12: Anti-Morsi protests 14/08/12: Rabaa square 'cleared

01/11/12: Morsi decree grants him broad powers 03/07/13: Morsi deposed 30/03/14: Sisi Elected president

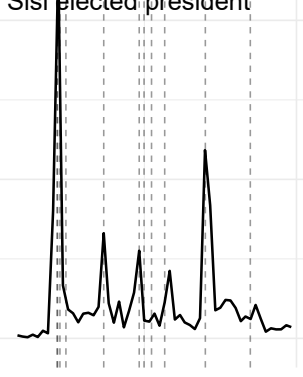

Syria

15/03/11: Demonstrations start in Syria'

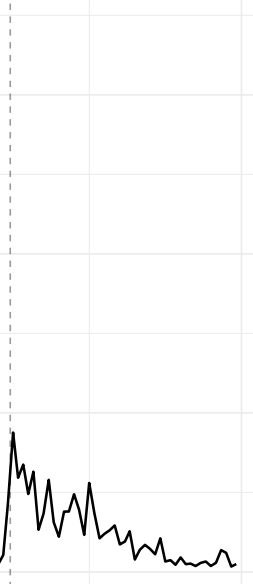

Yemen

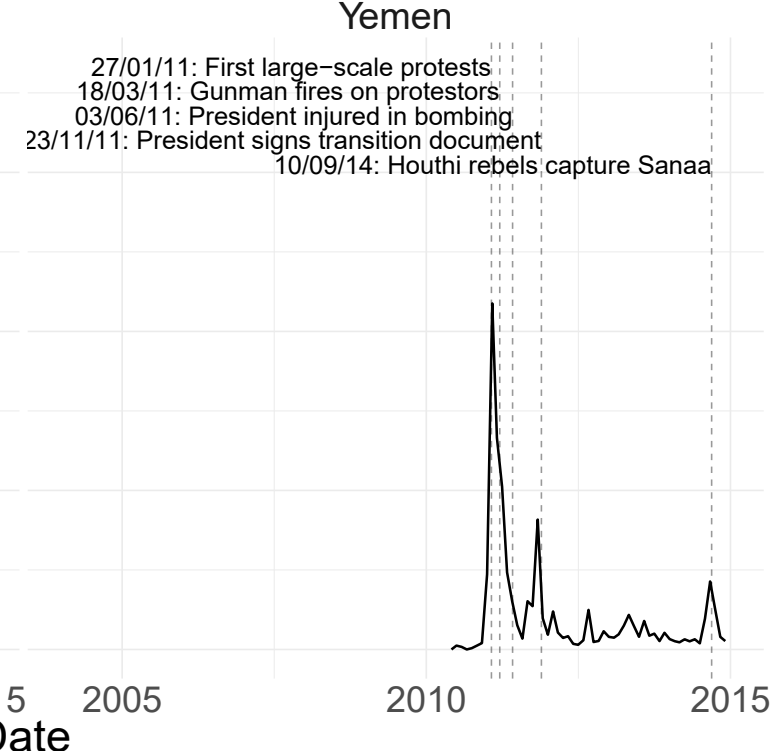

Figure 5: Arab uprisings, June 2010 - December 2014: Countries with major events identified by Worth (2016) 
There are only two major difference between the RSUI events and the Worth timeline, both of which are easily explained. The first is that the RSUI distinguishes separately the deaths of Tunisian politicians Chokri Belaid and Mohamed Brahmi, which Worth mentions together only following the death of the latter. The second major difference is for Bahrain in April 2012 when a bomb blast injured several policemen and the Bahrain Grand Prix was subject to domestic protest. These are arguably both major unrest events and so their inclusion does not seem unreasonable.

\subsubsection{Thailand 2006-2014}

The second narrative case study we look at is the series of related protests, coups, and constitutional crises in Thailand between 2006 and 2014. Our narrative sources are a series of annual synopses of Thai current events published in a peer-reviewed political science journal - Prasirtsuk (2009, 2010, 2015) and Dalpino (2011) - as well as two further papers from the Asian Studies literature, one published in a peer-reviewed journal - Baker (2016) - and one an institutional working paper, Keyes (2006). From these, we identify the timing of key unrest events. Verbatim extracts are reproduced in Appendix E.

Following a landslide re-election in 2005, anti-government protests erupted in January 2006 following revelations that the Prime Minister's family had benefited from the tax-exempt sale of assets. In late February, snap elections were announced, although protests continued until the elections themselves in April. These events are reflected in a sharp spike in the RSUI in February and March 2006, corresponding to the peak of the protests. The results of the election were disputed, leading to a political vacuum which was resolved only by a military coup in September, reflected by a second spike in the RSUI in the same month (see Figure 6).

The events of 2006 set the stage for further unrest in 2008-2010. Military power ended and elections were held in late 2007, bringing allies of the now-exiled Prime Minister to power. His return in February prompted further political disputes, culminating in violent clashes in Bangkok between the "yellow" and "red" shirt factions (in September) and the takeover of two major airports by protestors (in November). These are reflected in peaks in the RSUI in the corresponding months.

Following a change in government in December 2008, protestors held major anti-government demonstrations in April 2009 in Bangkok. This coincided with a major regional summit (ASEAN) in nearby Pattaya and led to its cancellation and a further local peak spike in the RSUI.

After a Supreme Court ruling validating the seizure of the former Prime Minister's assets, massive anti-government protests again broke out in March 2010. By April, the ongoing protests had turned violent, with the new Prime Minister declaring a state of emergency as anti-government protestors occupied parts of the city. In May, efforts by the army to re-establish control were accompanied by widespread disorder and several fires, including the burning of the Stock Exchange of Thailand and a major department store. Dozens died, including protestors, army officers, and

an Italian journalist. The RSUI reflects the depth of the crisis at this point, with very high values in April and May.

Several years of relative calm followed and the transfer of power in 2011 to a government 
led by ex-Prime Minister's sister prompted relatively little unrest, at least by the standards of preceding years. Yet the introduction of a bill in October 2013 providing amnesty for protestors and politicians upset the delicate balance of power and led to mass anti-government demonstrations in November. Unrest dissipated in December around public celebrations for the King's birthday. But anti-government protests once again broke out in January, as opposition parties demanded reforms prior to the February elections. The elections went ahead as scheduled but the results were disputed and the returning Prime Minister ousted by the constitutional court, prompting a constitutional crisis. This was resolved in May when the military announced the imposition of martial law and, two days later, a coup ousted the civilian government. These events are closely matched by spikes in the RSUI in November 2013 (amnesty law protests), January 2014 (pre-election protests), and May 2014 (military coup).

Overall, the external narrative accounts of events in Thailand during this period line up very closely with the RSUI. The RSUI event-coding procedure identifies seven events in this period, corresponding closely to the narrative evidence discussed above. The events of 2006 do not register as RSUI-identified events, as later events received much more coverage, reflecting their increased severity and more frequent violence.

\subsubsection{Venezuela 2014-2019}

Following the presidential election of April 2013, Venezuela experienced several major waves of protests as opposition forces attempted to oust him from office. We use Gutiérrez (2017) and Briceño-Ruiz (2019) as alternate narrative sources for this period. Both sources are published in a peer-reviewed Latin American political science journal. Between them, these papers document the major events events during 2013-2019, several of which include to major social unrest events.

The first peak in the RSUI in this period corresponds to the first major wave of anti-government protests in February 2014. At the time, it was not obvious that the new President had the full support of a government dominated by supporters of the previous president, Hugo Chavez, and these protests - coded as an RSUI event - were a serious threat to the incumbent president. This is verified by the alternate narrative sources, which date major protests to February 2014 as well.

During 2015 and 2016, the RSUI remains at lower levels, with no implied events, and a small peak around the opposition's parliamentary victories in late 2015. This also agrees with the narrative source. The events they record between mid-2014 and mid-2016 are all important political events, but no major protests or other civil disruptions. This changes in April 2017, when the RSUI picks up sharply and remains elevated until August. This agrees almost exactly with the description in Briceño-Ruiz (2019) who reports "a new wave of protests from April to August 2017". That the RSUI can pick up an elevated period of protest such as this suggests that media "protest fatigue" is not a major source of bias in the index.

The final series of spikes for the RSUI in this period is in January 2019, when a constitutional crisis resulted in a power struggle and widespread protests, prompting a humanitarian crisis. These events are reflected both in the narrative descriptions and in RSUI-implied event for January 2019. 


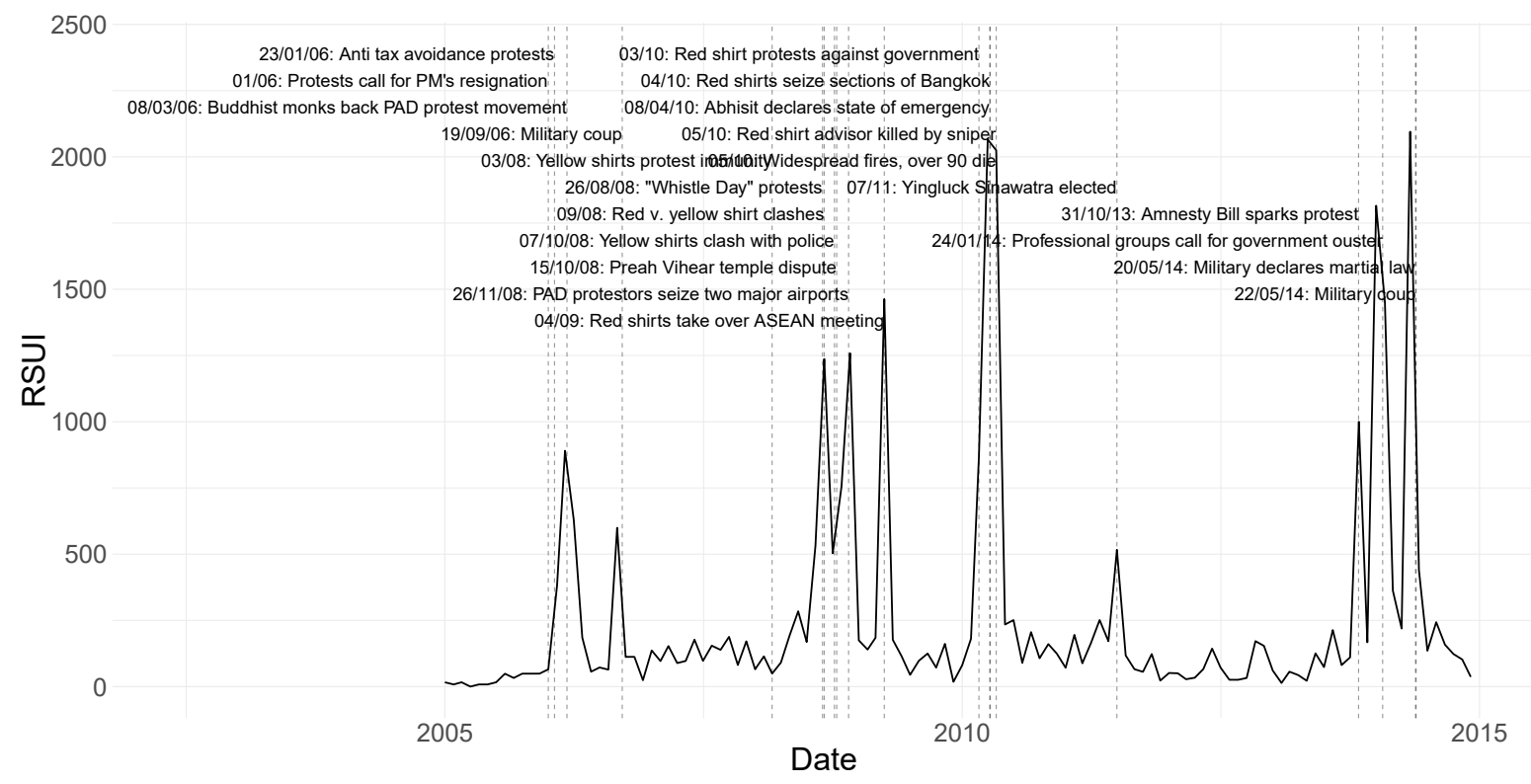

Figure 6: Thailand: Major events identified from external sources, January 2005-December 2014

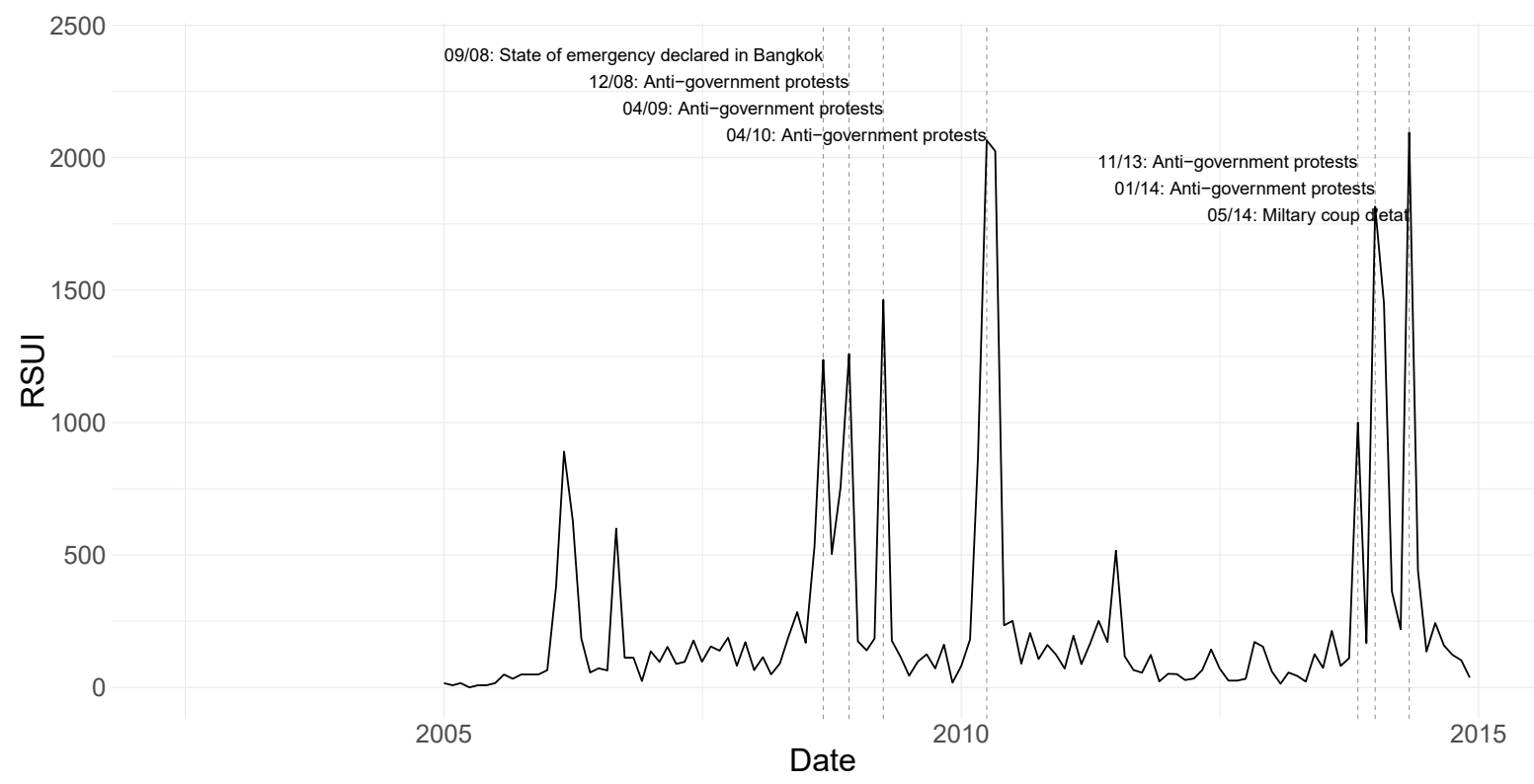

Figure 7: Thailand: Major events identified from RSUI event coding, January 2005-December 2014 
The narrative sources stop at this point. However, it is worth noting a further successful event identification of the RSUI in May of the same year, when a failed military uprising is reflected in another RSUI peak and an associated event.

Overall, the events in Venezuela line up very closely with those described in two peer-reviewed articles which include narrative descriptions of this period.

\subsubsection{Color Revolutions}

The color revolutions were a series of non-violent mass participation pro-democracy movements in former communist countries during the early 2000s resulting in the displacement of previous, often long-standing rulers. The term "color revolutions" refers to the fact that many protests were associated with particular colors, such as orange in Ukraine. ${ }^{11}$

Our external source for comparison is Tucker (2007), a peer-reviewed publication of the American Political Science Association, which focuses on the four most prominent color revolutions: Yugoslavia's "Bulldozer revolution" in October 2000; ${ }^{12}$ Georgia's 2003 "Rose revolution"; the 2004 "Orange revolution" in Ukraine; and the 2005 "Tulip revolution" in Kyrgyz Republic. In comparing these four episodes, Tucker provides a narrative description of each with key events listed by day.

Figures 10 and 11 present the RSUI and event coding for these countries during 2000-2005. In all four cases, the event coding identifies exactly the month of each of the four color revolutions. Secondary events following the main revolutionary episodes are also associated with spikes in the RSUI in Georgia and Kyrgyz Republic, in both cases delayed elections. That the event coding is somewhat conservative here is a manifestation of the trade-off between false positives and false negatives. Identifying more minor follow-up events would come at the cost of introducing erroneous events at other times in the sample.

\subsection{Internal Validity}

In this section we report several results from several alternative measures of the RSUI, where we vary a number of parameters which define the RSUI, including language, sources, and search terms.

\footnotetext{
${ }^{11}$ There is no official definition of this term and it is also sometimes applied to a much wider set of events, includes the Lebanese "Cedar" revolution of 2005 and Armenia's "Velvet" revolution of 2018 (not to be confused with the 1989 Velvet revolution which marked the end of Communist rule in Czechoslovakia).

${ }^{12}$ As does any national time series for any country which changes name or form, the subsequent dissolution of the Federal Republic of Yugoslavia poses some challenges to our categorization. Rather than creating separate searches and time series each time a new country is formed, we simply take the current description of IMF member countries as fixed and produce historical time series using the appropriate search criteria. This seems particularly apposite in our case, as one might expect social unrest and realignment of sovereigns to be highly correlated. Changing definitions would, for example, preclude our ability to identify protest event in the Baltic states prior to the dissolution of the Soviet Union. Accordingly, we proxy for events in the then-Yugoslavia using the time series for Serbia, as this is not only the largest constituent state of the Federal Republic, but also the location of the capital Belgrade and scene of the majority of the protests. That this is still successful in dating the events of late 2000 we interpret as evidence of the success of our methodology.
} 


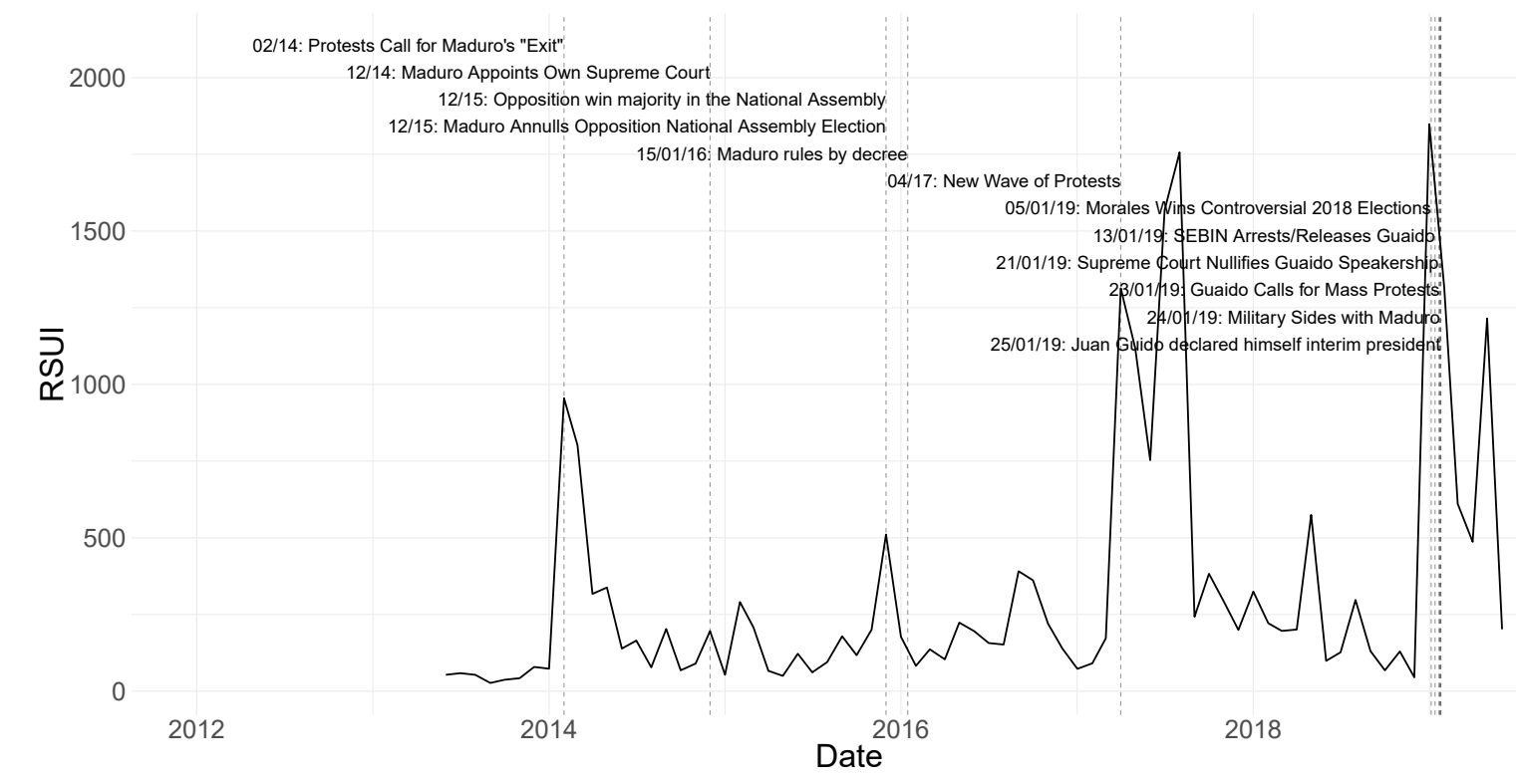

Figure 8: Venezuela: Major events identified by Gutierrez (2017) and Briceño-Ruiz (2019), January 2013-June 2019

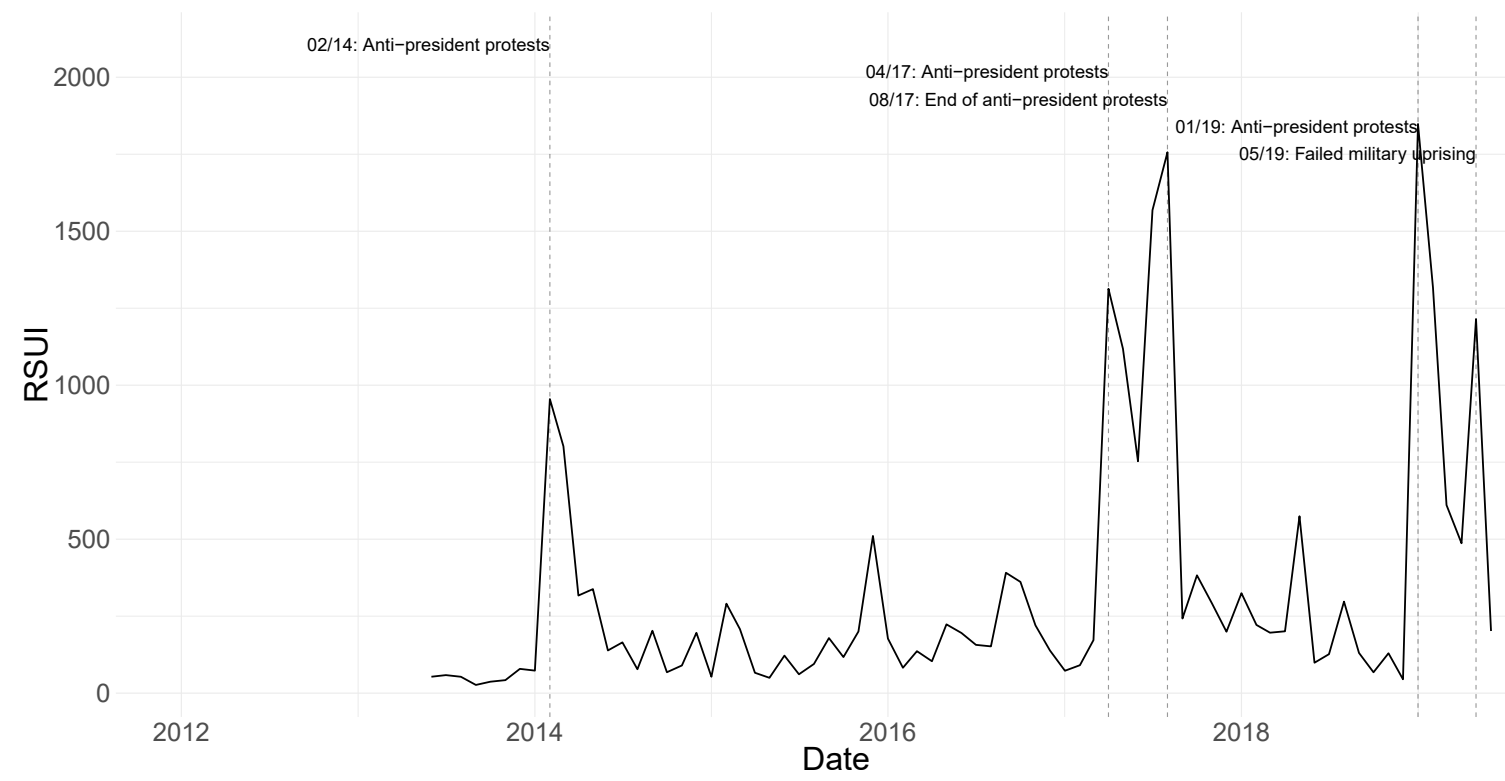

Figure 9: Venezuela: Major events identified from RSUI event coding, January 2013-June 2019 


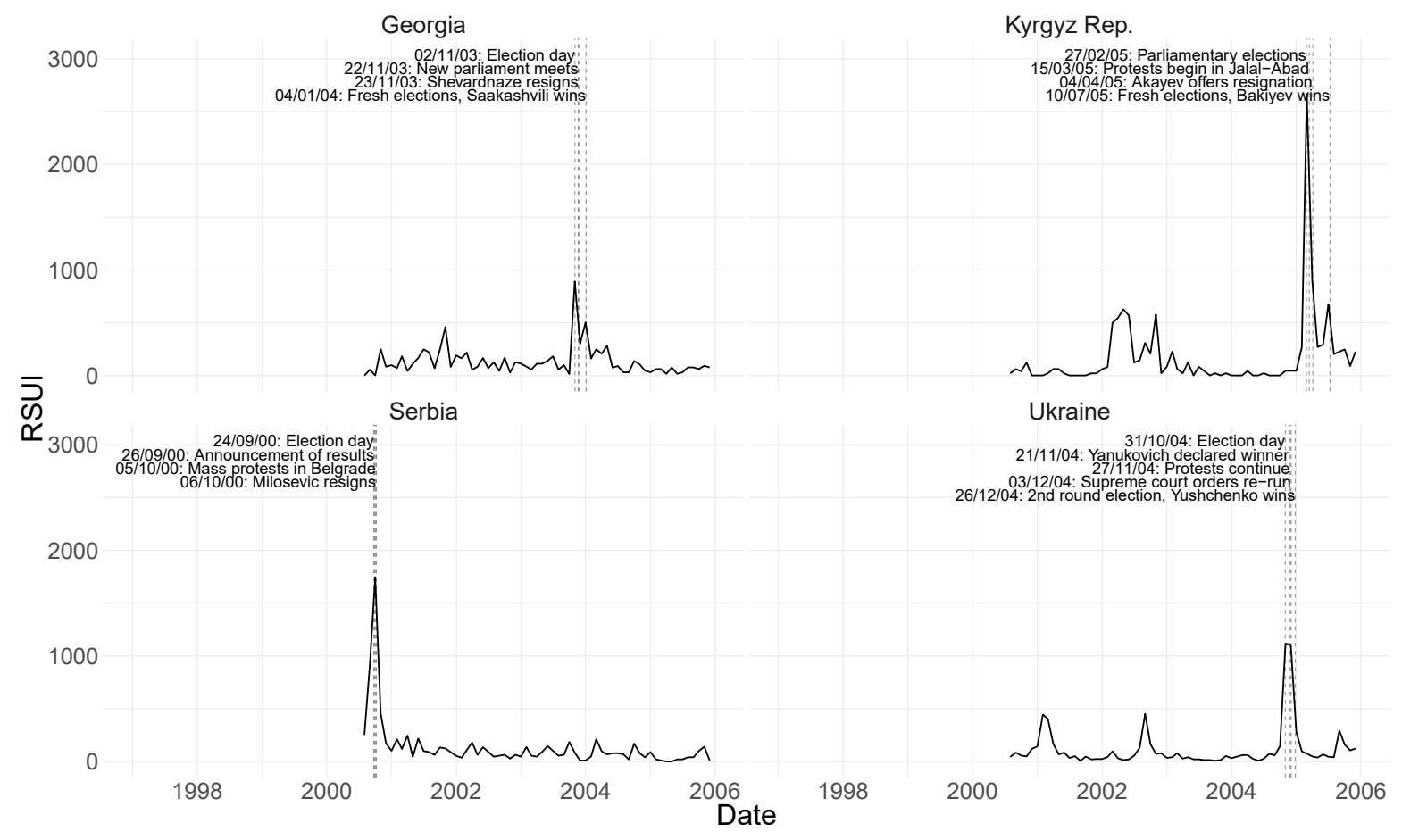

Figure 10: Color Revolutions: Major events identified by Tucker (2007), August 2000-December 2005

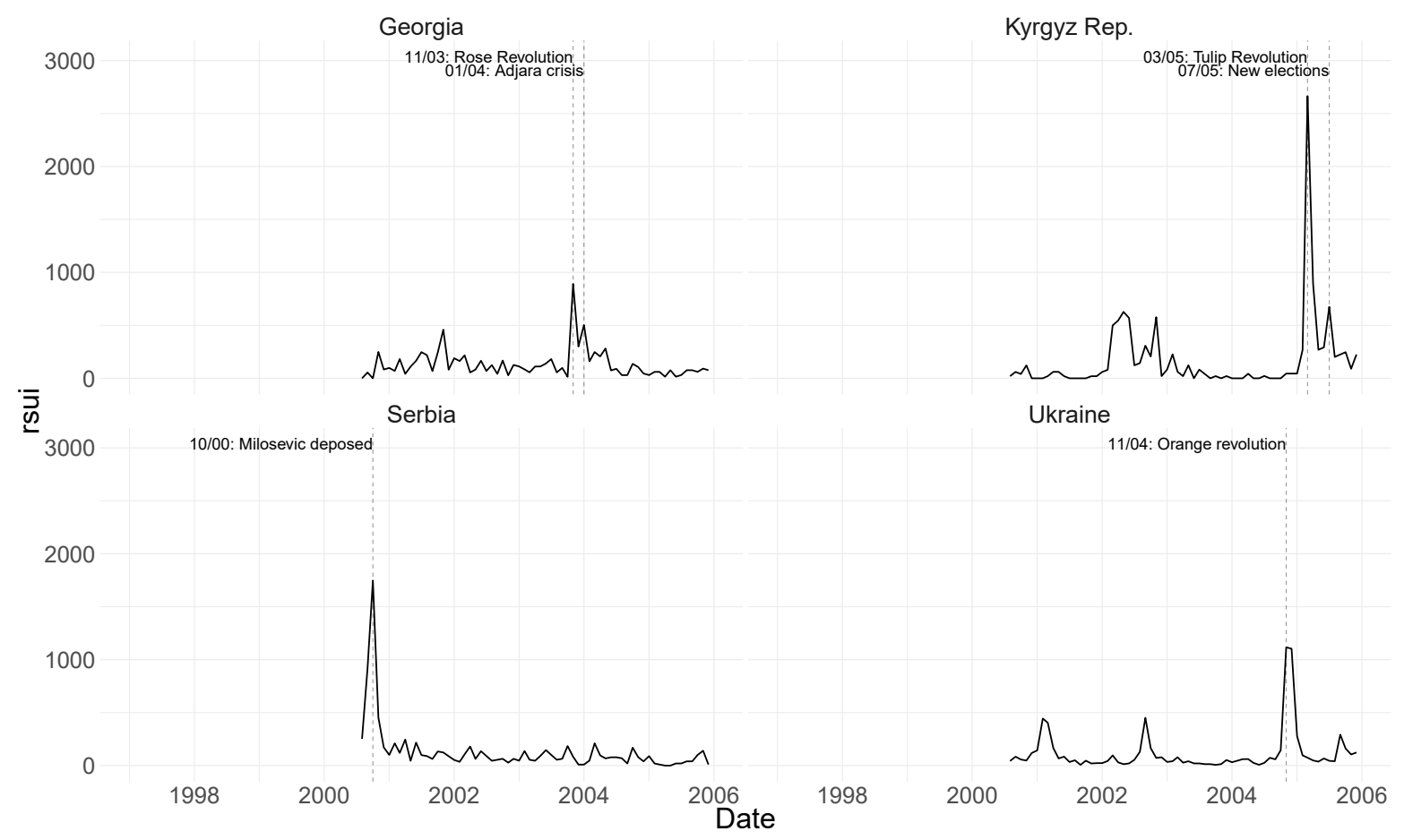

Figure 11: Color Revolutions: Major events identified from RSUI event coding, August 2000December 2005 


\subsubsection{Sensitivity to language}

To examine the hypothesis that regional and country-specific media might have different biases or could identify major social unrest events faster than western leading English-language media outlets, we recalculate the RSUI for a subset of Middle Eastern and North African countries using searches in French and Arabic. Arabic is, of course, the predominant language in the region and French - due to lengthy historical and cultural connections - is widely spoken in several countries. Naturally, this requires a different set of sources. For French, we used leading newspaper as well as newswire agencies in French: Le Figaro, Le Monde, Libération, Agence France Presse, Reuters, The Associated Press and The Canadian Press.

In Arabic, restricting our sample to only well-known international news sources did not provide wide enough coverage through Factiva to generate useful indices, with only a handful of articles available from major Arabic-language publications and a very low match rate to social unrest terms. ${ }^{13}$ We therefore cast a much wider net when defining our Arabic sources, allowing all search hits from all sources. This increases the number of articles available but the cost of a more varied set of sources, including news websites, blogs and less well-regarded outlets.

The French and Arabic search terms are reported in Table 9 in Appendix A.

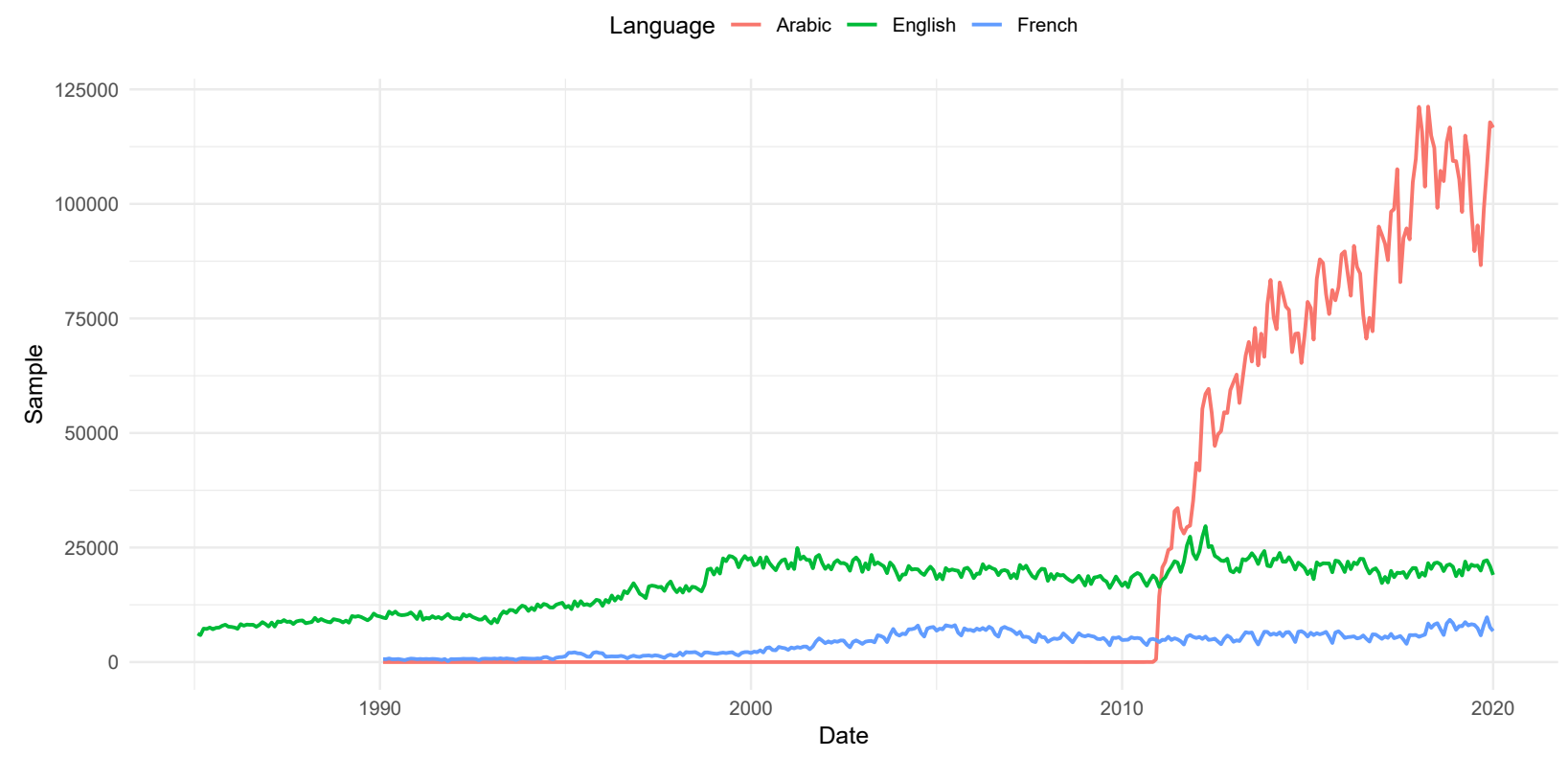

Figure 12: Number of contemporary articles per month, $z_{t}$, by language

Figure 12 reports the coverage of three datasets by language as measured by the number of contemporary articles, $z_{t}$, from which a key difficulty is immediately apparent: French language coverage is limited throughout and Arabic language content grows rapidly following 2011.

\footnotetext{
${ }^{13}$ This could be a property of the sources - that reporting on unrest is either uninteresting or dangerous for publishers. Or it could be that text-matching methods which work well in English simply do not translate well to Arabic.
} 
Figure 13 presents the A index for six Middle Eastern and North African countries where French is either widely spoken or with close historical or cultural ties to France. The major spikes are in exactly the same months for Algeria, Lebanon, Syria, and Tunisia. For Morocco there is some disagreement, but this is mostly during relatively quiet periods; major events such as the Arab Spring and the Hirak Rif protests of late 2016 and early 2017 show up clearly in both languages. Mauritania shows some differences but this is likely a function of the very small number of articles in French, with on average less than one article per month.

Figure 14 presents the A index for the six largest Arabic-speaking countries for both Englishand Arabic-language sources. The Arabic-language sources do a poor job of distinguishing between countries. For example, Sudan and Saudi Arabia show large spikes in early 2011 despite very limited unrest at those times (and, in the case of Sudan, a much smaller response during the overthrow of the government in April 2019). Even within countries, the timing is inconsistent with the narrative evidence presented in the preceding section, dating the start of the uprising in Egypt to November 2010 - clearly too early to be plausible.

There may be several reasons why the Arabic-language index struggles to distinguish countryspecific unrest events. One factor could be the common language itself, with the resulting close cultural connections leading to an inherently more pan-Arabic outlook and thus reporting the Uprisings as a single common occurrence rather than as a series of country-specific events. The difficulty in matching social unrest articles also undoubtedly plays a role, with the peak in November 2010 a result of just 18 matching social unrest articles (versus a February 2011 English-language peak of some 1600 articles). This means that a few incorrect matches can have an outsize impact on the index.

Overall, the comparison across languages suggests either that our headline series agrees well (with French) or that there are more fundamental limits imposed by availability of sources (in Arabic).

\subsubsection{Sensitivity to search terms}

We also explore how our results vary with the choice of search term, for two reasons. First, we want to check that our headline search is not sensitive to small changes to the search terms. Second, we want to better understand what other issues might be associated with social unrest events.

To this end, we conduct four extra searches, all derivatives of the headline search for $x_{i t}$ (see Table 4). The first two are extensions of the headline search, adding extra matches on related terms: one using a broader set of descriptions, including those related to potentially more violent outcomes (the "Expanded" search); and one which also admits a wider description of social tension rate than just unrest (the "Tension" search). The second set of extra searches are restrictions of the headline search, highlighting two of the key factors often cited as a driver of protest during the Arab Uprisings of 2011: economic underperformance and alienation of youth. ${ }^{14}$

\footnotetext{
${ }^{14}$ Other episodes of unrest may have other putative drivers. We focus on this episode simply because it is a widespread regional episode with potentially common drivers.
} 


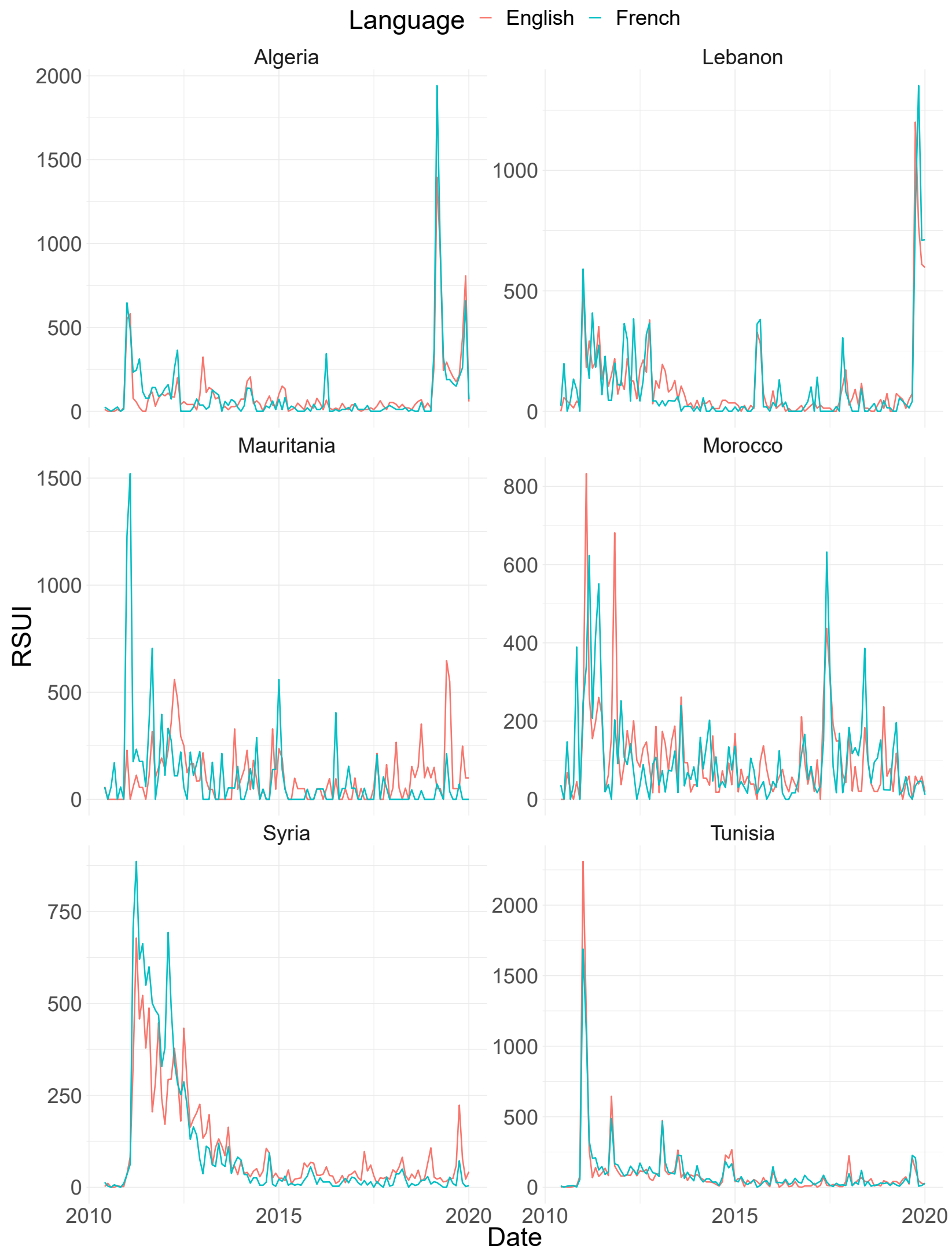

Figure 13: RSUI, June 2010 - present: Select Middle Eastern Countries with French widely spoken, by language 


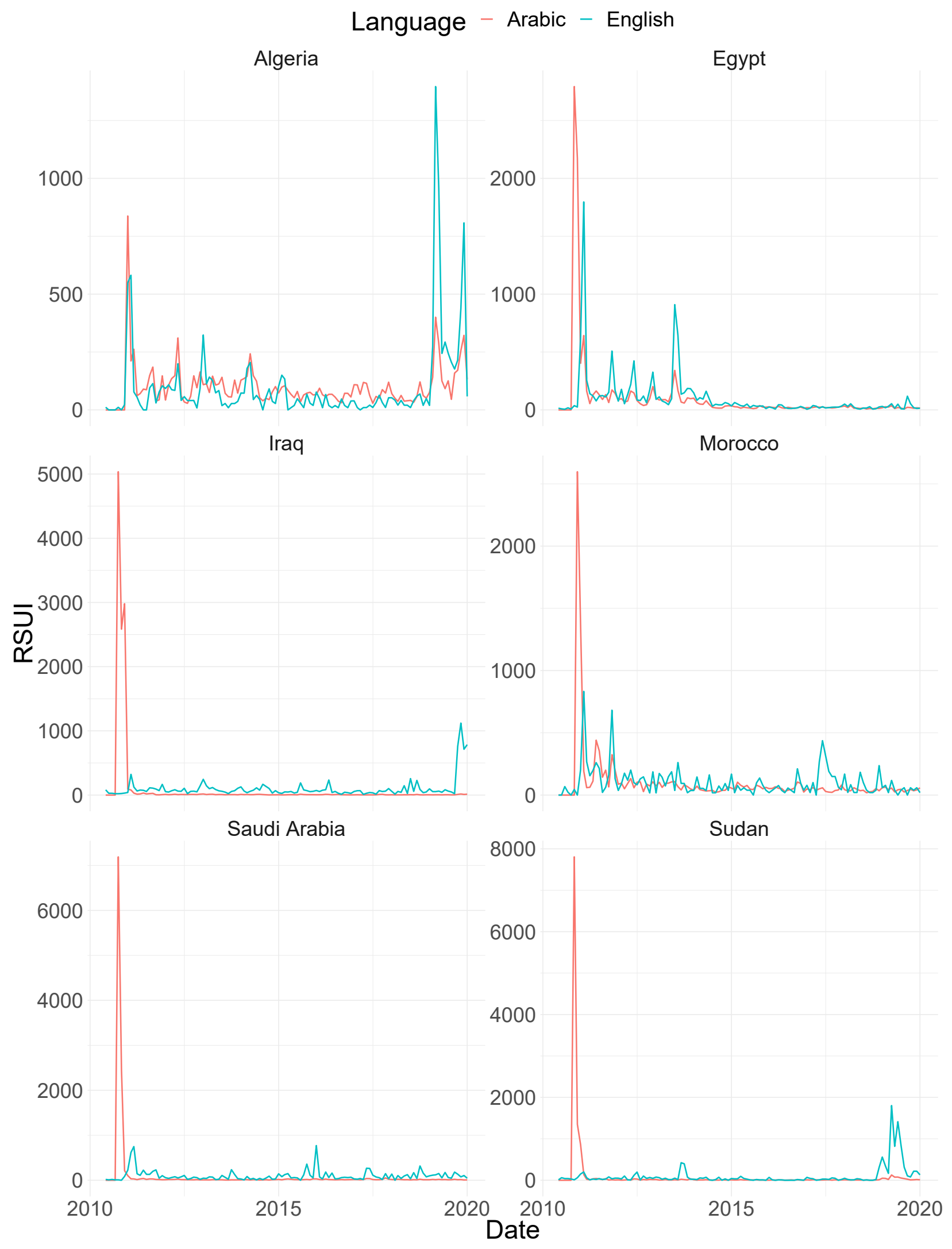

Figure 14: RSUI, June 2010 - present: Largest six Arabic-speaking countries, by language 
We conduct these searches for a sub-sample of 19 Middle East and North African countries during the sample period. The results are presented in table 5, which shows the distribution of important correlation statistics of the different measures (and Figure 15 presents the alternate indices for the same countries as in Figure 14). Given our focus on major unrest events, our preferred measure is the overlap of the largest observations, which we limit to 2 percent, but we also present standard correlation coefficients. The overlap for the extension searches is very high, with three-quarters of countries having at least 85 percent of observations in common in the top 2 percent. This suggests that the headline index is not driven by specific or spurious matches related to the particular search terms we include but is instead a broad-based indicator of the underlying discussion.

The searches restricted to include results driven by economic outcomes or youth activities also shine some light on the potential drivers of protest. In general, the largest observations of the RSUI tend to include just two key economic terms with notable frequency; in the median country, nearly four-fifths $(79 \%)$ of the largest headline matches also included a economic term, and the agreement is over half $(55 \%)$ in fully 90 percent of countries. While we cannot conclude that economic factors necessarily drove protest, this does mean that they were at least a common simultaneous topic of discussion. In contrast, terms related to young people come up much less frequently, with a common fraction of top matches in median country of only $45 \%$.

\begin{tabular}{lll}
\hline \hline Name & Type & Terms \\
\hline Expanded & Extension & "attack" OR "conflict*" OR "strike" OR "police*" \\
Tension & Extension & "attack" OR "conflict*" OR "strike" OR "police*" OR "social" within \\
& & 10 words of "tension" \\
Economic & Restriction & "econom*" OR "unemployment" \\
Youth & Restriction & "youth"
\end{tabular}

Note: Alternate searches for $x_{i t}$. All searches are derivatives of the headline search. Those labeled "Extension" include OR operators for the extra search terms, so return extra matches which may include terms listed. Those labeled "Restriction" append the listed terms using an AND operator, so return only those headline matches which also include the terms listed.

Table 4: Alternate search terms 


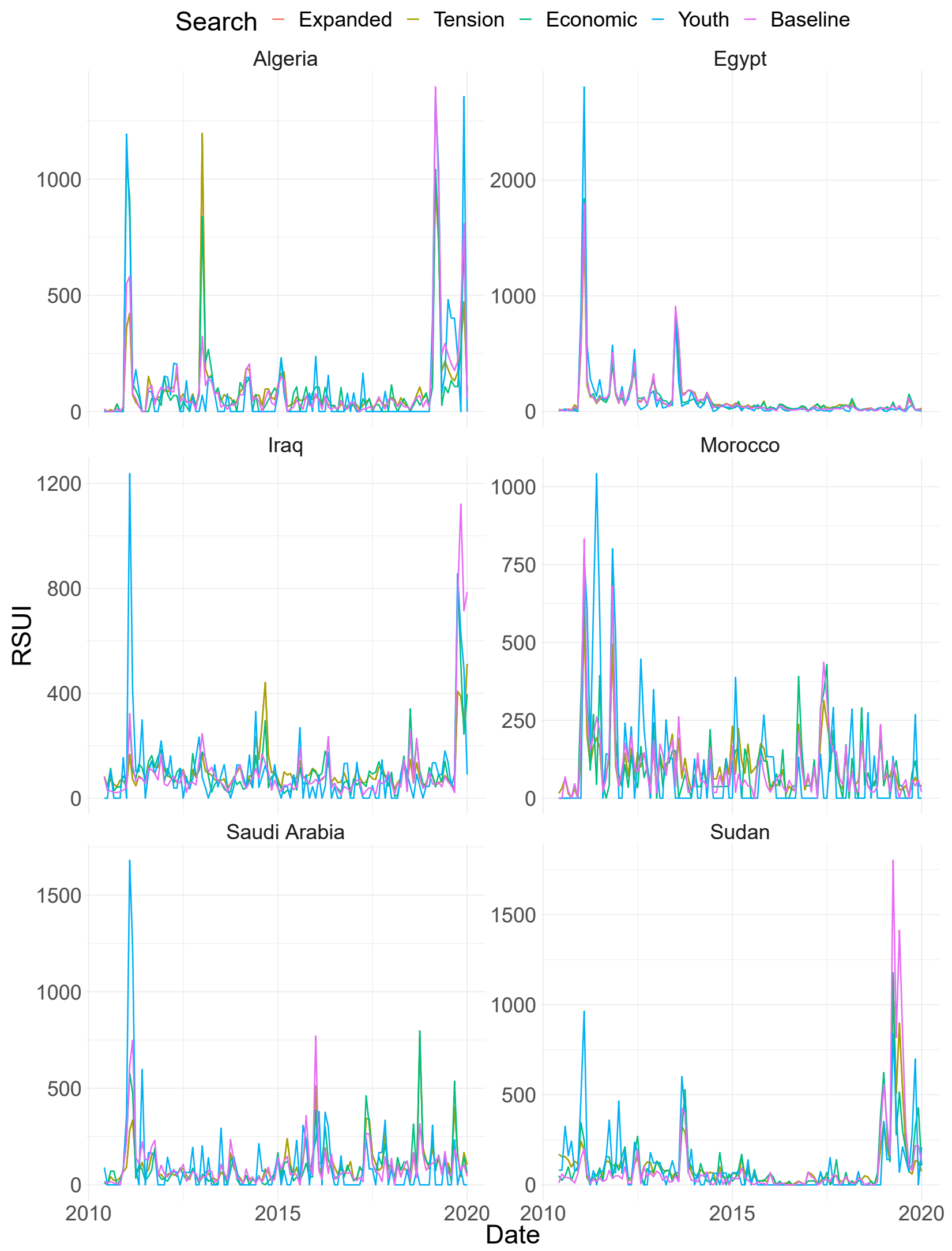

Figure 15: RSUI, June 2010 - present: Largest six Arabic-speaking countries, by search term 


\begin{tabular}{llrrrr}
\hline Statistic & Search modification & $\mathrm{N}$ & Median & $10 \%$ & $25 \%$ \\
\hline Overlap of top 2\% & Expanded & 19 & 0.92 & 0.69 & 0.87 \\
Overlap of top 2\% & Tension & 19 & 0.92 & 0.69 & 0.87 \\
Overlap of top 2\% & Economic & 19 & 0.79 & 0.55 & 0.66 \\
Overlap of top 2\% & Youth & 19 & 0.45 & 0.23 & 0.33 \\
Pearson correl & Expanded & 19 & 0.91 & 0.73 & 0.76 \\
Pearson correl & Tension & 19 & 0.91 & 0.73 & 0.76 \\
Pearson correl & Economic & 19 & 0.84 & 0.57 & 0.71 \\
Pearson correl & Youth & 19 & 0.69 & 0.45 & 0.60 \\
Spearman correl & Expanded & 19 & 0.83 & 0.64 & 0.79 \\
Spearman correl & Tension & 19 & 0.83 & 0.64 & 0.79 \\
Spearman correl & Economic & 19 & 0.70 & 0.52 & 0.59 \\
Spearman correl & Youth & 19 & 0.54 & 0.35 & 0.42 \\
\hline
\end{tabular}

Table 5: Within-country correlations with baseline, varying search terms 


\section{$5 \quad$ Statistical Properties of the Index}

In this section we discuss the statistical properties of the index. These are useful both for understanding how to interpret the index, as well as for understanding the temporal and spatial correlation of major unrest events and their predictability.

\subsection{Cross-sectional distribution}

We start by proposing a functional form for the cross-sectional distribution of the RSUI index. We assume that for values in excess of some cutoff $\bar{m}$, the full sample $R S U I_{i t}^{A}$ can be described by:

$$
\mathbb{P}\left(R S U I_{i t}^{A}<M\right)=F(M) \quad \text { for } M \geq \bar{m}
$$

Where:

$$
F(M)=1-(a(M-\bar{m})+1)^{-b}
$$

We think of $\bar{m}$ as a filter for noise; below this threshold there is no meaningful information in the index. An appealing property of this distribution is that the fraction of observations above $M$ is proportionate to $M-\bar{m}+1 / a$. That is:

$$
\log (1-F(M))=-b \log a-b \log (M-\bar{m}+1 / a)
$$

In other words, if $\bar{m}-1 / a$ is small, then a one percent increase in $M$ above the threshold $\bar{m}$ implies a $b$ percent decrease in the number of observations at least this large. If this describes the data well then this provides a meaningful interpretation of changes in the A index.

We estimate this density by maximum likelihood, and report the point estimates and standard errors in Table 6 with $\bar{m}=200$. Both parameters are sharply identified by the data, with small standard errors. And, as shown in Figure 16, the fitted and empirical distributions match very closely.

\begin{tabular}{cc}
$\mathrm{a}$ & $\mathrm{b}$ \\
\hline 0.003 & 2.050 \\
$(0.00016)$ & $(0.0752)$
\end{tabular}

Table 6: Full-sample maximum-likelihood estimation of cross sectional density, $\mathrm{N}=6926, \bar{m}=200$. Standard errors in parentheses.

Appendix D provides further robustness checks, showing that 1) estimates for the parameters of the cross-sectional distribution are unaffected by the choice of the cutoff $\bar{m}$ and that 2 ) withincountry estimates of the parameters are not significantly different from the aggregate estimates.

These results give a useful interpretation of large observations of the headline index. Imagine one wishes to compare two observations in the upper tail of the distribution, say $M_{1}$ and $M_{2}$ with $M_{1}<M_{2}$ and that both are large relative to $\bar{m}-1 / a \simeq 130$. Then we can compare them using a simple rule of thumb: that if $M_{2}$ is $x \%$ larger than $M_{1}$ then there usually will be approximately 


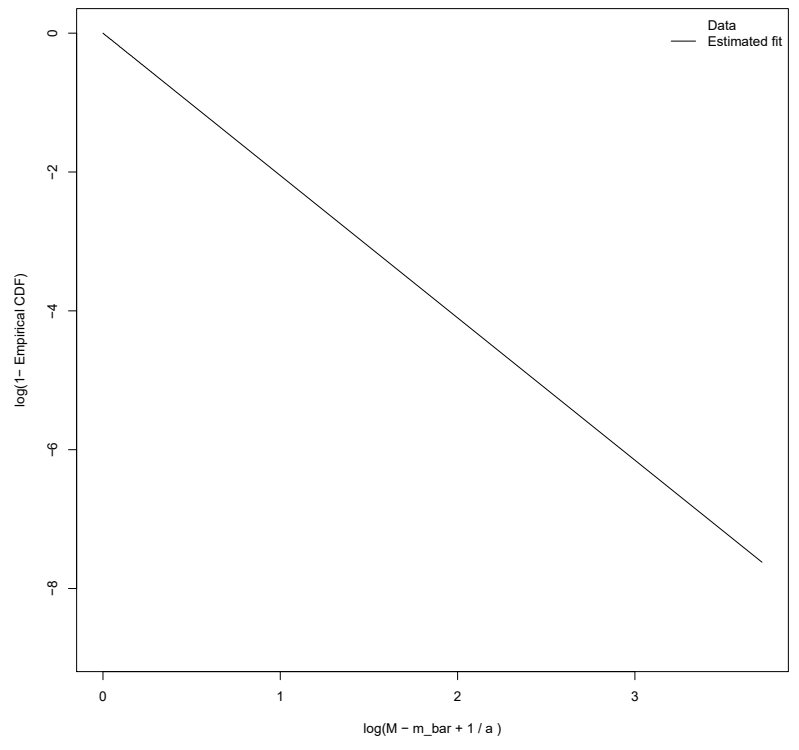

(a) Log transformation

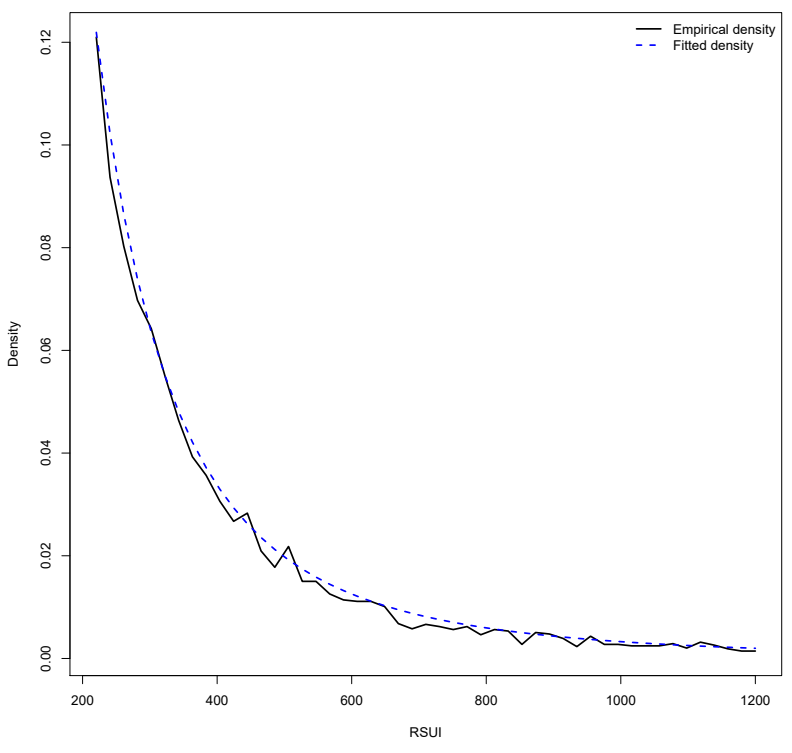

(b) Fitted density

Figure 16: Cross-sectional RSUI density, empirical and estimated, $\bar{m}=200$

$2 x \%$ fewer observations larger than $M_{2}$ than $M_{1}$ (using here that $b \simeq 2$ ). This rule of thumb holds both within individual countries, and across the sample as a whole.

\subsection{Correlation of unrest events in time and space}

At first glance, social unrest appears to be correlated across both space and time, with regional waves of unrest - such as the Arab Uprisings or recent protests in Latin America - appearing to be a relatively common phenomenon. Yet isolated unrest can and does occur. For instance, mass protests in Korea during 2016 leading to the impeachment of President Park Guen-hye and protests in France over public spending and pensions during late 2019 and early 2020 are not part of regional waves of unrest. So, to what extent is social unrest a correlated phenomenon? Our aim in this section is to examine this question, and document the conditional correlations of social unrest both in time in space. Note that our aim here is purely descriptive. Notions of causality such as whether protests beget more protest or simply reflect persistent underlying drivers - are beyond the scope of this paper.

To analyze the dynamic and spatial correlations in social unrest we define:

$$
\begin{aligned}
& s_{i, t}=\text { Months since last unrest event in country } i \\
& u_{i, t}=\text { Months since last unrest event in neighbors of country } i
\end{aligned}
$$

Neighboring countries are defined as those which share borders. Figure 17 shows the distribution of the times since social unrest events. As individual countries often have several neighbors, the 
time since neighboring country events is typically smaller, averaging 32 months versus 60 months for own-country events.

We can then create indicators for these times, dividing them into $K$ distinct intervals $\left(t_{0}, t_{1}\right]$, $\left(t_{1}, t_{2}\right], \ldots,\left(t_{K-1}, t_{K}\right]$ :

$$
S_{i, t}^{k}=s_{i, t} \in\left(t_{k-1}, t_{1}\right] \quad U_{i, t}^{k}=u_{i, t} \in\left(t_{k-1}, t_{1}\right]
$$

Then we estimate the following panel regression:

$$
\text { event }_{i, t}=\alpha_{i}+\eta_{t}+\sum_{k \in \mathcal{K}} \beta_{k}^{d} S_{i, t}^{k}+\sum_{k \in \mathcal{K}} \beta_{k}^{n} U_{i, t}^{k}+e_{i t}
$$

where event $t_{i, t}$ is an indicator for an unrest event and $\alpha_{i}$ and $\eta_{t}$ are country and time fixed effects. Using this framework, we can interpret $\beta^{d}$ and $\beta^{n}$ as the incremental probability of an unrest event conditional on there being either a domestic or neighboring event during the last $\left(t_{k-1}, t_{1}\right]$ months.

Table 7 presents the results of this exercise. The first column simply estimates the conditional average the unrest event indicator over the full sample, a little over one percent of months feature an unrest event. In column (2) we restrict estimation to the sub-sample where there has been at least one prior unrest event, resulting in an increase in the unconditional average event probability to nearly two percent. This specification is relevant null model for specifications (3) through (5) note the same sample size as in (2) - as this specification can only be estimated on observations with at least one prior event.

Specifications (3) through (5) estimate the probability of a social unrest event within a country conditional on one occurring previously. As shown in specification (3), this probability rises sharply but briefly during the months following a social unrest event, rising by nearly 4 percent immediately following an unrest event. ${ }^{15}$ This is both statistically significant and quantitatively large, representing a quadrupling of the rate over that in times far from past unrest events. ${ }^{16}$ This impact decays slowly over the next nearly two years.

Of course, these effects may simply reflect selection, as countries with higher rates of average unrest will constitute a larger fraction of observations, particularly in the periods immediately after an event. We therefore correct for this in specification (4), which includes country fixed effects and, along with specification (8), represents the headline results in this section. These figures thus represent the marginal increase in the conditional probability of unrest over a county's own average rate. Although the immediate increase falls to around 3.5 percent, this still represents a meaningful increase, with an approximate tripling over the sample average. However, accounting for average effects results in a much less persistent response, with no statistically discernible impact at horizons longer than six months. Specification (5) includes time fixed effects, which account for correlated

\footnotetext{
${ }^{15}$ Part 1 of the definition of an event requires that the RSUI attain a local peak, and thus there are no consecutive unrest events. As a result, months immediately following an unrest event are dropped from the sample.

${ }^{16}$ The constant term 0.012 is less than one quarter of $0.012+0.037 \simeq 0.049$, the recurrence rate of $2-3$ months after an unrest event.
} 


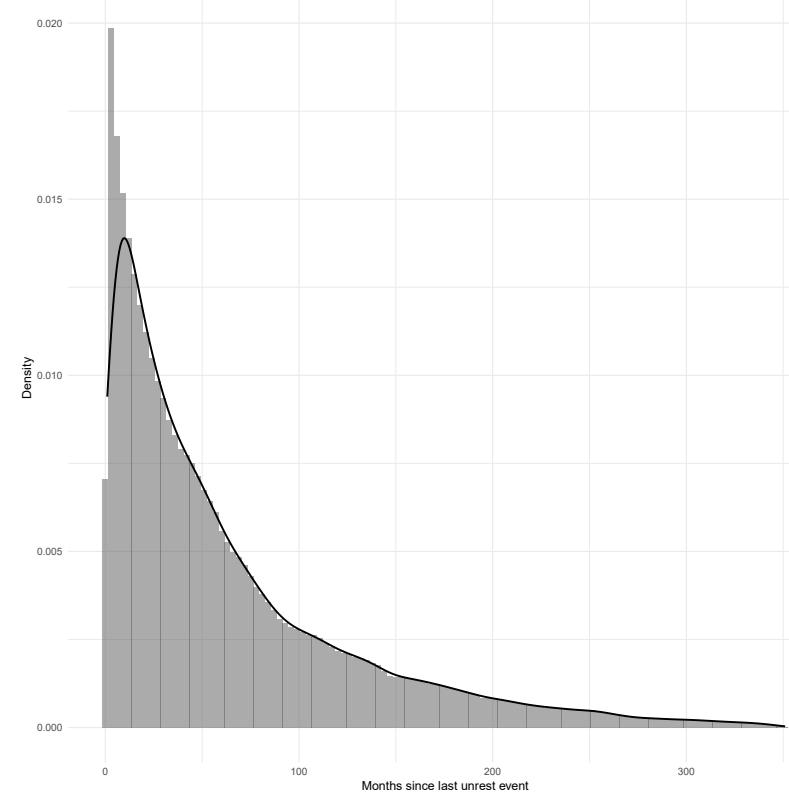

(a) Own country events, $s_{i, t}$



(b) Neighboring country events, $u_{i, t}$

Figure 17: Distribution of time since last event

average global variation in event probabilities, and which looks little different from specification (4).

Specification (6) performs a similar exercise but using time after neighboring-country events only. In this case, time fixed effects make little sense, as they will absorb any variation in neighboring countries which is correlated with global trends. The effect of neighboring-country events on the probability of social unrest is smaller, at a little over half the own-country effect, but still statistically significant. However, this effect seems to be slightly longer-lasting than the effect of purely domestic events. Specification (7) is identical to (6) except restricted to the sub-sample used for specification (8).

Along with specification (4), specification (8) is the other headline estimate. It reports estimates for the full specification in equation (1). This broadly confirms the findings of the separate regressions: within-country unrest is associated with an approximate 3 percentage point increase (an approximate quadrupling) in the rate of social unrest in the short term, but the effect is insignificant after six months; unrest events in neighboring countries are associated with roughly a doubling of the rate of unrest.

The fit of the regressions is in general fairly poor, with a naive $\mathrm{R}^{2}$ is no better than five percent. ${ }^{17}$ In causal settings this might be a sign of mis-specification and thus a concern. But in a purely descriptive context this is not relevant. Instead, it simply means that there is considerable variation in the realized outcomes beyond the averages conditional on time since last event. ${ }^{18}$

\footnotetext{
${ }^{17}$ As is customary in panel regressions, the $R^{2}$ and adjusted $R^{2}$ are computed using data after fixed effects are taken out. The naive $\mathrm{R}^{2}$ does not account for this.

${ }^{18}$ We return to this theme when discussing predictability in the next section
} 
Table 7: Conditional probabilities of social unrest.

\begin{tabular}{|c|c|c|c|c|c|c|c|c|}
\hline & \multicolumn{8}{|c|}{ Dependent variable: Social unrest event } \\
\hline & $(1)$ & $(2)$ & $(3)$ & $(4)$ & $(5)$ & $(6)$ & $(7)$ & $(8)$ \\
\hline Event, last 2-3 months & & & $\begin{array}{c}0.037^{* * *} \\
(0.007)\end{array}$ & $\begin{array}{c}0.027^{* * *} \\
(0.007)\end{array}$ & $\begin{array}{c}0.025^{* * *} \\
(0.007)\end{array}$ & & & $\begin{array}{c}0.028^{* * *} \\
(0.008)\end{array}$ \\
\hline Event, last 4-6 months & & & $\begin{array}{c}0.029^{* * *} \\
(0.006)\end{array}$ & $\begin{array}{c}0.020^{* * *} \\
(0.006)\end{array}$ & $\begin{array}{c}0.018^{* * *} \\
(0.006)\end{array}$ & & & $\begin{array}{c}0.021^{* * *} \\
(0.007)\end{array}$ \\
\hline Event, last 7-9 months & & & $\begin{array}{c}0.012^{* *} \\
(0.005)\end{array}$ & $\begin{array}{c}0.004 \\
(0.006)\end{array}$ & $\begin{array}{c}0.002 \\
(0.006)\end{array}$ & & & $\begin{array}{c}0.002 \\
(0.006)\end{array}$ \\
\hline Event, last 10-12 months & & & $\begin{array}{c}0.011^{* *} \\
(0.005)\end{array}$ & $\begin{array}{c}0.003 \\
(0.005)\end{array}$ & $\begin{array}{c}0.002 \\
(0.006)\end{array}$ & & & $\begin{array}{c}0.003 \\
(0.006)\end{array}$ \\
\hline Event, last $13-24$ months & & & $\begin{array}{l}0.004^{*} \\
(0.002)\end{array}$ & $\begin{array}{l}-0.003 \\
(0.002)\end{array}$ & $\begin{array}{l}-0.004 \\
(0.003)\end{array}$ & & & $\begin{array}{l}-0.003 \\
(0.003)\end{array}$ \\
\hline Event, last $25-48$ months & & & $\begin{array}{c}0.001 \\
(0.002)\end{array}$ & $\begin{array}{c}-0.004^{* *} \\
(0.002)\end{array}$ & $\begin{array}{c}-0.004 \\
(0.002)\end{array}$ & & & $\begin{array}{c}-0.005^{* *} \\
(0.003)\end{array}$ \\
\hline Event, last 49-60 months & & & $\begin{array}{c}0.004 \\
(0.003)\end{array}$ & $\begin{array}{c}0.001 \\
(0.003)\end{array}$ & $\begin{array}{c}0.001 \\
(0.003)\end{array}$ & & & $\begin{array}{c}0.001 \\
(0.004)\end{array}$ \\
\hline Neighbor event, last $2-3$ months & & & & & & $\begin{array}{c}0.018^{* * *} \\
(0.003)\end{array}$ & $\begin{array}{c}0.017^{* * *} \\
(0.005)\end{array}$ & $\begin{array}{c}0.016^{* * *} \\
(0.004)\end{array}$ \\
\hline Neighbor event, last 4-6 months & & & & & & $\begin{array}{c}0.009^{* * *} \\
(0.003)\end{array}$ & $\begin{array}{c}0.006 \\
(0.004)\end{array}$ & $\begin{array}{c}0.005 \\
(0.004)\end{array}$ \\
\hline Neighbor event, last 7-9 months & & & & & & $\begin{array}{c}0.008^{* * *} \\
(0.003)\end{array}$ & $\begin{array}{c}0.005 \\
(0.004)\end{array}$ & $\begin{array}{c}0.005 \\
(0.004)\end{array}$ \\
\hline Neighbor event, last $10-12$ months & & & & & & $\begin{array}{c}0.008^{* *} \\
(0.003)\end{array}$ & $\begin{array}{c}0.006 \\
(0.005)\end{array}$ & $\begin{array}{c}0.006 \\
(0.005)\end{array}$ \\
\hline Neighbor event, last 13-24 months & & & & & & $\begin{array}{c}0.008^{* * *} \\
(0.002)\end{array}$ & $\begin{array}{l}0.007^{*} \\
(0.004)\end{array}$ & $\begin{array}{c}0.007^{* *} \\
(0.003)\end{array}$ \\
\hline Neighbor event, last $25-48$ months & & & & & & $\begin{array}{c}0.002 \\
(0.002)\end{array}$ & $\begin{array}{l}-0.001 \\
(0.003)\end{array}$ & $\begin{array}{c}-0.0003 \\
(0.003)\end{array}$ \\
\hline Neighbor event, last $49-60$ months & & & & & & $\begin{array}{c}0.002 \\
(0.003)\end{array}$ & $\begin{array}{c}0.002 \\
(0.005)\end{array}$ & $\begin{array}{c}0.003 \\
(0.005)\end{array}$ \\
\hline Constant & $\begin{array}{c}0.011^{* * *} \\
(0.001)\end{array}$ & $\begin{array}{c}0.017^{* * *} \\
(0.001)\end{array}$ & $\begin{array}{c}0.012^{* * *} \\
(0.001)\end{array}$ & & & & & \\
\hline Fixed effects & None & None & None & Country & Twoways & Country & Country & Country \\
\hline Normalized AIC & -1.706 & -1.247 & -1.252 & -1.258 & -1.277 & -1.489 & -1.175 & -1.177 \\
\hline Naive R2 & 0.011 & 0.017 & 0.022 & 0.028 & 0.046 & 0.02 & 0.028 & 0.032 \\
\hline Observations & 52,736 & 26,126 & 26,126 & 26,126 & 26,126 & 30,828 & 18,768 & 18,768 \\
\hline $\mathrm{R}^{2}$ & & & 0.005 & 0.003 & 0.003 & 0.002 & 0.001 & 0.005 \\
\hline Adjusted $\mathrm{R}^{2}$ & & & 0.005 & -0.001 & -0.018 & -0.002 & -0.005 & -0.002 \\
\hline
\end{tabular}


Moreover, the Akaike information criterion also suggests that the richer models are valid. For example, specifications (2) through (5) show a decline in the AIC and hence an improvement in the fit beyond that expected purely through the inclusion of extra parameters. ${ }^{19}$ Likewise, for specification (8) relative to (7).

Overall, the results of the panel regression exercise suggest that there is considerable spatial and temporal correlation of social unrest. Although social unrest is rare, occurring usually in around 1.3 percent of countries per month, this rate typically triples following an event in the same country, and doubles following one in a neighboring country. Nevertheless, these effects are short-lived, decaying to half a percent or less within 9 months.

\subsection{Predictability}

In the previous section we discussed whether social unrest was more likely after a social unrest event in the same or a neighboring country. Here, we turn to a related but complementary question: can we reliably predict outbreaks of social unrest before they occur? Of course, many factors may potentially predict social unrest including economic, financial, or other social variables. We leave investigation of these questions for other authors and instead ask a more limited question: can the RSUI itself predict social unrest?

Figure 18 illustrated the main point of this section and highlights its comparison with the previous one. The left-hand panel shows the conditional average of the RSUI index around an event. Unsurprisingly, the average RSUI spikes dramatically in the month of the event and declines slowly thereafter. This is essentially the same phenomenon described in the preceding section, just presented a little differently. Yet the RSUI displays a moderate increase (around 174 index points) in the period prior to the event. This raises a natural question: can such an increase be used to reliably predict social unrest?

The right-hand panel suggests not. It shows the mean RSUI conditioned observing increases of at least this magnitude (i.e. 174 index points). This has essentially no predictive power for social unrest events; the RSUI declines sharply back towards its long-run average in the subsequent months. In other words, while almost all social unrest events are preceded by moderate increases in the RSUI, moderate increases in the RSUI are usually followed by a swift regression to the mean.

We investigate this issue more formally by estimating lasso regressions for the index and events. A lasso (least absolute shrinkage and selection operator) regression is a simple machine learning algorithm which selects a model to minimize the out-of-sample forecast error. In this case, we use cross-validation for the out-of-sample exercise and estimate separately for each country:

$$
v_{i, t+h}=\sum_{j=1}^{M} \beta_{i}^{j} v_{i, t-j}
$$

Where $M=18, h=1, \ldots, 24$ and $v_{i t}$ is either the RSUI or event indicator for country $i$ in period $t$.

\footnotetext{
${ }^{19}$ The normalized AIC is divided by the sample size. We can only compare model fit when estimated on the same data, i.e. specifications (2) through (5) with each other, and specifications (7) and (8).
} 


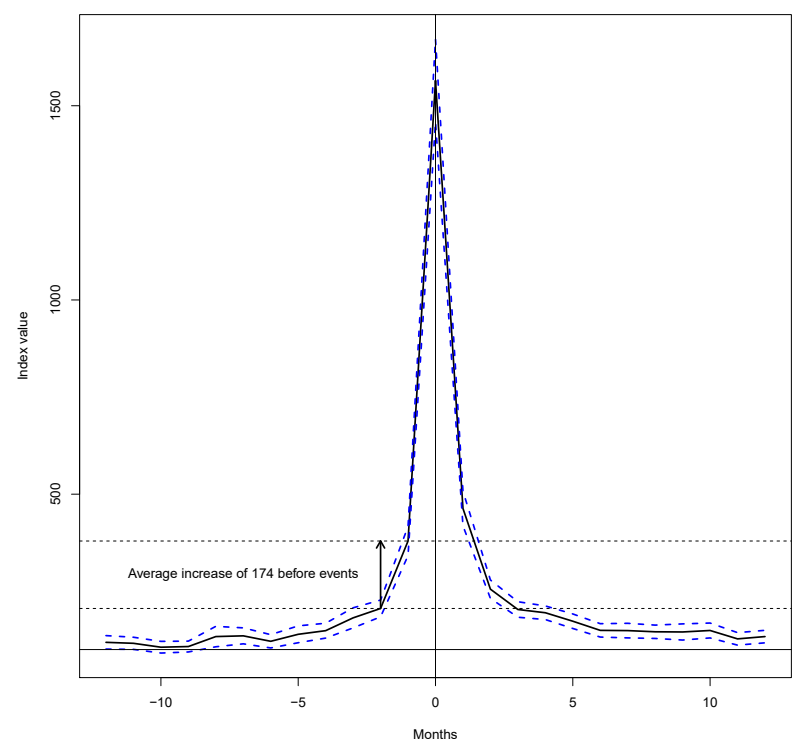

(a) Events

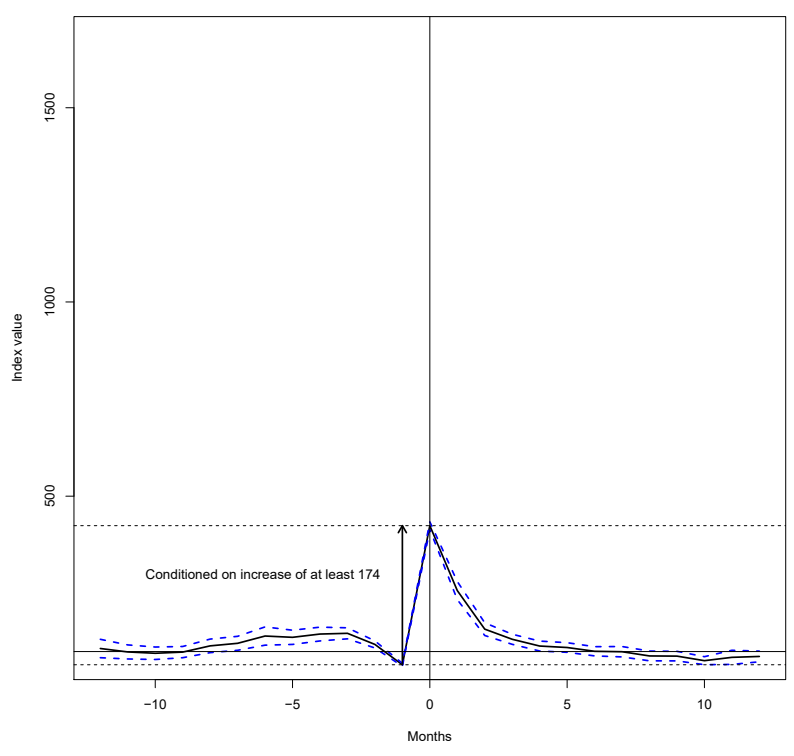

(b) Large increases

Figure 18: Mean RSUI around events and large increases

This approach therefore calculates the best country- and horizon-specific predictive model for the RSUI using up to a year-and-a-half of prior outcomes data. The purpose of using a cross-validated lasso is to try to estimate the most reliably informative predictive model.

For each country-horizon predictive model we compute three measures of predictability: the well-known Granger-Newbold measure, which is the fraction of variance of the outcome explained by the forecast, analogous to the $\mathrm{R}^{2}$; the Theil uncertainty statistic, which is less than one when the forecast is better than the long-run average; and the Diebold and Kilian (2001) statistic which measures predictability relative to the long-run error variance.

Table 8 compiles these measures by selecting the most predictive horizon for each country and then taking the cross-country average. Despite choosing the most successful predictions for each country, the predictability of each series is low. Indeed, the lasso regression typically selects at most only one lag of the RSUI when predicting future values of the index, and typically at very short lags. Likewise, the Granger-Newbold statistic shows that the best forecast explains barely three percent of the variation in outcomes. ${ }^{20}$ The Theil measure implies that the best forecast is little better than guessing the long-run average (which would produce a score of 1). Figure 19 presents the average and country-specific results by horizon for two measures. For RSUI events, predictability is even lower, with almost all country-horizon pairs selecting zero lags, i.e. the best predictive model in almost all cases actually is identically the country average.

How should we interpret this lack of predictability, particularly in the light of the regression results of the previous section? To start with, note that these are not inconsistent. Just because

\footnotetext{
${ }^{20}$ Not coincidentally very close to the $\mathrm{R}^{2}$ of the regressions in the preceding section.
} 


\begin{tabular}{lrr}
\hline \hline & Index & Events \\
\hline Number of non-zero coefficients & 1.03 & 0.02 \\
Horizon of most non-zero coefficients & 1.50 & 1.03 \\
Granger-Newbold predictability & 0.03 & 0.00 \\
Theil U-statistic & 0.92 & 1.00 \\
Diebold-Kilian predictability & 0.11 & 0.05 \\
\hline
\end{tabular}

Table 8: Measures of predictability of index and events. Maximum within countries, then averaged across countries

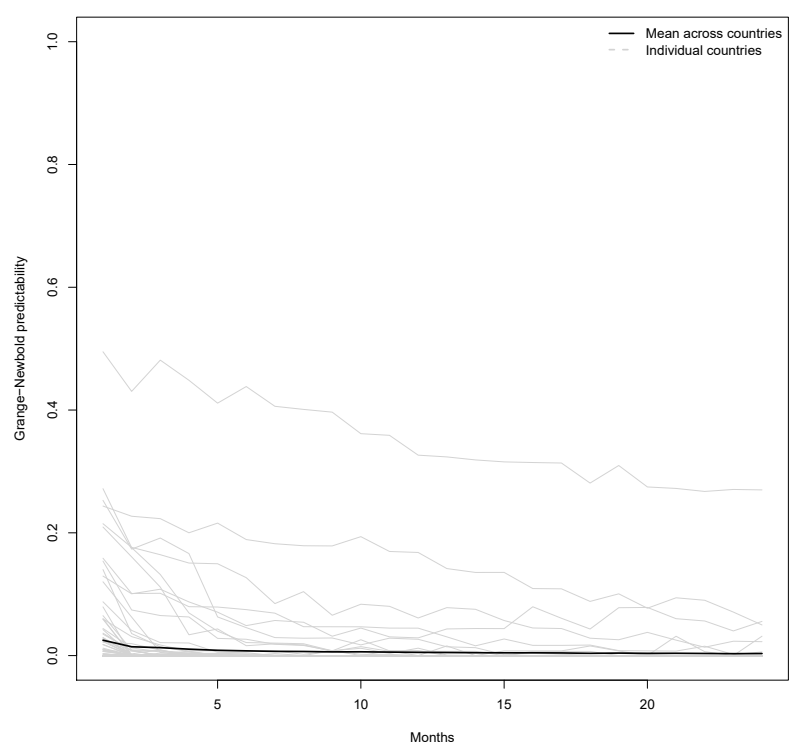

(a) Grange-Newbold predictability

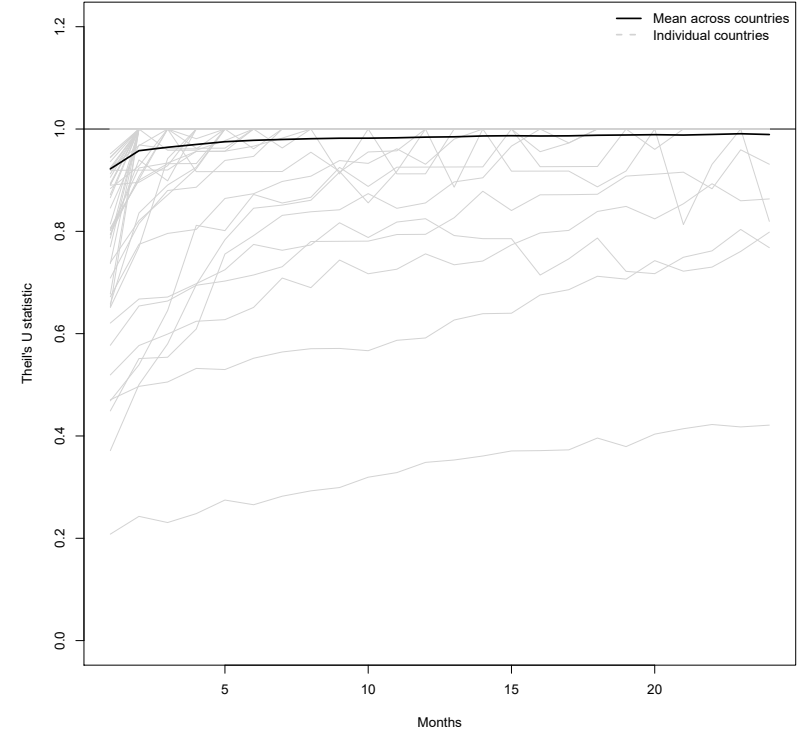

(b) Theil's U statistic

Figure 19: Measures of predictability of the RSUI series

two variables are correlated does not mean that either is a good predictor of the other. Social unrest indicates a higher probability of future unrest, but social unrest is sufficiently rare and driven by so many other factors that using past social unrest to predict future unrest results in such a small improvement in forecasting power as to be statistically useless. To make the point differently, the probability of winning a lottery rises conditional on buying a ticket. But if lottery wins are sufficiently rare, holding a lottery will not be a reliable predictor of winning.

A more constructive interpretation of these results is that social unrest likely happens for incredibly varied reasons, and can be triggered by seemingly minor events (e.g. increased subway fares). The rareness of events, combined with this apparent susceptibility to triggers, make individual social unrest events simply very hard to predict. As a result, average effects (however sharply identified) explain little of the variation in outcomes. Thus we can make statements both about average impacts (as in the preceding section) but still struggle to predict individual events. 


\section{Conclusions and possible applications}

This paper does three things. First, it introduces a novel method for measuring and monitoring social unrest using article counts from international press, and presented a way of coding sharp spikes in the index into events. Second, we have shown that the events and the index correlate well with independent narrative courses during three diverse case studies. We also showed that the index is robust to choice of language, sources, and search terms. From this evidence, we conclude that the index and events likely measure realized social unrest rather than simply variation in media interest over time. Third, we provide some basic statistical analysis essential for interpreting the index, concluding that: the log of the index is proportional to its percentile rank in both withinand cross-country distributions; that social unrest is temporally and spatially correlated - social unrest raises the average probability of further unrest over the next six months by about three percentage points in the same country and about one percentage points in neighbors; but that that social unrest is not itself a reliable predictor of future social unrest.

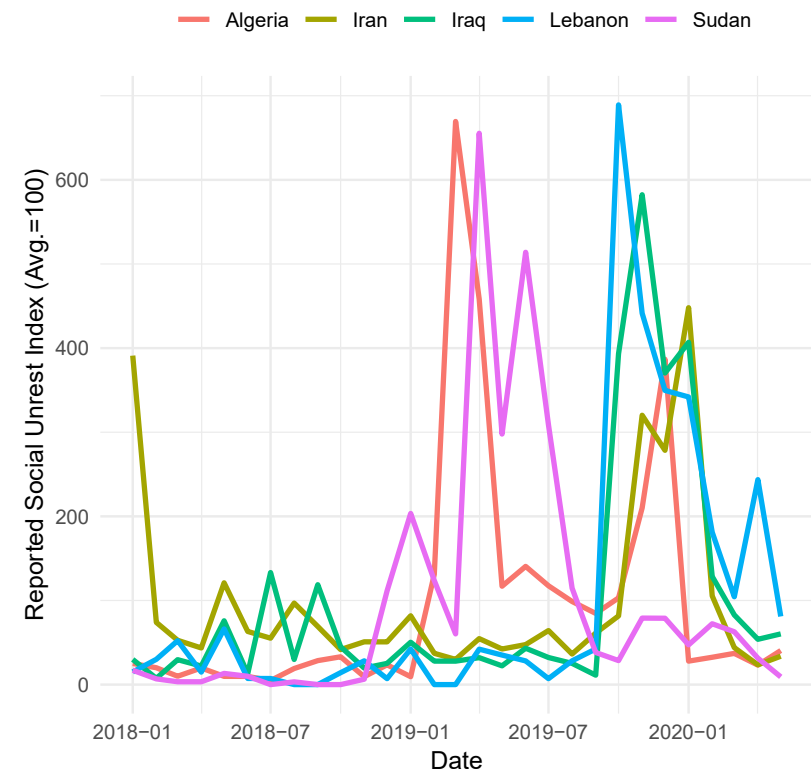

(a) Select Middle Eastern countries

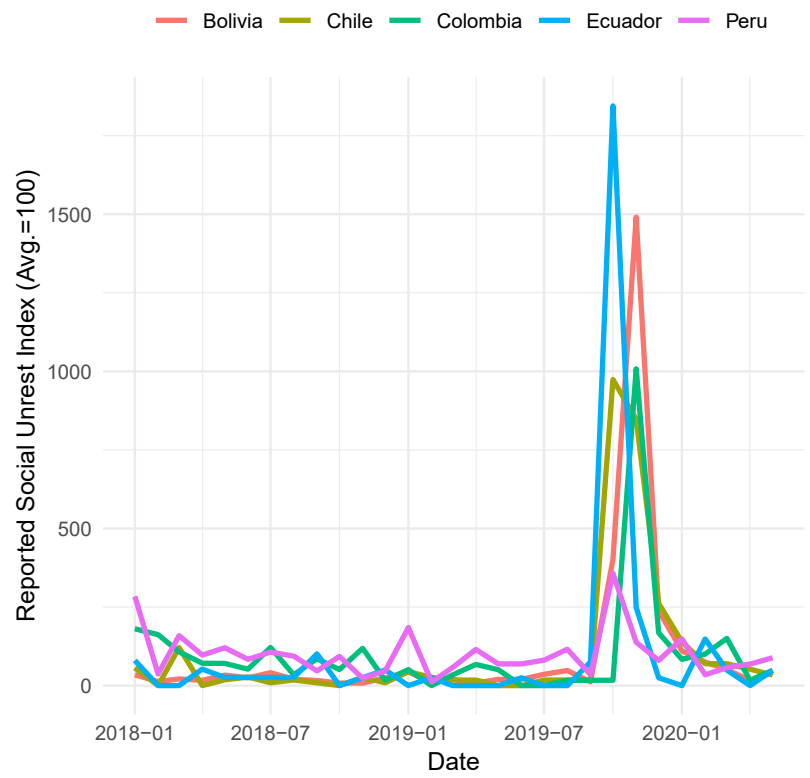

(b) Select South American countries

Figure 20: RSUI January 2018 - present

These results have two main applications: providing reliable monitoring of social unrest; and in research on the causes and consequences of social unrest. To illustrate this first point, Figure 20 presents the latest RSUI data for select Middle Eastern and South American countries, indexed to 100 within the time periods presented. In both cases, the RSUI provides a timely, high-frequency data source for summarizing the timing and relative importance of episodes of social unrest. In particular, the timing and frequency of unrest across the two regions is very clearly differentiated. The timing of social unrest events is weakly correlated across the Middle Eastern countries, with sporadic outbursts throughout 2019, and some countries showing multiple unrest events (Algeria, 
Iran). This contrasts with recent protests in South America, which shows up as a single regional outburst from October 2019 onwards.

As for future research, the RSUI and the event listing - which are both freely available online - provide a rich battery of documented examples against which theories about the economic (and non-economic) causes and consequences of social unrest can be tested. The global coverage and monthly frequency of the RSUI data provide the granularity to investigate important issues such as the impact of unrest on financial markets and investment, the disruption to trade due to unrest, and the effect of corruption, governance, or poverty on unrest. A key challenge in all these areas is the issue of endogeneity: if social unrest and economic performance might each affect the other, or are jointly determined by a third factor. The analysis presented here suggests some ways of solving this problem. In particular, the results presented here on predictability and spillovers suggest that the exact timing of social unrest is a near-random event and that regional waves of unrest might be a useful instrument for domestic unrest. ${ }^{21}$ We leave these questions to future work.

\footnotetext{
${ }^{21}$ See Acemoglu et al. (2019) for an example of this strategy when studying democratization, instrumented by regional waves.
} 


\section{References}

Acemoglu, D., S. Naidu, P. Restrepo, and J. A. Robinson (2019). Democracy does cause growth. Journal of Political Economy 127(1), 47-100.

Ahir, H., N. Bloom, and D. Furceri (2018). The world uncertainty index. Mimeo.

Ali, M., O.-H. Fjeldstad, B. Jiang, and A. B. Shifa (2019). Colonial legacy, state-building and the salience of ethnicity in sub-saharan africa. The Economic Journal 129(619), 1048-1081.

Baker, C. (2016). The 2014 thai coup and some roots of authoritarianism. Journal of Contemporary Asia 46(3), 388-404.

Baker, S. R., N. Bloom, and S. J. Davis (2016). Measuring economic policy uncertainty. The Quarterly Journal of Economics 131(4), 1593-1636.

Banks, A. and K. A. Wilson (2020). Cross-national time-series data archive.

Barro, R. J. (1991). Economic growth in a cross section of countries. The quarterly journal of economics 106(2), 407-443.

Bodnaruk Jazayeri, K. (2016). Identity-based political inequality and protest: The dynamic relationship between political power and protest in the middle east and north africa. Conflict Management and Peace Science 33(4), 400-422.

Briceño-Ruiz, J. (2019). The crisis in venezuela: A new chapter, or the final chapter? Latin American Policy 10(1), 180-189.

Caldara, D. and M. Iacoviello (2018). Measuring geopolitical risk. FRB International Finance Discussion Paper (1222).

Choe, H. and J. Kim (2012). South korea's democratization movements, 1980-1987: political structure, political opportunity, and framing. Inter-Asia Cultural Studies 13(1), 55-68.

Ciocan, D. and B. Wüest (2016). Censorship of the arab spring in mena media.

Dalpino, C. (2011). Thailand in 2010: Rupture and attempts at reconciliation. Asian Survey 51(1), $155-162$.

Diebold, F. X. and L. Kilian (2001). Measuring predictability: theory and macroeconomic applications. Journal of Applied Econometrics 16(6), 657-669.

Fraiberger, S. P., D. Lee, D. Puy, and R. Rancier (2018). Media sentiment and international asset prices. The World Bank.

Gutiérrez, A. (2017). Venezuela's economic and social development in the era of chavism. Latin American Policy 8(2), 160-188. 
Harari, M. and E. L. Ferrara (2018). Conflict, climate, and cells: a disaggregated analysis. Review of Economics and Statistics 100(4), 594-608.

Hellmeier, S., E. G. Rød, and N. B. Weidmann (2019). Coding instructions for the mass mobilization in autocracies database, version 2.0 .

Hlatshwayo, S., A. Oeking, M. M. Ghazanchyan, D. Corvino, A. Shukla, and M. L. Y. Leigh (2018). The Measurement and Macro-Relevance of Corruption: A Big Data Approach. International Monetary Fund.

Jirasavetakul, L.-B. F. and M. A. Spilimbergo (2018). Economic Policy Uncertainty in Turkey. International Monetary Fund.

Keyes, C. (2006). The destruction of a shrine to brahma in bangkok and the fall of thaksin shinawatra: the occult and the thai coup in thailand of september 2006.

Kim, N. (2017). Candlelight and the yellow ribbon: Catalyzing re-democratization in south korea. Asia-Pacific Journal: Japan Focus 15, 1-17.

Klopp, J. M. and E. Zuern (2007). The politics of violence in democratization: lessons from kenya and south africa. Comparative Politics, 127-146.

Manela, A. and A. Moreira (2017). News implied volatility and disaster concerns. Journal of Financial Economics 123(1), 137-162.

Ponticelli, J. and H.-J. Voth (2020). Austerity and anarchy: Budget cuts and social unrest in europe, 1919-2008. Journal of Comparative Economics 48(1), 1-19.

Prasirtsuk, K. (2009). Thailand in 2008: Crises continued. Asian Survey 49(1), 174-184.

Prasirtsuk, K. (2010). Thailand in 2009: Colored by turbulence. Asian Survey 50(1), 203-210.

Prasirtsuk, K. (2015). Thailand in 2014: another coup, a different coup? Asian Survey 55(1), 200-206.

Schock, K. (1999). People power and political opportunities: Social movement mobilization and outcomes in the philippines and burma. Social problems 46(3), 355-375.

Tucker, J. A. (2007). Enough! electoral fraud, collective action problems, and post-communist colored revolutions. Perspectives on politics 5(3), 535-551.

Waldmeir, P. (1997). Anatomy of a miracle: The end of apartheid and the birth of the new South Africa. WW Norton \& Company.

Worth, R. F. (2016). A Rage for Order: The Middle East in Turmoil, from Tahrir Square to ISIS. Macmillan. 


\section{A Further details on construction}

Here, we include further details on the construction of the alternative indices and events. Table 9 reports the search terms used for the alternate languages, and Table 10 the listing of modified searches and their justifications.

\begin{tabular}{|c|c|}
\hline Language & Search Algorithm \\
\hline English & $\begin{array}{l}\text { (Tunisia) and (protest* or revolution or ((civil or domestic) near } 10 \\
\text { unrest) ) and wc }>99 \text { not (anniversary or war or memorial or movie } \\
\text { or art) }\end{array}$ \\
\hline French equivalent & $\begin{array}{l}\text { (Tunisie) and (protest* or revolution* or manifestation* ((civil or } \\
\text { domestique) near10 troubles)) and wc }>99 \text { not (anniversaire or } \\
\text { guerre or commémoratif or film or art) }\end{array}$ \\
\hline Arabic equivalent & 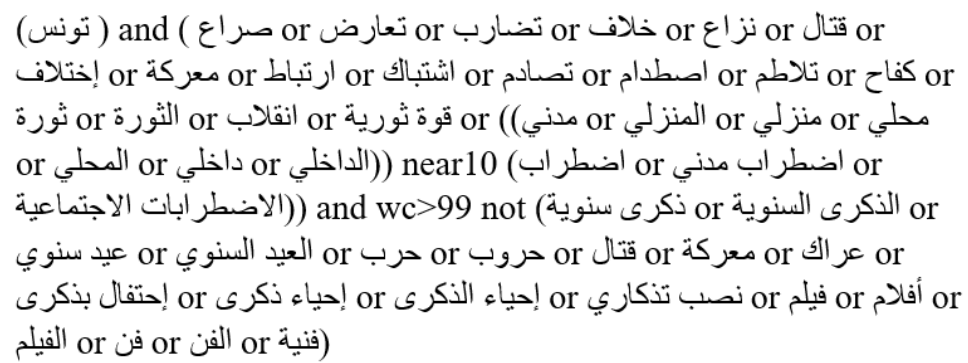 \\
\hline
\end{tabular}

Table 9: Alternate language search terms

\begin{tabular}{|c|c|c|c|}
\hline Country & Change & Reason & Category \\
\hline Azerbaijan & not "referendum" & $\begin{array}{l}\text { Reference to opposition member } \\
\text { leaving their parties in protest of ref- } \\
\text { erendum bias }\end{array}$ & Past events \\
\hline Chad & $\begin{array}{l}\text { not "brother leader of } \\
\text { the revolution" }\end{array}$ & $\begin{array}{l}\text { Libyan-Chadian joint cooperation } \\
\text { committee in Tripoli }\end{array}$ & Country-Specific \\
\hline Chad & $\begin{array}{l}\text { not "brother leader of } \\
\text { the revolution" }\end{array}$ & $\begin{array}{l}\text { Al-Qhadhafi meets Afghan delega- } \\
\text { tion in Chad }\end{array}$ & Country-Specific \\
\hline Chad & $\begin{array}{l}\text { not "brother leader of } \\
\text { the revolution" }\end{array}$ & $\begin{array}{l}\text { Chad president meets with Al- } \\
\text { Qhadhafi in Tripoli over bilateral re- } \\
\text { lations }\end{array}$ & Country-Specific \\
\hline Chad & $\begin{array}{l}\text { not "brother leader of } \\
\text { the revolution" }\end{array}$ & $\begin{array}{l}\text { Tripartite summit between Libya, } \\
\text { Chad, and CAR in Ndjamena }\end{array}$ & Country-Specific \\
\hline Chad & $\begin{array}{l}\text { not "brother leader of } \\
\text { the revolution" }\end{array}$ & CAR-Chad border crisis & Country-Specific \\
\hline Colombia & not "maduro" & 02/19 picks up Venezuela crisis & Wrong country \\
\hline
\end{tabular}




\begin{tabular}{|c|c|c|c|}
\hline Croatia & not "boat" & $\begin{array}{l}06 / 14 \text { picks up diplomatic protest } \\
\text { over a patrol boat in Slovenian wa- } \\
\text { ters }\end{array}$ & Diplomatic \\
\hline Croatia & not "Brazil" & $\begin{array}{l}\text { 06/14 picks up protests coincide } \\
\text { with Brazil-Croatia World Cup } \\
\text { match }\end{array}$ & Incorrect usage \\
\hline Croatia & not "World Cup" & $\begin{array}{l}\text { Punk group Pussy Riot protest at } \\
\text { World Cup final }\end{array}$ & Incorrect usage \\
\hline Cyprus & not "rape" & $\begin{array}{l}\text { 01/20 Protesters in London call for } \\
\text { Cyprus boycott over rape case }\end{array}$ & Wrong country \\
\hline Czech Republic & not "velvet revolution" & $\begin{array}{l}\text { Throughout: Picks up references to } \\
\text { the velvet revolution }\end{array}$ & Past events \\
\hline Czech Republic & not "velvet revolution" & References to "Velvet Revolution" & Country-Specific \\
\hline Denmark & not "cartoon" & $\begin{array}{l}\text { Jyllands-Posten cartoon contro- } \\
\text { versy }\end{array}$ & Wrong country \\
\hline Ecuador & not "Assange" & $\begin{array}{l}\text { Protests in UK over Julian As- } \\
\text { sange's extradition to Ecuador }\end{array}$ & Diplomatic \\
\hline Estonia & $\begin{array}{l}\text { not ("Baltic Way" or } \\
\text { "Baltic Chain") }\end{array}$ & $\begin{array}{l}\text { Throughout: references to historical } \\
\text { events }\end{array}$ & Past events \\
\hline Estonia & not "digital revolution" & $\begin{array}{l}7 / 17 \text { event picks up wrong sort of } \\
\text { revolution }\end{array}$ & Incorrect usage \\
\hline Ghana & $\begin{array}{l}\text { not "brother leader of } \\
\text { revolution" }\end{array}$ & $\begin{array}{l}\text { References to the "brother leader of } \\
\text { revolution" Al-Qadhafi }\end{array}$ & Country-Specific \\
\hline Guatemala & $\begin{array}{l}\text { not "Claudia Patricia } \\
\text { Gomez Gonzalez" or } \\
\text { "Nicaragua" or "U.S." } \\
\text { or "Anders Kompass" }\end{array}$ & $\begin{array}{l}\text { Protests in Washington over } \\
\text { Guatemalan woman killed trying to } \\
\text { cross border }\end{array}$ & Diplomatic \\
\hline Haiti & not "hithole" & $\begin{array}{l}01 / 18 \text { picks up diplomatic protest } \\
\text { over Trump statement }\end{array}$ & Wrong country \\
\hline India & not "Litte India" & $\begin{array}{l}\text { 12/13 picks up disturbances in Little } \\
\text { India in Singapore }\end{array}$ & Wrong country \\
\hline Iran & $\begin{array}{l}\text { not "Islamic Revolu- } \\
\text { tion" }\end{array}$ & $\begin{array}{l}\text { Throughout: Picks up political and } \\
\text { government organizations }\end{array}$ & Country-Specific \\
\hline Iraq & not "Scott" & $\begin{array}{l}02 / 96 \text { picks up controversy over } \\
\text { arms-to-Iraq scandal in the "Scott" } \\
\text { report }\end{array}$ & Wrong country \\
\hline Japan & not ("anti-Japan*") & $\begin{array}{l}9 / 12 \text { picks up demonstrations in } \\
\text { China }\end{array}$ & Wrong country \\
\hline
\end{tabular}




\begin{tabular}{|c|c|c|c|}
\hline Japan & $\begin{array}{l}\text { not ("Taiwan" and } \\
\text { "Lee" and "China") }\end{array}$ & $\begin{array}{l}\text { 4/01 picks up Chinese diplomatic } \\
\text { protests over visa for former Tai- } \\
\text { wanese president }\end{array}$ & Diplomatic \\
\hline Kuwait & not "Syria" & $\begin{array}{l}\text { International protest against Syrian } \\
\text { crackdown on pro-democracy move- } \\
\text { ment }\end{array}$ & Wrong country \\
\hline Kyrgyz Republic & not "amnesty" & $\begin{array}{l}\text { Parliament passes general amnesty } \\
\text { for protesters }\end{array}$ & Past events \\
\hline Latvia & $\begin{array}{l}\text { not ("Baltic Way" or } \\
\text { "Baltic Chain") }\end{array}$ & $\begin{array}{l}\text { Throughout: references to historical } \\
\text { events }\end{array}$ & Past events \\
\hline Lebanon & $\begin{array}{l}\text { not "Islamic Revolu- } \\
\text { tion" }\end{array}$ & $\begin{array}{l}\text { Throughout: Picks up political } \\
\text { party }\end{array}$ & Country-Specific \\
\hline Lebanon & not "London" & $\begin{array}{l}\text { International protests after Israeli } \\
\text { troops crossed over to Lebanon to } \\
\text { fight Hezbollah fighters }\end{array}$ & Wrong country \\
\hline Lithuania & $\begin{array}{l}\text { not ("Baltic Way" or } \\
\text { "Baltic Chain") }\end{array}$ & $\begin{array}{l}\text { Throughout: references to historical } \\
\text { events }\end{array}$ & Past events \\
\hline Lithuania & not "EU summit" & $\begin{array}{l}\text { EU summit in Lithuania; protesters } \\
\text { in Kiev demanding impeachment of } \\
\text { president }\end{array}$ & Wrong country \\
\hline Malaysia & $\begin{array}{l}\text { not ("13 May" or "May } \\
13 ")\end{array}$ & Major incident of historical unrest & Past events \\
\hline Mali & $\begin{array}{l}\text { not "Cairo" } \\
\text { "Bahrain" }\end{array}$ & $\begin{array}{l}\text { References to riots in Cairo and } \\
\text { Bahrain }\end{array}$ & Wrong country \\
\hline Mauritania & not "Dakar" & $\begin{array}{l}\text { Riots in Dakar, Senegalese and } \\
\text { Mauritanian refugees flee }\end{array}$ & Wrong country \\
\hline Mexico & not "border" & $\begin{array}{l}\text { 06/18 picks up protests in US near } \\
\text { Mexican border }\end{array}$ & Wrong country \\
\hline Mexico & $\begin{array}{l}\text { not "Democratic Revo- } \\
\text { lution" }\end{array}$ & Mexican national election & Diplomatic \\
\hline Mongolia & $\begin{array}{l}\text { not "economic revolu- } \\
\text { tion" or "Revolutionary } \\
\text { Party" }\end{array}$ & & Incorrect usage \\
\hline $\begin{array}{l}\text { Montenegro, Rep. } \\
\text { of }\end{array}$ & not "Kremlin" & MNE bids to join NATO & Wrong country \\
\hline North Macedonia & $\begin{array}{l}\text { not ("Macedonia is } \\
\text { Greece") }\end{array}$ & $\begin{array}{l}01 / 19 \text { picks up protests in Greece } \\
\text { over name change }\end{array}$ & Wrong country \\
\hline Norway & not "Nobel" & $\begin{array}{l}10 / 20 \text { protests over Nobel peace } \\
\text { prize }\end{array}$ & Country-Specific \\
\hline
\end{tabular}




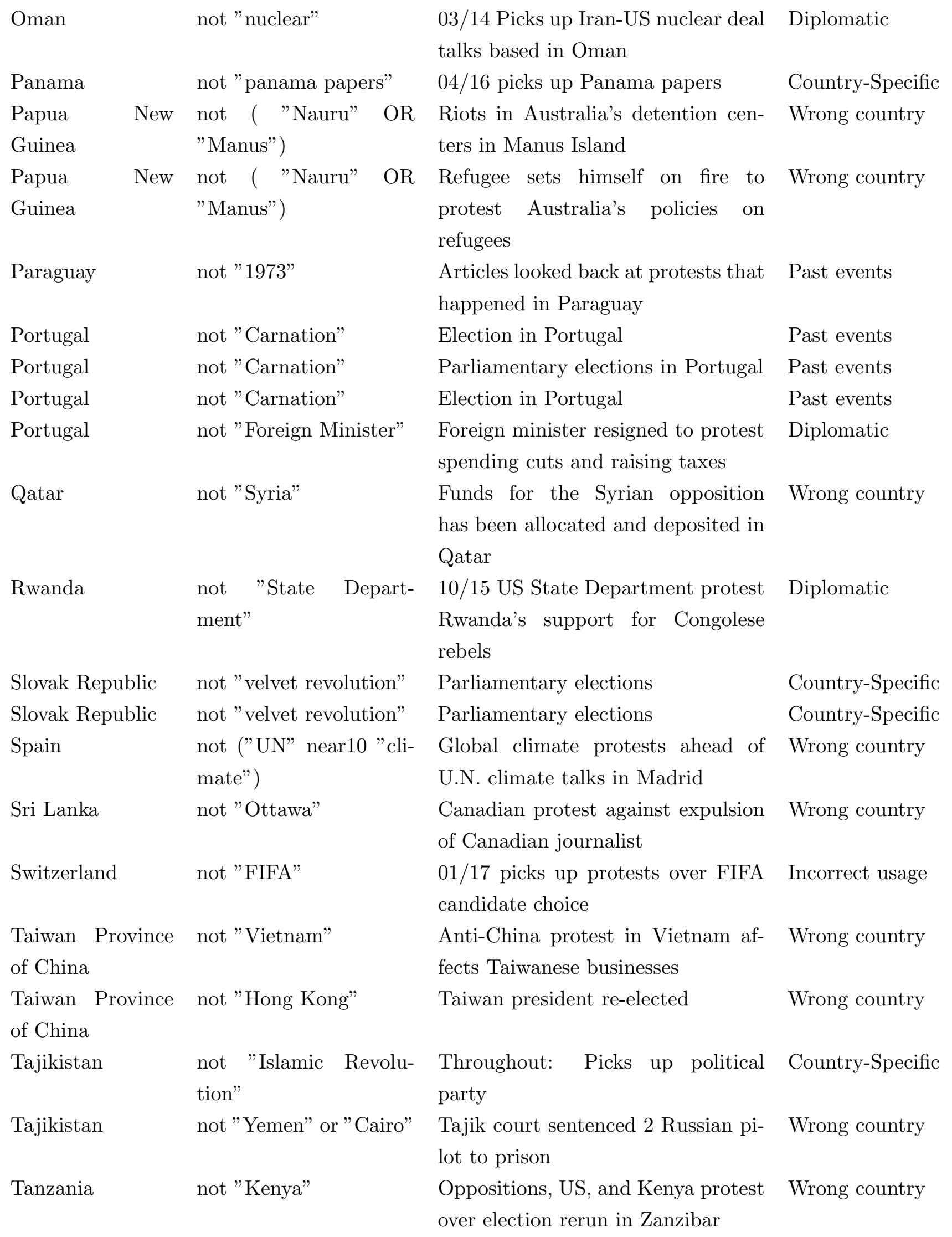




$\begin{array}{llll}\text { Ukraine } & \begin{array}{l}\text { not "military aid" or } \\ \text { impeach* or "House In- }\end{array} & \text { about Trump impeachment } & \\ & \text { telligence Committee" } & & \\ & & 02 / 06 \text { : Picks up controversy over } & \text { Incorrect usage } \\ \text { United Arab Emi- } & \text { not "DPW" } & \text { Dubai Port World purchases } & \\ \text { rates } & & 12 / 11 \text { picks up protests at British } & \text { Wrong country } \\ \text { United Kingdom } & \text { not "Embassy" } & \text { Embassy in Tehran } & \\ & & \text { Throughout picks up "revolution" } & \text { Country-Specific } \\ \text { Vietnam } & \text { not "revolution" } & \text { for Party events } & \\ & & \text { Protests over fish deaths due to Tai- } & \text { Incorrect usage } \\ \text { Vietnam } & \text { not "Obama" } & \text { wanese steel plant } & \\ & & 08 / 18 \text { picking up diplomatic inci- Diplomatic } \\ \text { Zambia } & \text { not "Zimbabwe" } & \text { dent with Zimbabwe } & \\ & & \end{array}$

Table 10: Search modifications and reasons

\section{B Other narrative approaches}

In this appendix we compare the RSUI to narrative sources for five further times and places:the "people power" revolution in the Philippines in 1986; the pro-democracy Korean "June struggle" of 1987; protests surrounding the impeachment of President Park of Korea in 2016; and unrest in five Middle-Eastern countries between 1999 and 2019 (this overlaps with the analysis of the Arab Uprisings in the main text but uses an alternative narrative source).

\section{B.1 Philippines, 1986}

In 1986, mass protests and a contested election resulted in the resignation of longtime Filipino president Fernando Marcos, known as the "people power" or "EDSA" revolution. Our main narrative source for this is Schock (1999), a peer-reviewed article comparing social movements in the Philippines and Myanmar.

The events of this period occur within a relatively short period of time. Schock documents "rising protests" in 1985 (prior to the start of the RSUI) following the assassination of opposition leader Benigno Aquino. In November 1985, President Marcos announced snap elections for 7 February the following year. These were marred by allegations of violence and fraud, and a week later results were rejected by the new opposition leader, Corazon Aquino (Benigno's wife). The following days saw an attempted coup, strong condemnation of the incumbent regime by several influential cardinals, and mass military defections to the opposition. By 25 February, Corazon Aquino had been sworn in and the Marcos family had departed into exile.

The rapid pace of events during this episode is reflected in singular peak in the appropriate month in the RSUI, February 1986, which s also identified as an RSUI event (Figures 21 and 22). 


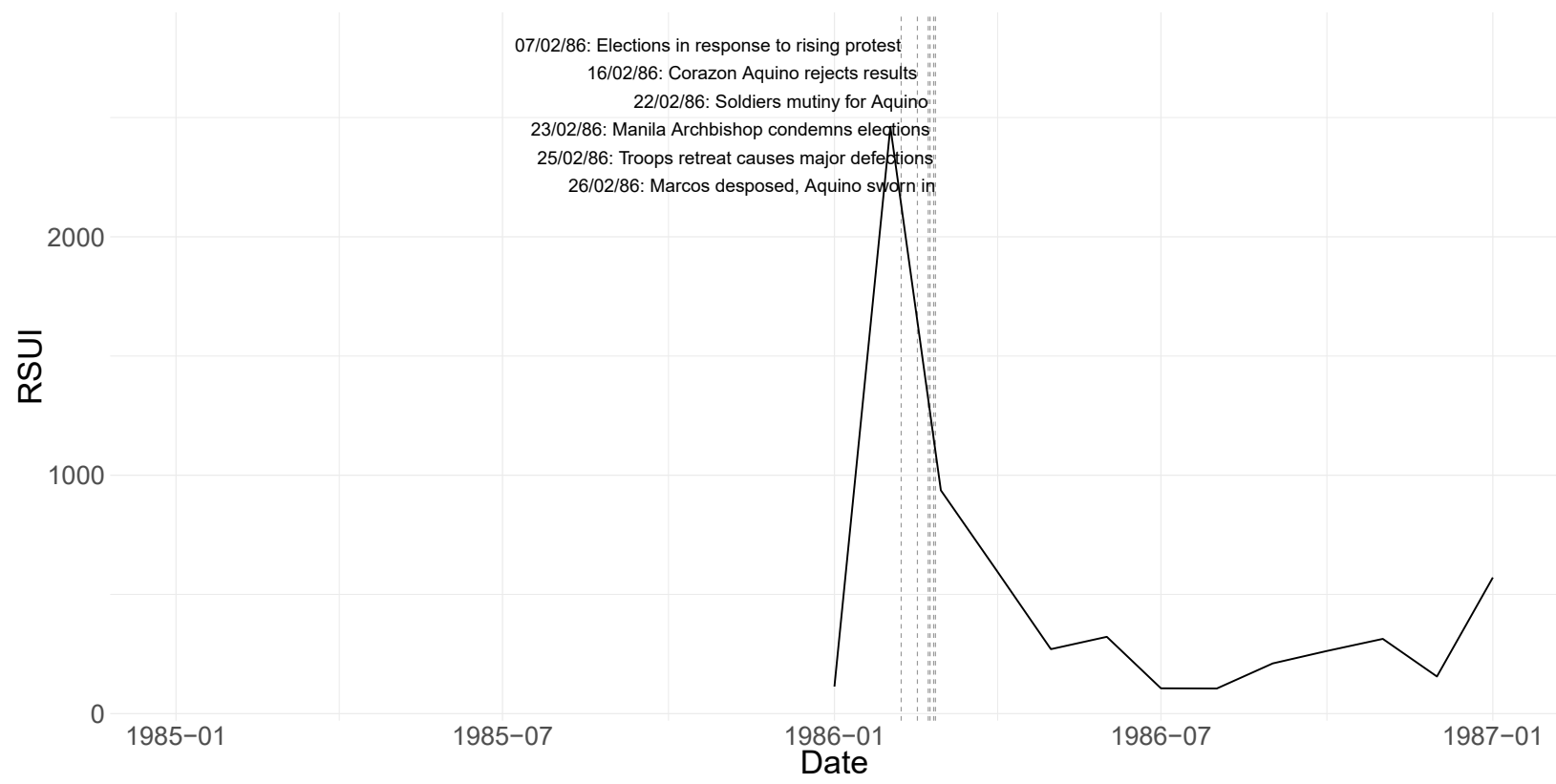

Figure 21: Philippines, January 1986 - January 1987: Major events identified by Schock (1999)

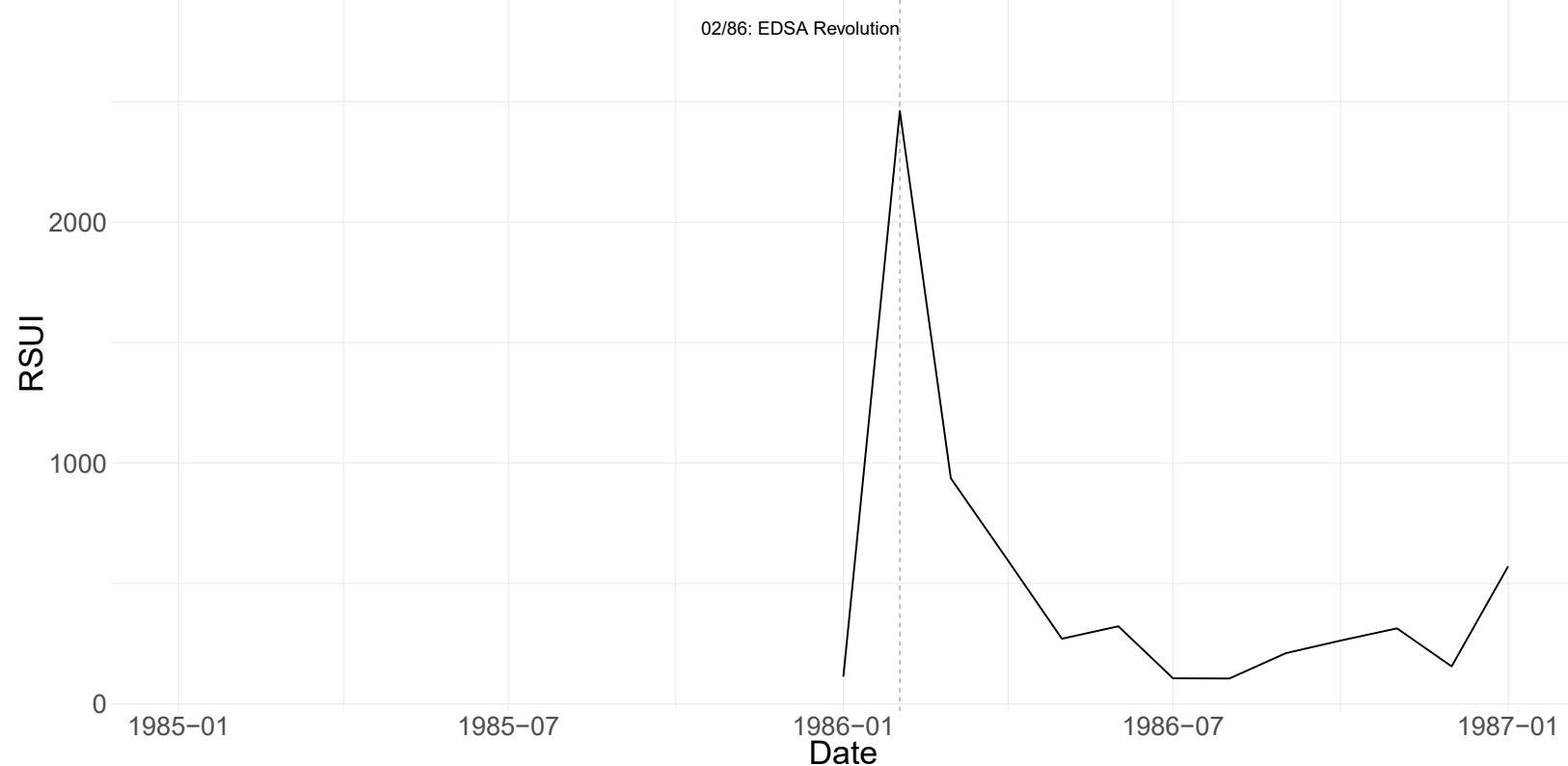

Figure 22: Philippines, January 1986 - January 1987: Major events identified from RSUI event coding 


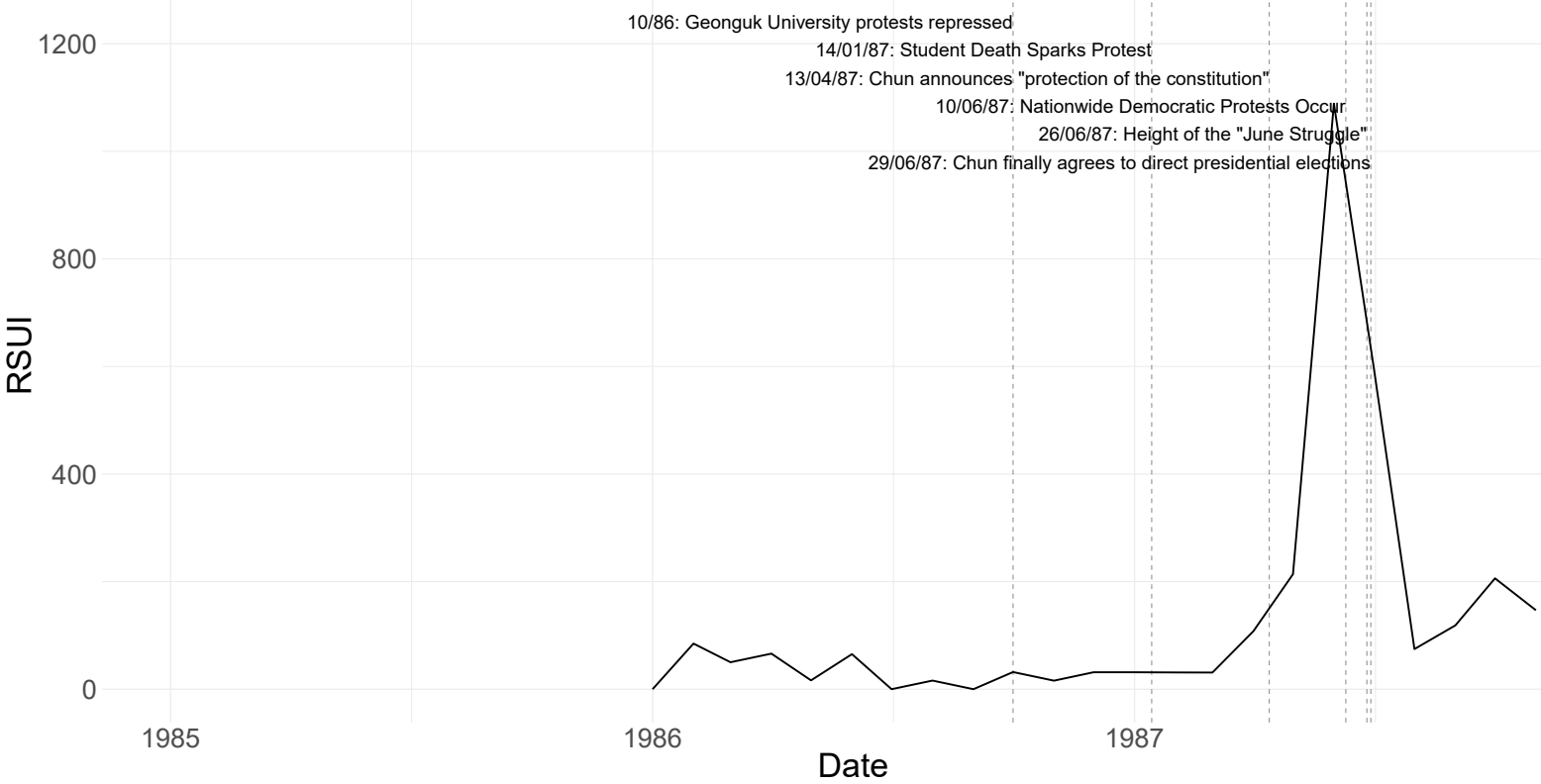

Figure 23: Korea, January 1986 - November 1987: Major events identified by Choe \& Kim (2012)

\section{B.2 Korea, 1986-1987}

Our primary source for the events of the "June struggle" of 1987 in Korea is Choe and Kim (2012), a peer-reviewed article published in a cultural studies journal. The primary focus is on understanding the multiple democratization movements in Korea from 1980-1987 and so includes an extended history of the events leading up to the June struggle. These authors identify an intensifying circle of protests and repression starting with the student protests at Geonguk University in October 1986. The torture and death of a student demonstrator in January 1987 while in government custody was initially suppressed, but once information became public in late May, mass public protests started on 10 June and grew with each passing week, peaking with the largest demonstrations on 26 June. Three days later, President Chun agreed to free elections and his nominated successor General Roh acceded to the protestors' major demand. Protests subsequently subsided and largely peaceful elections took place in December 1987.

The RSUI reflects these events, showing a very pronounced peak in exactly June 1987, and a corresponding RSUI-implied event. Combined with the evidence presented in Section B.1, this illustrates how the index can identify precisely to the month very fast-moving protests events, event very early in the sample. 


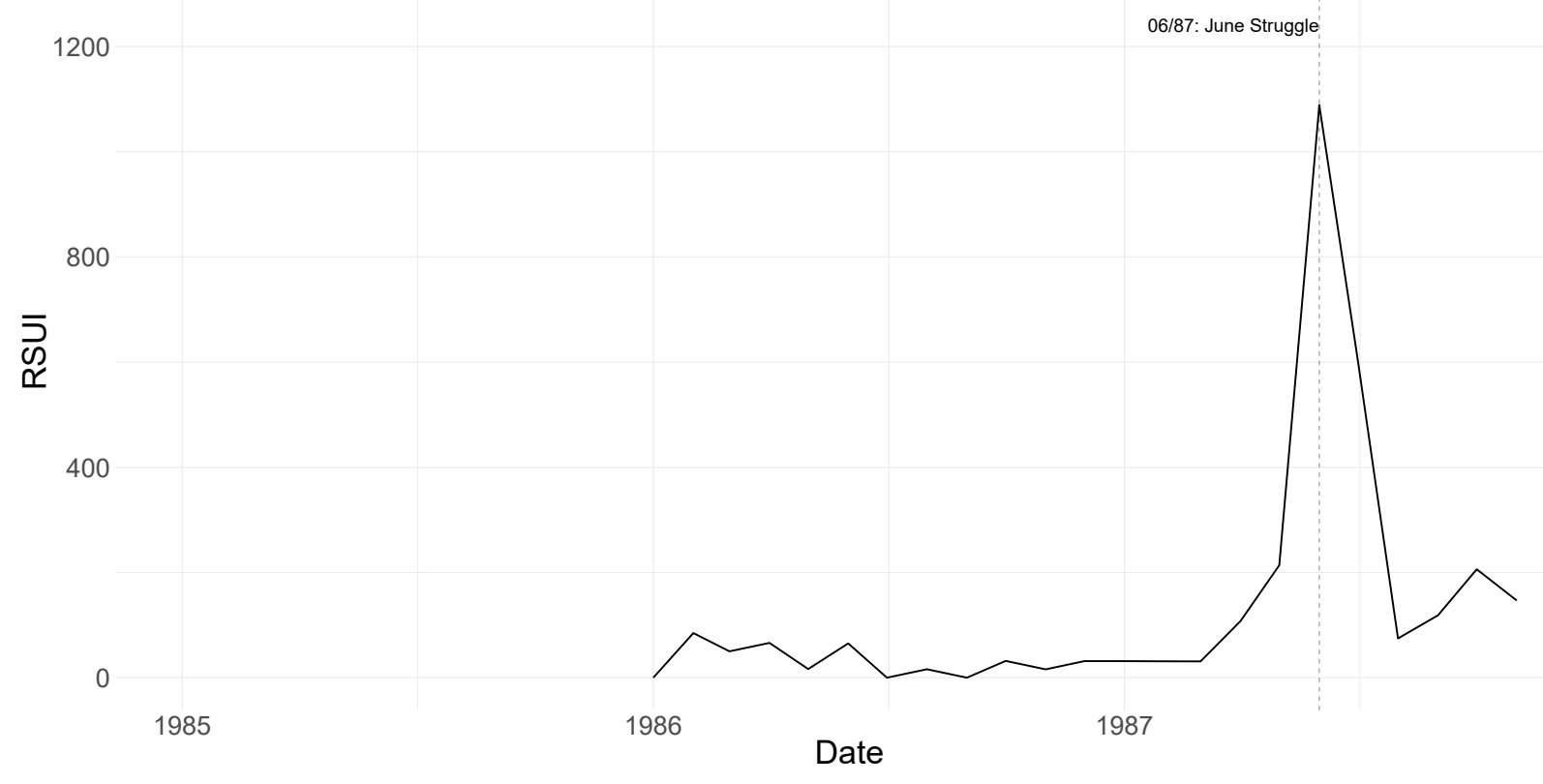

Figure 24: Korea, January 1986 - November 1987: Major events identified from RSUI event coding 


\section{B.2.1 The End of Apartheid}

The final test case for the RSUI is the end of the Apartheid regime in South Africa. For this episode we compare our approach to two in-depth analyses. One is a peer-reviewed article from a political science journal, Klopp and Zuern (2007), who provide a narrative account of the democratization of South Africa with a daily record of major events. The other, Waldmeir (1997), is a book-length journalistic account of the transition away from Apartheid based on interviews with major figures involved and which provides a monthly timeline of major events.

The end of Apartheid was a unpredictable and fast-moving event, and so the two external sources identify a large number of major events in this period. For the sake of transparency Figure 25 includes all those mentioned by the two external sources. Many events are important, but principally political rather than describing actual unrest. We therefore highlight with asterisks descriptions which are more plausibly described as social unrest. Nevertheless, by including all the events in our sources we allow the reader to assess for themselves whether this distinction is reasonable, and to form their own opinion on whether non-unrest events are being (wrongly) reflected in the index.

We interpret Figure 25 as convincing evidence that the RSUI reflects well the narrative histories of Waldmeir (1997) and Klopp and Zuern (2007). The highest two peaks of the index match the two events which bookend the period, both of which were accompanied by massive public demonstrations: the release of Nelson Mandela in February 1990 and the first non-racial elections in late March 1994 (again, triggering a peak in April due to the monthly frequency). Likewise, key intermediate events which prompted or were due to unrest are also reflected by peaks in the RSUI, including: the deaths of 17 protesters at Sebokeng in March 1990; the breakdown of multi-party talks (CODESA) and mass ANC demonstrations starting in June 1992; the Bisho Massacre in September 1992; and the assassination of Chris Hani (the head of the ANC's armed wing) in April 1993.

The large number of events in these sources also provides an opportunity for several falsifications checks. A number of undoubtedly important but entirely political (i.e. not social unrest) events barely register on the RSUI. These include: the start of multi-party talks in December 1990, the Record of Understanding which restarted negotiations following the failure of CODESA; and agreements on the constitution and governance prior to the 1994 election.

Figure 26 presents the same period with RSUI-implied events overlaid. This again highlights that the event coding is accurate but a little conservative - identifying arguably the most important events of the period to the correct month, but only identifying three events.

\section{B.2.2 Korea 2016-2017}

The protests surrounding the impeachment of President Park are often known as the "Candlelight revolution". In late October 2016, reports emerged of abuse of power by one of the President's aides. This, and subsequent revelations, led to mass protests during November 2016. These events are documented in Kim (2017), a peer-reviewed article in a political science journal. This is reflects 


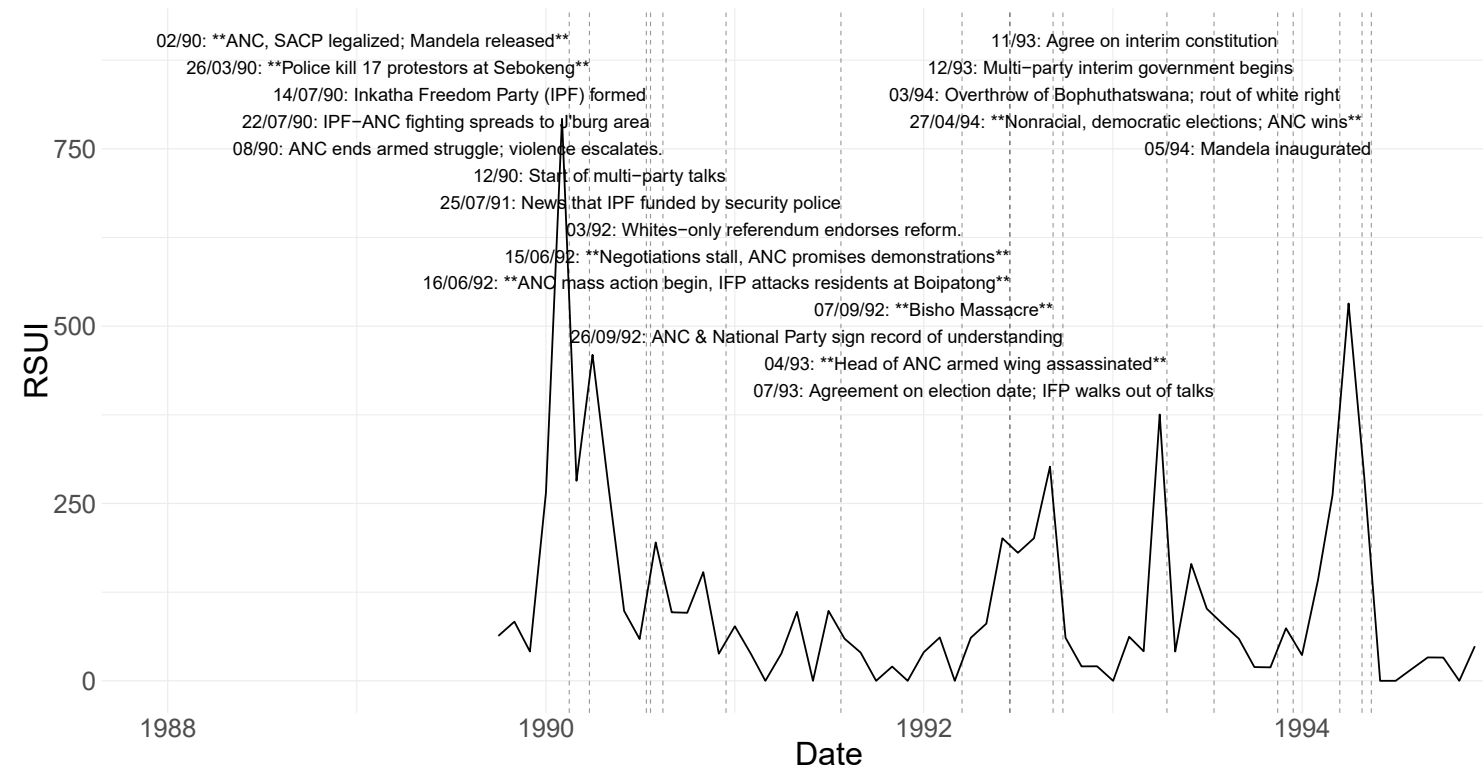

Figure 25: South Africa: Major events identified by Waldmeir (1997) and Klopp \& Zuern (2007), October 1989-December 1994. Asterisks denote likely unrest events.

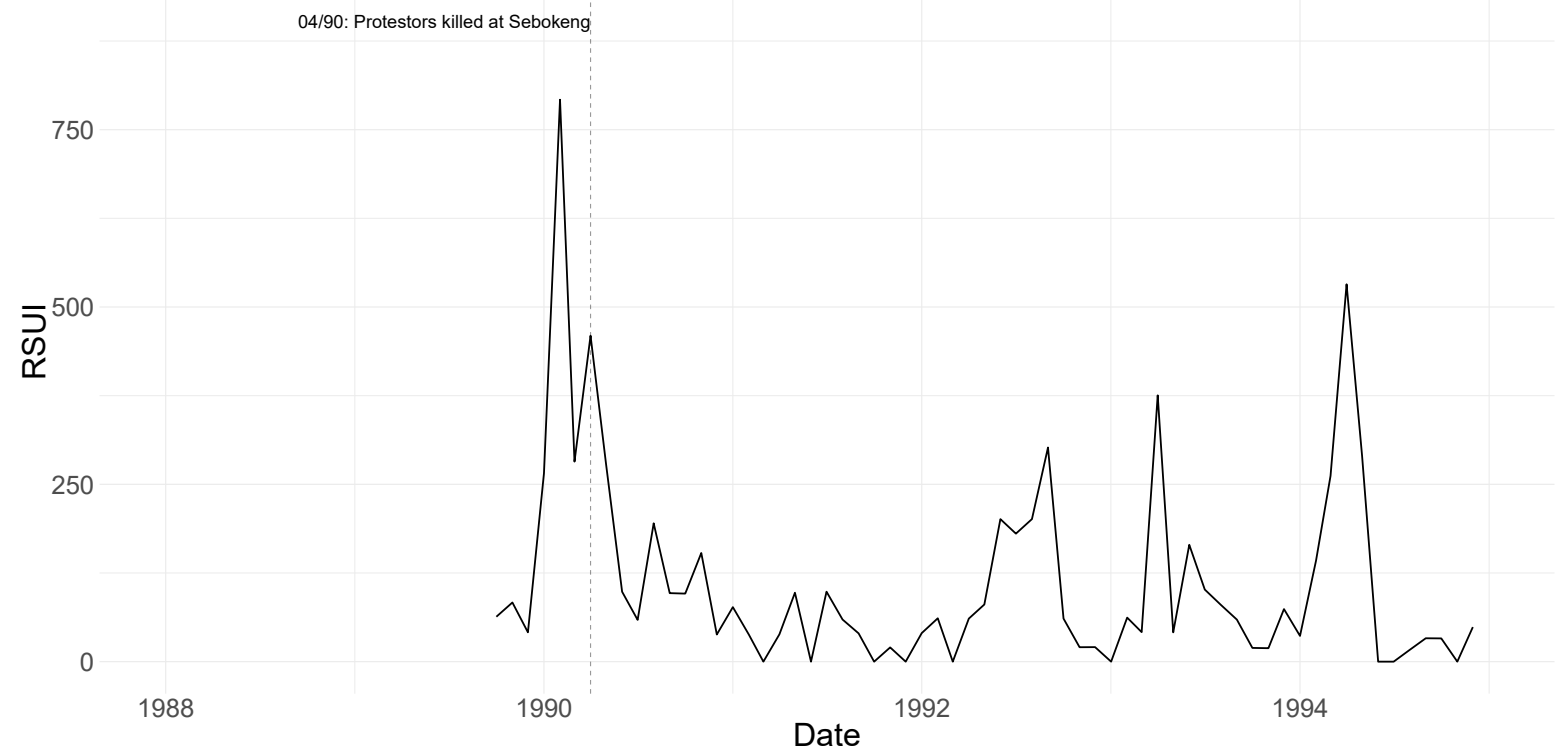

Figure 26: South Africa: Major events identified from RSUI event coding, October 1989-December 1994 
in the RSUI, which picks up sharply in November, a month coded as an RSUI event (see Figure 28).

Protests continued through late 2016 (identified by Kim (2017) as reaching their "heights" in December") before easing when the President was suspended by Parliament for 180 days. This suspension corresponded with an easing in tensions while the Korean Constitutional Court heard argument and evidence. However, the verdict in March 2017 corresponded with further large protests, resulting in three deaths. This event is also coded as an RUI event.

The subsequent elections in May 2017 are also reflected in an increase in the RSUI. However, this is not coded as an RSUI event, as it fails our event screening criteria. There are no contemporaneous reports of protest or other forms of social unrest in this month. Instead, matching articles include mention of prior protests as context for the current elections. Thus, there is no RUSI event recorded despite the local spike.

\section{B.3 Middle East, 1999-2019}

In addition to our analysis of the Arab Uprisings of 2011, we also compare our results to a broader analysis of unrest in the Middle East between 1999 and 2019. For this, we use timelines assembled by the United States Institute of Peace ("USIP") of five Middle Eastern countries (Egypt, Iran, Iraq, Libya, and Tunisia) between January 1999 and June 2019. The events identified in the USIP timelines are shown as vertical lines in Figure 29. The period and countries are identical to those in Figure 30, which includes the RSUI event codings.

For the four Arabic-speaking countries, the time series is dominated by the Arab uprisings of 2011. Accordingly, the initial spikes in the RSUI in early 2011 in each of these five countries coincides with the initial round of protests as identified by USIP. In Tunisia where the Arab Spring started, protests began spreading after the self-immolation on 17 December 2010 and subsequent death on 4 January 2011 of Mohamed Bouazizi. This is reflected in the RSUI-implied event in January 2011. In Egypt where the first wave of unrest started a few weeks later on January 25th, the first RSUI-implied event of the Arab Spring in Egypt is dated to February 2011. Similarly, the RSUI dates the start of the Arab Spring in Iraq and Libya to be February 2011 and Syria to be April 2011, which coincides with the external timeline.

The RSUI also captures civil unrest documented by the USIP timelines in the period following the initial outbreak of the Arab Uprisings, with secondary protests coinciding with spikes in the Index, and major turning points of the revolution matching the implied events. For instance, key protest episodes in the USIP timeline for Egypt, such as post-election unrest in June 2012, protests following President Morsi's decree of personal immunity, and his eventual overthrow in July 2013 all agree with RSUI-implied events.

In addition to the four narratives Arabic-speaking countries, the USIP also provides a timeline of recent events for Iran. Similarly, the RSUI does a good job of capturing key unrest episodes in that country, including the widespread unrest in Janurary 2018 and the June 2009 Green Movement protest, described by USIP as "ne of the most serious challenge to the theocracy of the revolution". 


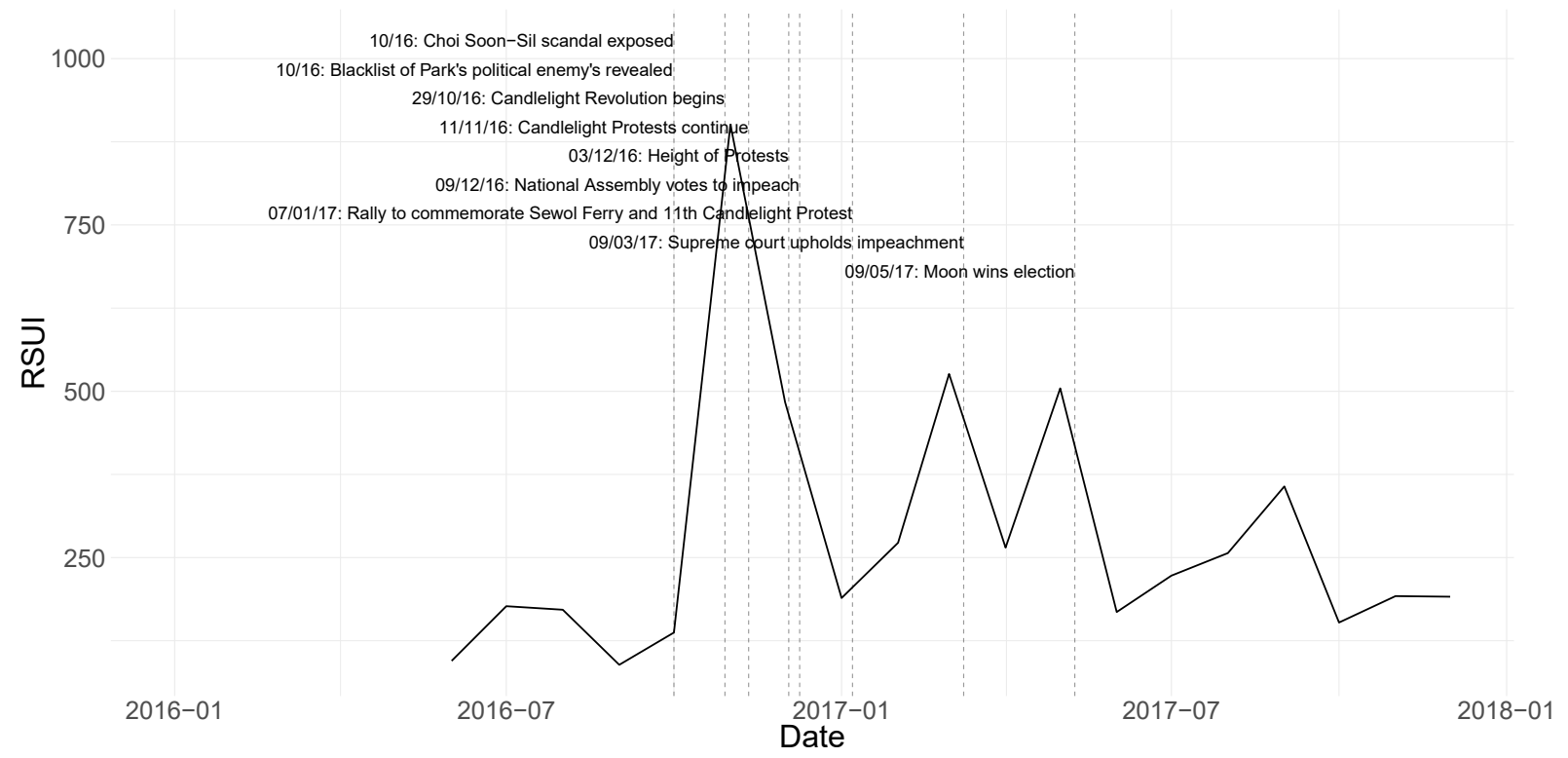

Figure 27: Korea: Major events identified by Kim (2017), June 2016-December 2017

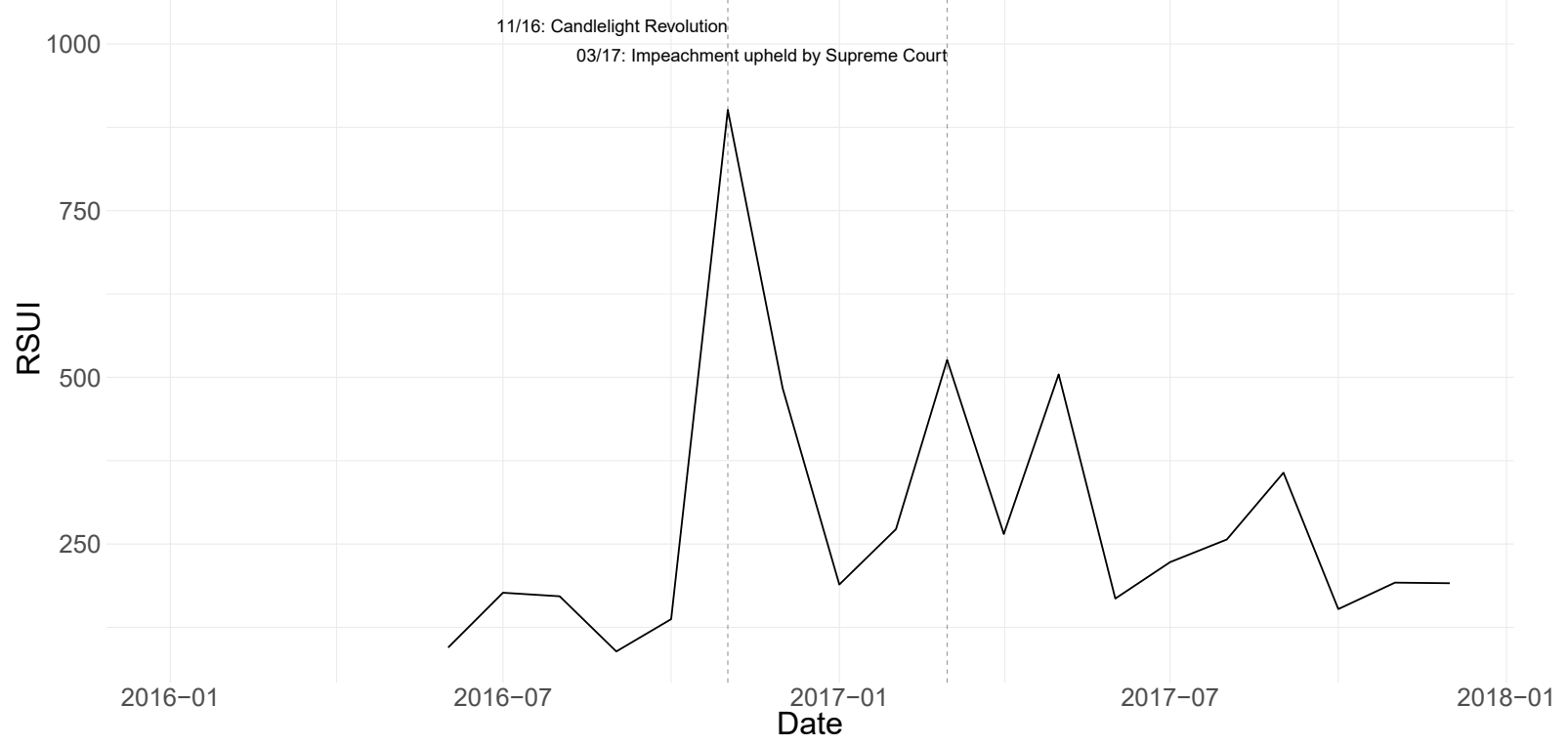

Figure 28: Korea: Major events identified from RSUI event coding, June 2016-December 2017 
There are only three major differences between the RSUI events and the USIP timelines. First, the RSUI-implied events include the parliamentary and presidential election in Tunisia in 2014 and presidential elections in June 2013 in Iran. It is not clear why these are omitted from the USIP timelines. Second, the USIP captures more protest events than our event coding, simply because it identifies separate within-month events, such as demonstrations between April 1 and April 12 demanding Mubarak's prosecution and faster reform in Egypt. As discussed in the main text, however, these relatively smaller unrest episodes are reflected in elevated levels of the index, while key episodes are identified as events. The event coding is somewhat conservative as we face a tradeoff between false positives and false negatives. In this study, we opt to minimize the former. Finally, there are three major RSUI-implied events that are not picked up by USIP: August 2011 and November 2011 in Libya, and July 2018 in Iraq. The events in Libya reflect the onset of the civil war there. In Iraq, the USIP dates the Basra protests "over unemployment, shortages of clean water and electricity, and widespread corruption" to September 2018. However, those protests appear to be a continuation of those a few months earlier, triggered by electricity cuts on July 8th, in line with our event dating. 


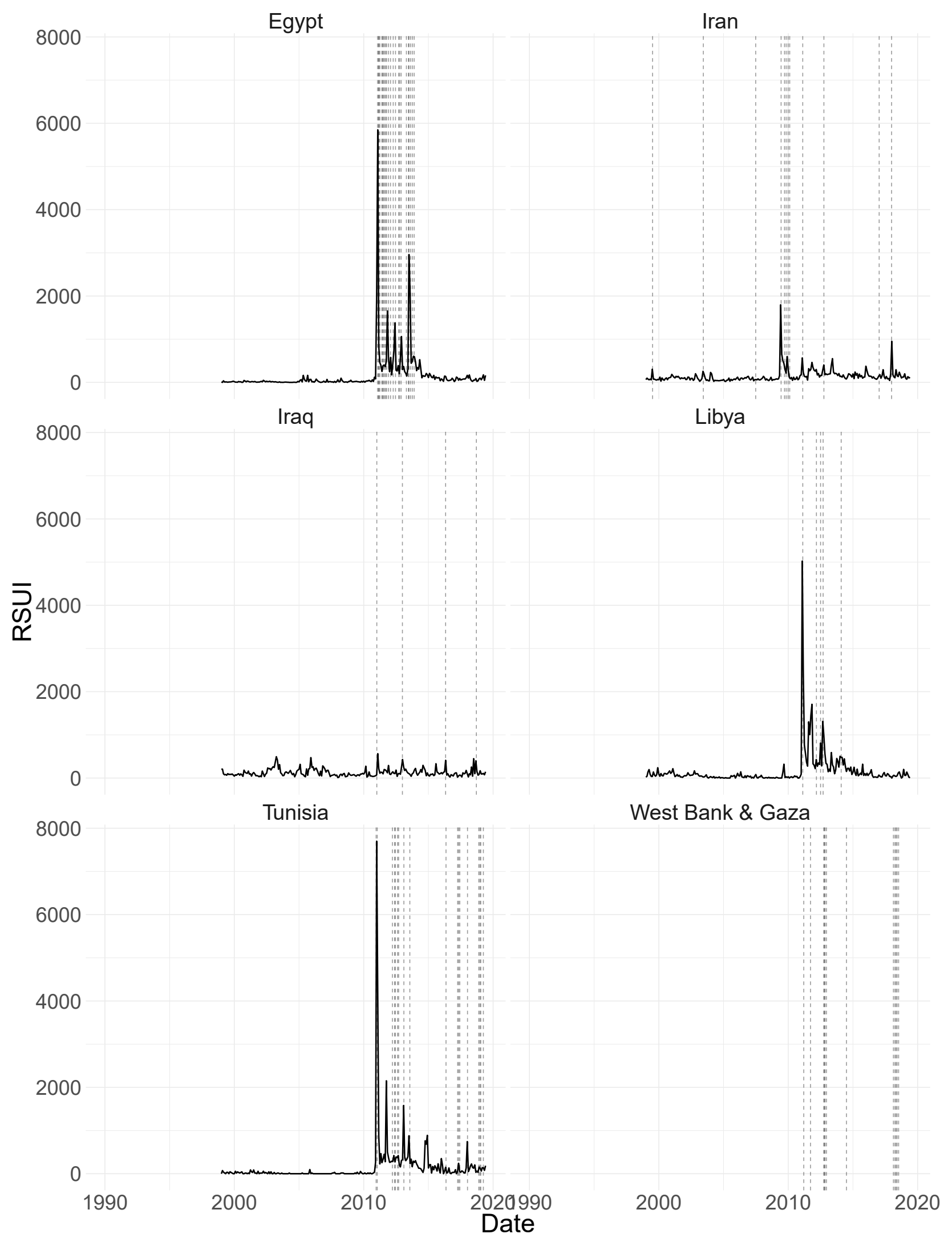

Figure 29: Middle East, January 1999 - June 2019: Major events identified by USIP 


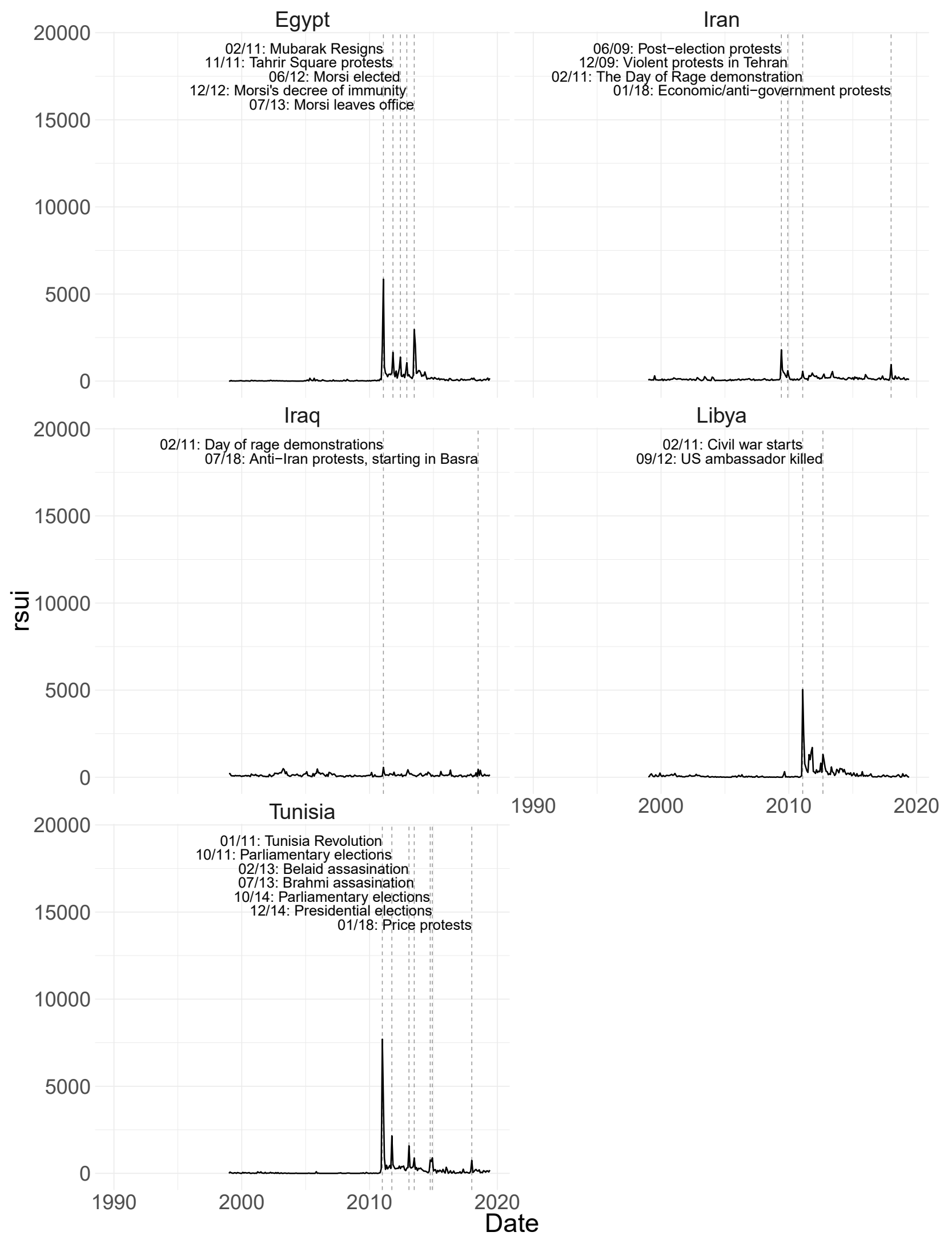

Figure 30: Middle East, January 1999 - June 2019: Major events identified from RSUI event coding 


\section{Comparison to other measures}

Here we compare the RSUI to other commonly used measures of social unrest. The first is the Armed Conflict Location and Event Database (ACLED) which includes counts of individual demonstrations and riots at the country level. While coverage has expanded dramatically since 2015, the primary focus of this data source is on African countries, of which a sample of 27 have data starting in 1998. We therefore create an index for each of these countries analogous to the RSUI, summing the number of events in each month and rescaling so that the index averages to 100 since 2000, which we combine into a single summary measure by taking a simple average across countries in each month. This is presented in Figure 31, along with the average RSUI for the same 27 countries (also rescaled to average 100 over the same time period).

Despite measuring different phenomena using different methodologies, there is broad agreement between the two measures. Both are relatively low in the first decade of the 2000s and then exhibit a substantial and persistent increase starting in 2011. Within this, both series also show broad qualitative agreement in the last few years, with a rise in unrest around 2015, a subsequent decline during 2016-2017 and a pick-up since. At an annual frequency, the correlation is 0.7. At a monthly frequency, the two indices unsurprisingly diverge a little more, with a correlation nearer to one half.

The second alternate data source is the Cross-National Time-Series Data (CNTSD) database by Banks and Wilson (2020), used in other studies of social unrest and economics, such as [Fuceri paper]. This has very broad coverage, including 117 countries starting in 1995, but at annual frequency. This index reports the number of riots and anti-government demonstrations, which we sum and compute country indices. From these, we compute a simple average to give an aggregate annual index.

This index is reported in Figure 32. The CNTS seems to show an almost monotonic increase in unrest events from around 2009 onward with very little variation prior. This is somewhat hard to reconcile with the evidence from the RSUI and the ACLED. Unfortunately, there is no way to further interrogate the data to uncover which particular events are driving this. Moreover, given the annual frequency of the data one cannot easily make an educated guess as to the source of this increase. One possible explanation is that the CNTS uses a raw count of reports of unrest. If media coverage overall has increased during this time (perhaps as a result of reduced cost of printing or increased interest in foreign news) then such a pattern might emerge. As an extra cross-check, we also compare to the average rate of RSUI-implied events. This does not seem to explain the behavior of the CNTS index any better, with increases in the early 2000s and 2010s apparently uncorrelated with the CNTS index.

As fluctuations in long-term multi-country averages may reflect changes in composition and measurement over long periods of time, we also compare the RSUI to the ACLED and CNTS data during specific events for which we have already validated the RSUI using narrative data. To this end, Figures 33-36 compare the CNTS and (where available) ACLED data to the RSUI. Here, the agreement between the various measures is very good. Note in particular the close alignment between the timing of spikes in the RSUI and the ACLED index during times of extreme stress. 


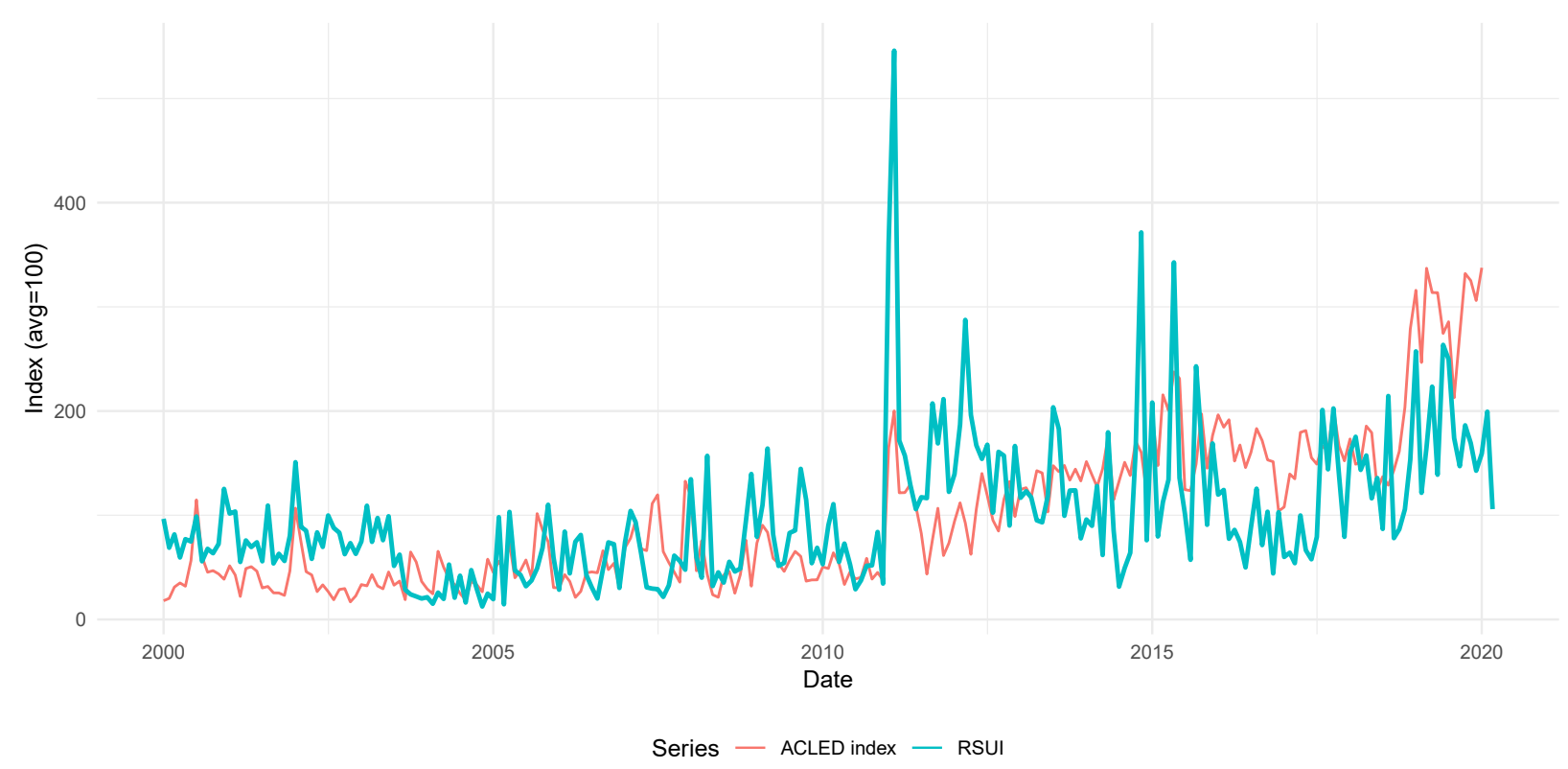

Figure 31: RSUI vs. ACLED, 27 countries, January 2000 - March 2020, simple average

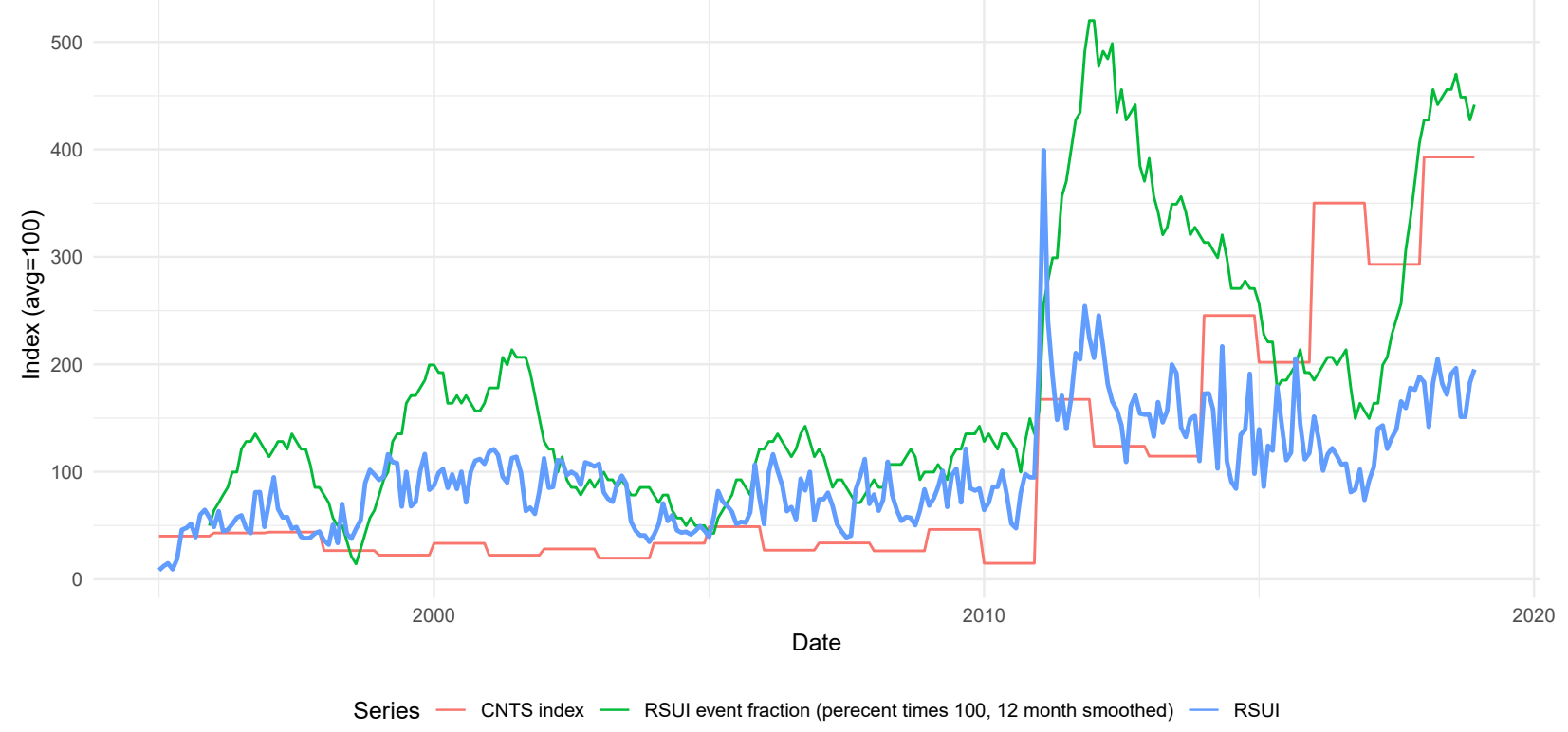

Figure 32: RSUI vs. CNTS, 117 countries, January 1995 - March 2020, simple average 


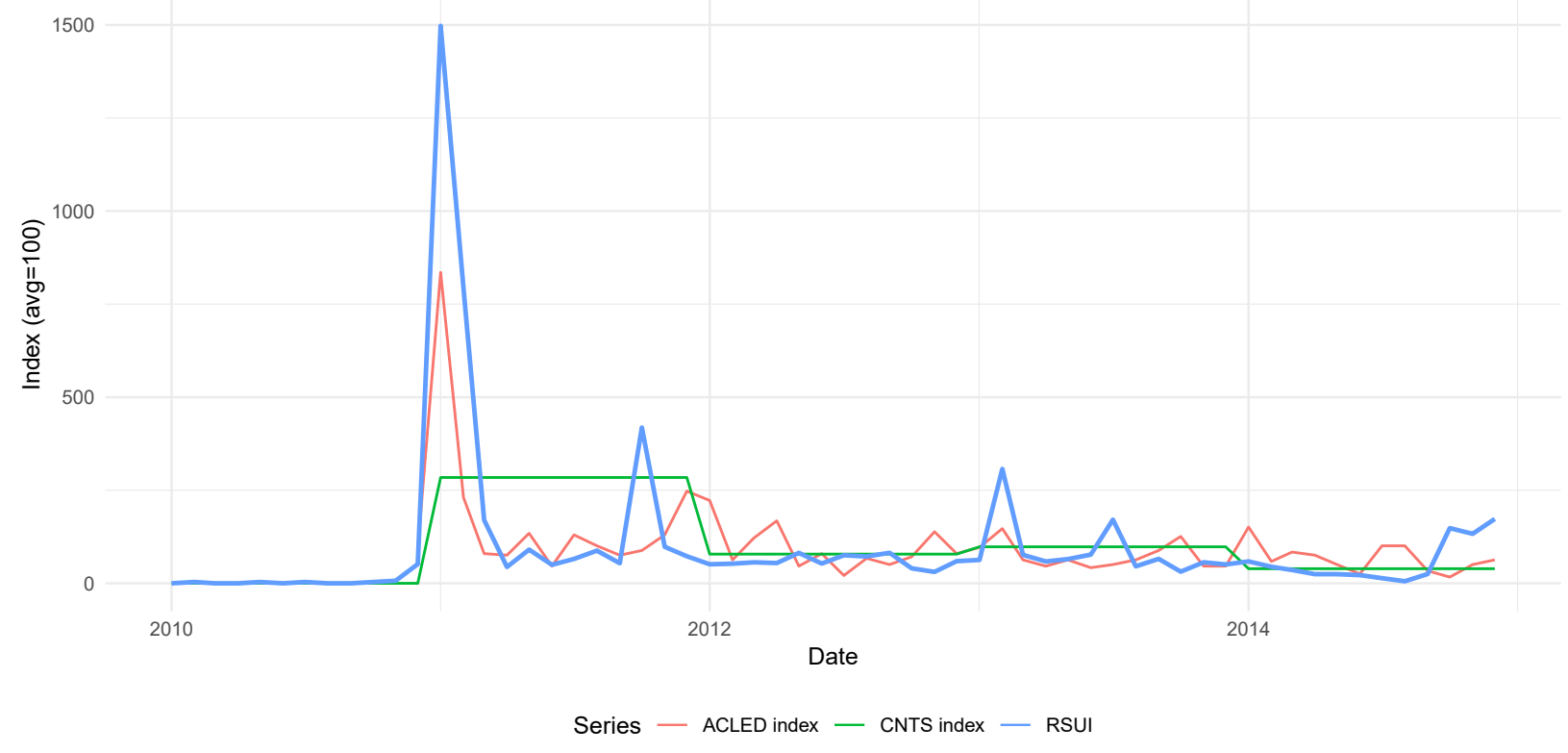

Figure 33: RSUI vs. ACLED \& CNTS, Tunisia, 2000 - 2014



Figure 34: RSUI vs. ACLED \& CNTS, Egypt, 2000 - 2014 


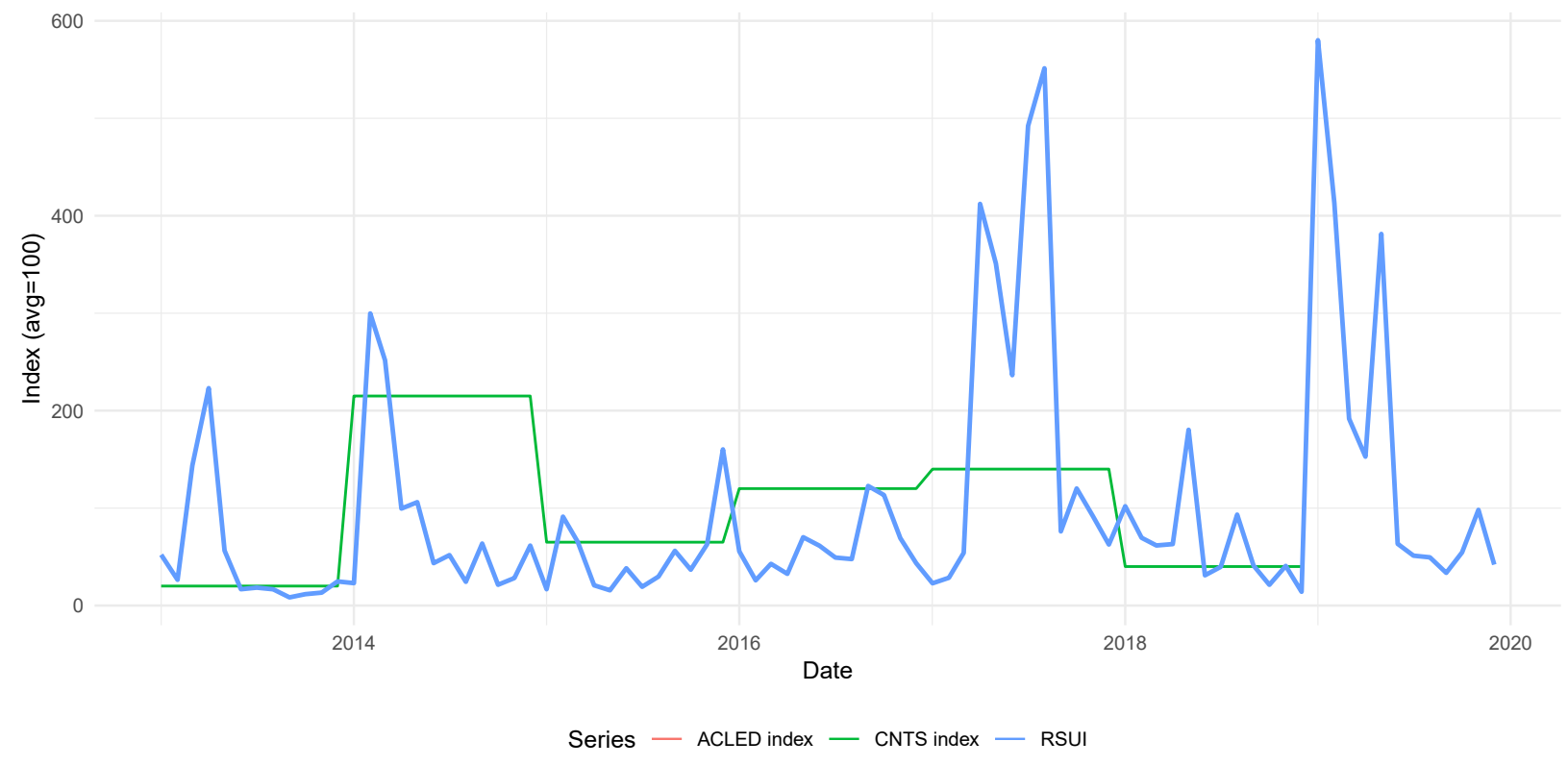

Figure 35: RSUI vs. CNTS, Venezuela, 2013 - 2019

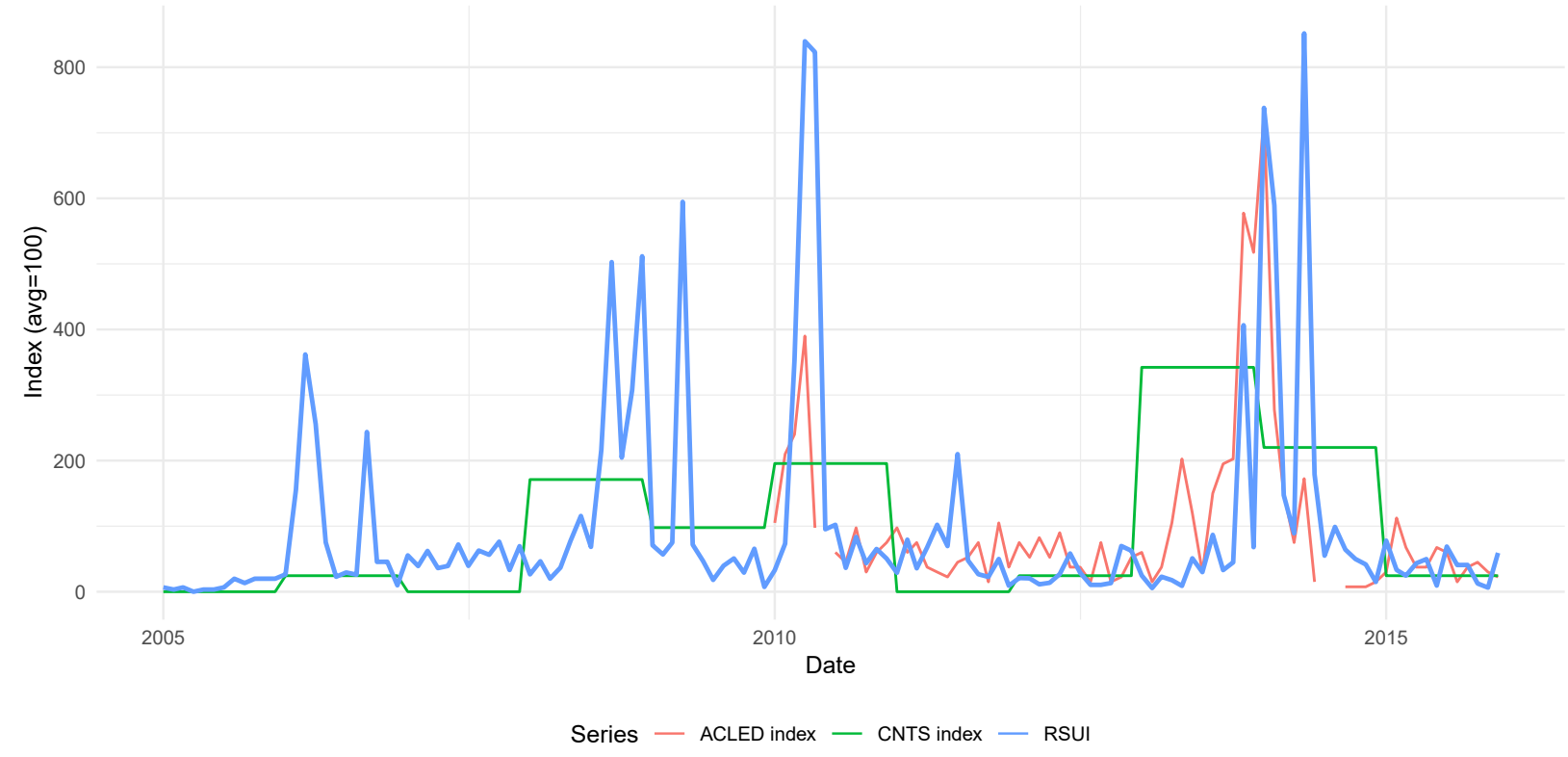

Figure 36: RSUI vs. ACLED \& CNTS, Thailand, 2005 - 2015 


\section{Robustness of Statistical Properties}

Figures 37 and 38 show two further robustness checks for the estimates of the cross-sectional density of the RSUI. The first presents country-specific estimates of the two parameters, compared to their full-sample estimates. Here, the same estimation exercise is conducted using only the RSUI index for a given country. Error bars show two-standard-error ranges percent confidence intervals. These show that in most cases we cannot reject the hypothesis that the country-specific estimates equal the full-sample ones. The full-sample estimates fall within the country-specific in over 80 and 90 percent of countries for the estimates of $a$ and $b$ respectively. This is somewhat surprising, particularly given the scope for cross-country variation in media coverage and patterns of unrest. This further justifies the interpretations of the units of the RSUI given in Section 5.1.

Figure 38 reports the same estimates as the value of the arbitrary cutoff $\bar{m}$ changes. Changing $\bar{m}$ has a mechanical impact on $a$, proportionate to $1 / a$, and so panel (a) shows estimates transformed into this space (with standard errors computed via the delta method). The parameter $a$ is reasonably stable, tracking the full-sample-implied value for $1 / a$ reasonably closely. However,

the estimate for $b$ - arguably more important for the interpretation of the RSUI units - is very stable. In fact, the standard error for $b$ actually decreases despite the reduction in sample size as $\bar{m}$ rises. We interpret this as evidence that the RSUI is particularly informative around major events. There may be considerable noise when there is little activity in a given country. But when a large event of unrest occurs, the signal becomes increasingly precise. As a result, the upper tail of the distribution of RSUI values is particularly easy to interpret. 


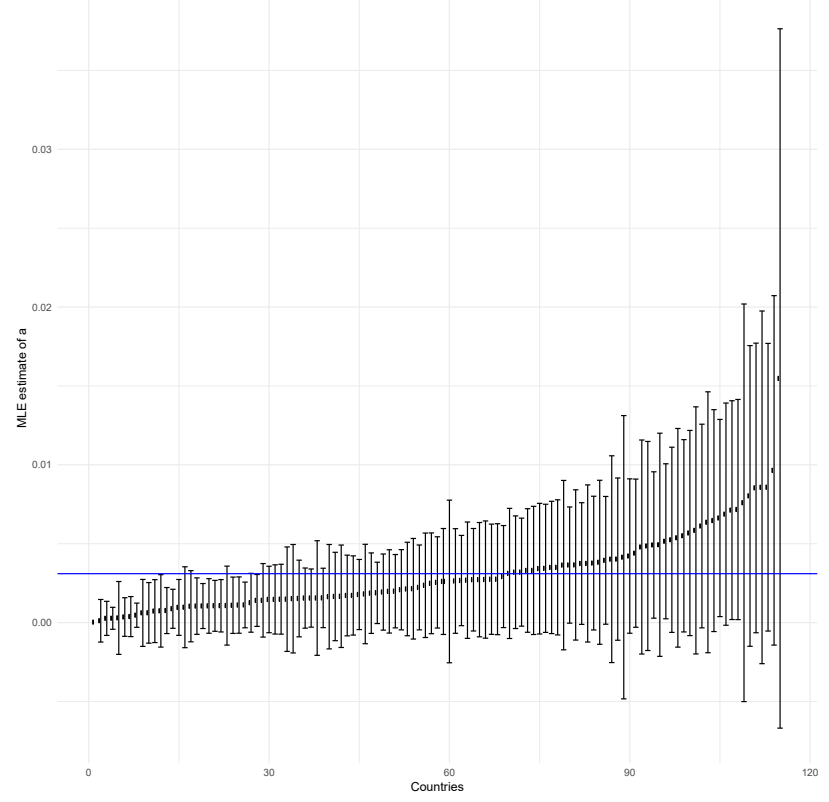

(a) Estimates of $a$

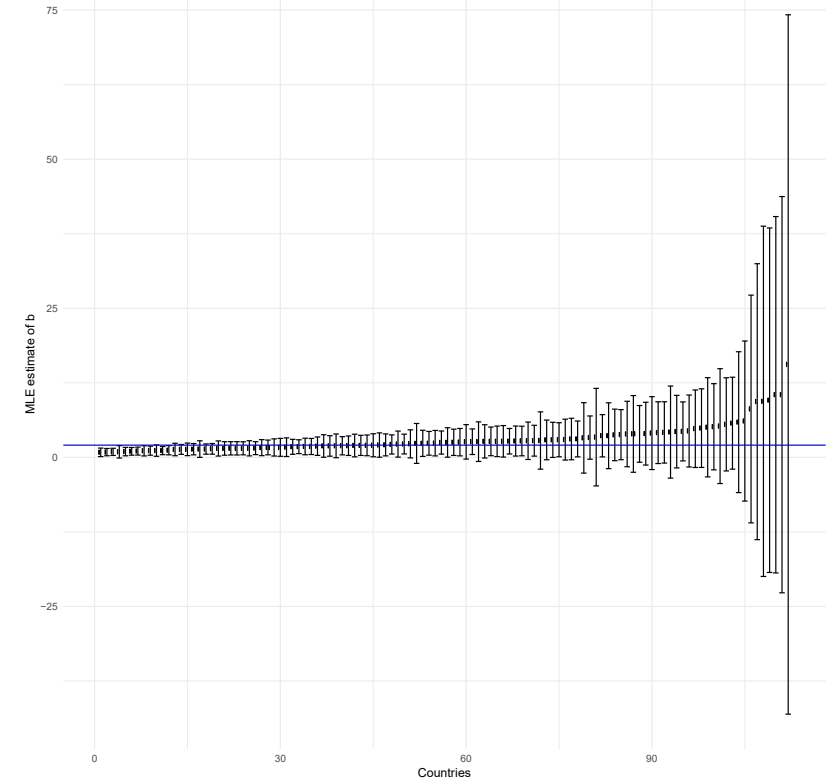

(b) Estimates of $b$

Figure 37: Country-specific parameter estimates. Some countries omitted due to MLE convergence failures. Full-sample estimates shown in blue.

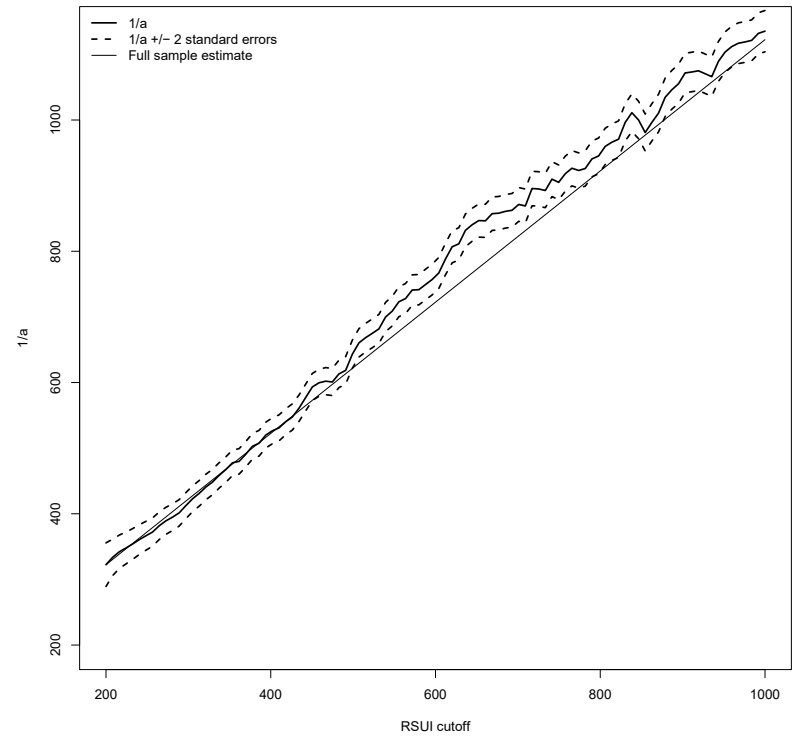

(a) Estimates of $a$

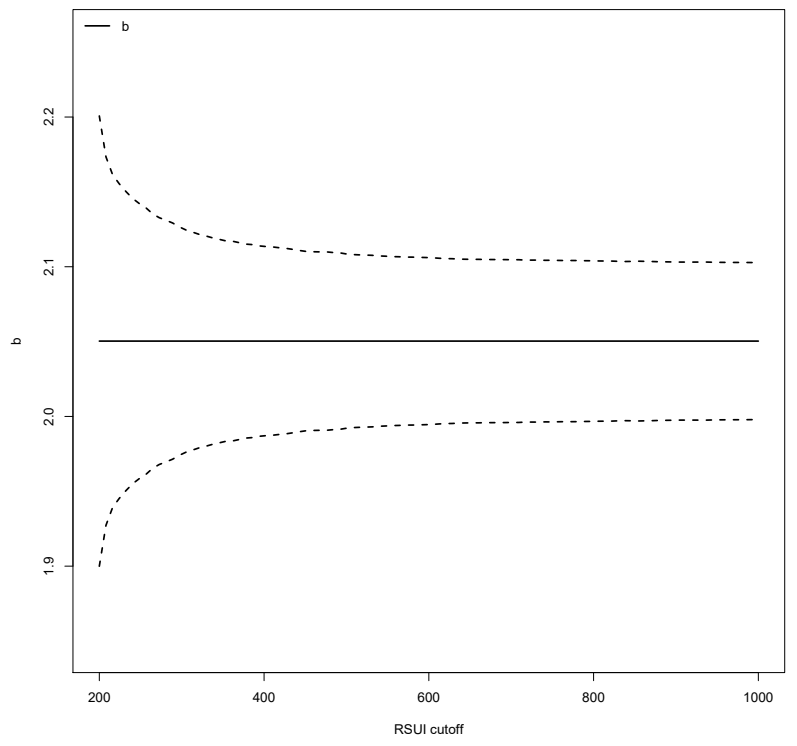

(b) Estimates of $a$

Figure 38: Parameter estimates with changing threshold cutoffs 


\section{E External event descriptions}

\section{E.1 Arab Uprisings}

\begin{tabular}{|c|c|c|}
\hline Country & Date & Description \\
\hline Bahrain & 2011-02-14 & Protests start in Bahrain. \\
\hline Bahrain & 2011-03-14 & $\begin{array}{l}\text { Saudi Arabia sends armored columns into Bahrain. Security forces crush } \\
\text { the uprising, carrying out mass arrests within a few days. Bahrain's king } \\
\text { declares martial law. The monument in Pearl Square, the uprising's } \\
\text { heart, is razed. }\end{array}$ \\
\hline Egypt & 2011-01-25 & Egyptian protests start. \\
\hline Egypt & 2011-01-28 & $\begin{array}{l}\text { Egypt's Friday of Anger. Protestors battle police and win control of } \\
\text { Tahrir Square in Cairo. Similar battles in other cities across Egypt. }\end{array}$ \\
\hline Egypt & 2011-02-11 & $\begin{array}{l}\text { Egypt's President, Hosni Mubarak, steps down. The Supreme Coun- } \\
\text { cil of the Armed Forces takes power, promising a transition to civilian } \\
\text { authority. }\end{array}$ \\
\hline Egypt & 2011-03-19 & $\begin{array}{l}\text { Egypt's first post revolutionary vote, on a constitutional referendum } \\
\text { that could lead to early elections, ends in triumph for the Muslim Broth- } \\
\text { erhood and hints at rising polarization between Islamist and secularist } \\
\text { camps. }\end{array}$ \\
\hline Egypt & 2011-11-01 & $\begin{array}{l}\text { There are more protests and violence in Egypt after the ruling military } \\
\text { council moves to ensure it will play a dominant role even after civilian } \\
\text { government is elected. }\end{array}$ \\
\hline Egypt & 2012-06-01 & $\begin{array}{l}\text { Muhammed Morsi of the Muslim Brotherhood is elected president of } \\
\text { Egypt, narrowly defeating an ally of former president Hosni Mubarak. }\end{array}$ \\
\hline Egypt & 2012-06-30 & $\begin{array}{l}\text { There are huge protests across Egypt against President Muhammed } \\
\text { Morsi. A pro-Islamist sit-in begins in Rabaa Square in Cairo. }\end{array}$ \\
\hline Egypt & 2012-08-14 & $\begin{array}{l}\text { Egyptian security forces clear the two main Islamist protest encamp- } \\
\text { ments, killing about a thousand people and arresting thousands more. } \\
\text { Within weeks, most of the Muslim Brotherhood is jailed. }\end{array}$ \\
\hline Egypt & 2012-11-01 & $\begin{array}{l}\text { The Egyptian president Muhammed Morsi issues a decree temporarily } \\
\text { granting himself broad powers above any court as the guardian of the } \\
\text { revolution. Large-scale protests begin. }\end{array}$ \\
\hline Egypt & 2013-07-03 & $\begin{array}{l}\text { The Egyptian military deposes President Muhammed Morsi and puts } \\
\text { him under arrest in an unknown location. Islamist protests expand and } \\
\text { confrontation with police begin, with dozens shot and killed. }\end{array}$ \\
\hline Egypt & 2014-03-30 & Abdel Fattah al Sisi is elected Egypt's president. \\
\hline Libya & 2011-02-15 & $\begin{array}{l}\text { Libya's first large-scale protests occur in the eastern city of Benghazi. } \\
\text { A police crackdown leads to violent confrontations across Libya. }\end{array}$ \\
\hline
\end{tabular}


Libya 2011-02-27 Libya's National Transitional Council is formed. Two weeks later, France recognizes it as Libya's legitimate government; other countries follow.

Libya 2011-03-17 The United Nations Security Council authorizes military action in Libya. Air strikes begin immediately, with NATO in command.

Libya 2011-08-20 Muammar al Qaddafi, Libya's ruler for forty-two years, is captured and killed by rebels while trying to flee from the coastal city of Sirte.

Libya 2012-09-11 U.S. Ambassador to Libya, J. Christopher Stevens is killed in an attack on American compound in Benghazi following violent protests.

Libya 2012-11-01 Amid rising lawlessness in Libya, nine people are killed in clashes between the military and Islamist militia fighters in Benghazi.

Libya 2014-06-25 Libyan elections are marked by low turnout, and are followed by clashes between followers of outgoing and incoming parliaments. Islamists carry out a coup in Tripoli.

Syria 2011-03-15 Demonstrations start in Syria, triggered by police mistreatment of teenagers arrested in the southern town of Daraa for writing antigovernment graffiti. Protests spread quickly and are met with mass arrests and shootings.

Tunisia 2010-12-17 Mohamed Bouazizi sets himself on fire in Sidi Bouzid, Tunisia. Protests start and spread across Tunisia.

Tunisia 2011-01-14 Tunisia's president, Zine El Abidine Ben Ali, capitulates in the face of rising protests and flees the country with his inner circle.

Tunisia 2011-10-23 Tunisia holds parliamentary elections, the first to take place since the uprising. Ennanda, the Islamist party led by Rached Ghannouchi, wins a plurality and subsequently forms a coalition government

Tunisia 2013-07-25 In Tunis, Mohamed Brahmi is assassinated, making him the second opposition leader to be killed in five months. Protests against the Islamistled government intensify.

Tunisia 2013-09-28 The Tunisian crisis eases. An independent caretaker government takes power and dialogue on a new constitution begins.

Yemen 2011-01-27 The first large-scale protests in Yemen take place.

Yemen 2011-03-18 Gunman aligned with Yemen's government open fire on protestors in the capital, killing at least fifty-two and prompting top military officers to defect. President Ali Abdullah Saleh signals soon afterward that he may step down before the year's end. Much of the country falls out of the government's control.

Yemen 2011-06-03 The Yemeni President Ali Abdullah Saleh is seriously injured by a bombing in the mosque of his compound. He is flown to Saudi Arabia for treatment, leaving the country rudderless. 


$\begin{array}{ll}\text { Yemen 2011-11-23 } & \text { After months of evasive maneuvering, the Yemeni president Ali Abd- } \\ & \text { uleh Saleh flies to Riyadh, Saudi Arabia, to sign a transition document } \\ & \text { brokered by Arab and American diplomats. } \\ \text { Yemen 2014-09-10 } & \begin{array}{l}\text { In Yemen, the Houthi rebels, now in league with the former Yemeni } \\ \text { president Ali Abdullah Saleh, capture Sanaa, becoming the country's de } \\ \text { facto rulers. }\end{array}\end{array}$

Table 11: Verbatim descriptions of Arab Uprising events from Worth (2016) 


\section{E.2 Venezuela}

\begin{tabular}{|c|c|c|}
\hline Date & Source & Description \\
\hline Feb 2014 & Briceno-Ruiz & $\begin{array}{l}\text { Between February and April, street protests occur supporting the Exit, } \\
\text { a proposal pushed by Leopoldo Lopez, Antonio Ledezma, and Maria } \\
\text { Corina Mochado to oust the regime. Protests are brutally suppressed. }\end{array}$ \\
\hline Dec 2014 & Briceno-Ruiz & $\begin{array}{l}\text { Maduro calls extraordinary session of the National Assembly during re- } \\
\text { cess to appoint his own judges, which would have been appointed by the } \\
\text { National Assembly in } 2016 \text {. }\end{array}$ \\
\hline Dec 2015 & Gutierrez & $\begin{array}{l}\text { Maduro and Chavismo suffer significant electoral defeat when the oppo- } \\
\text { sition obtains the necessary majority in the National Assembly. }\end{array}$ \\
\hline Dec 2015 & Briceno-Ruiz & $\begin{array}{l}\text { Vacation is suspended in the Supreme Court to hear a case against the } \\
\text { results of the National Assembly election, which holds Opposition in } \\
\text { contempt. }\end{array}$ \\
\hline 2016-01-15 & Gutierrez & $\begin{array}{l}\text { Maduro begins governing using an illegal decree of economic emergency, } \\
\text { which has not been approved by the National Assembly. }\end{array}$ \\
\hline Apr 2017 & Briceno-Ruiz & $\begin{array}{l}\text { A new wave of protests occurs from April to August 2017, and which } \\
\text { are repressed violently by government. Torture, arbitrary arrests and } \\
\text { human rights violations of young leaders occurs. }\end{array}$ \\
\hline 2019-01-05 & Briceno-Ruiz & $\begin{array}{l}\text { Condeming Maduro for usurping controversial May } 2018 \text { elections, the } \\
\text { National Assembly declares Juan Guaido National Assembly president } \\
\text { for the } 2019 \text { period. }\end{array}$ \\
\hline 2019-01-13 & Briceno-Ruiz & $\begin{array}{l}\text { Guaido is arrested and then released by members of the Bolivarian In- } \\
\text { telligence Service (SEBIN), in a police raid, after which he is freed. A } \\
\text { muddled explanation from the Minister of Information says it is carried } \\
\text { out by rogue elements. }\end{array}$ \\
\hline 2019-01-21 & Briceno-Ruiz & $\begin{array}{l}\text { The Supreme Court, controlled by Maduro, declares Guaido's appoint- } \\
\text { ment null, and all acts that arrive from it void. }\end{array}$ \\
\hline 2019-01-23 & Briceno-Ruiz & $\begin{array}{l}\text { Guaido calls for a huge protest on January } 23 \text {, a symbolic day for } \\
\text { Venezuelans marking when former dictator Marcos Peres Jimenez was } \\
\text { overthrown in } 1958 \text {. }\end{array}$ \\
\hline 2019-01-24 & Briceno-Ruiz & $\begin{array}{l}\text { The high military commander, controlled by Chavismo, gives his uncon- } \\
\text { ditional support to Maduro. }\end{array}$ \\
\hline 2019-01-25 & Briceno-Ruiz & $\begin{array}{l}\text { In a public appearance in front of 1,000 Venezuelans in Caracas, Guaido } \\
\text { declares himself interim president of Venezuela. Mass protests begin. }\end{array}$ \\
\hline
\end{tabular}

Table 12: Verbatim descriptions of Venezuelan events 2013-2019 from Gutierrez (2017) and BriceñoRuiz (2019) 


\section{E.3 Thailand}

\begin{tabular}{|c|c|c|}
\hline Date & Source & Description \\
\hline $2006-01-23$ & Keyes & $\begin{array}{l}\text { Protests intensify when Thaksin and his family sell their holdings worth } \\
\text { nearly two billion bhat in the telecommunications Shin Corporation to } \\
\text { a Singapore holding company (Temasek) without incurring any taxes. } \\
\text { Tax avoidance seen as corruption. }\end{array}$ \\
\hline 2006-01-01 & Keyes & $\begin{array}{l}\text { By January or February, a large but loosely-connected movement begins } \\
\text { to mobilize protests calling for Thaksin's resignation. The movement, } \\
\text { which takes the name People's Alliance for Democracy (PAD), begins } \\
\text { with attacks on Thaksin's ethical conduct. }\end{array}$ \\
\hline 2006-03-08 & Keyes & Maha Bau gives his support to the protests led by the PAD. \\
\hline 2006-09-19 & Keyes & $\begin{array}{l}\text { The army, led by General Soonthi Boonyaratglin, stages a coup. } \\
\text { Thaksin's supporters put up no resistance and no blood is shed. }\end{array}$ \\
\hline 2008-03-01 & Prasirtsuk (2009) & $\begin{array}{l}\text { The pro-Thaksin PPP intensifies ammendment efforts to protect } \\
\text { Thaksin's political interests, and in response the People's Alliance for } \\
\text { Democracy (PAD), which had staged the anti-Thaksin yellow shirt cam- } \\
\text { paign in } 2005 \text {, returns to the streets. }\end{array}$ \\
\hline 2008-08-26 & Prasirtsuk (2009) & $\begin{array}{l}\text { The PAD declare Whistle Day, a campaign to disloding the Samak } \\
\text { (PPP) government through a siege of the Prime Minister's office com- } \\
\text { pound, National Broadcasting Televsion and other government agencies. }\end{array}$ \\
\hline 2008-09-01 & Prasirtsuk (2009) & $\begin{array}{l}\text { Major violence erupts when a red shirt mob clashes with PAD protestors } \\
\text { near Government House. One person is killed and several injured, and } \\
\text { the police fail to stop violence. }\end{array}$ \\
\hline
\end{tabular}

2008-10-07 Prasirtsuk (2009) PAD demonstrators surround the parliament building to protest the newly established Somchai government during its first policy address. The demonstrators meet opposition from riot-police, and police fire tear gas into the crowd. Two people are killed and more than 400 injured, many critically.

2008-10-15 Prasirtsuk (2009) Dispute over the Preah Vihear Temples leads to fighting between Thai and Cambodian soldiers after a long stand-off, resulting in one dead and many casualties. PM Somchai and Cambodian PM Hun Sen negotiate a peace settlement in late October.

2008-11-26 Prasirtsuk (2009) The PAD escalate their pressure by seizing both major airports in Bangkok (Suvanaphumi and Donmuang) on November 26 in a blackmail strategy to paralyze the government.

2009-04-01 Prasirtsuk (2010) Red shirts take over the Association of Southeast Asian Nations (ASEAN) meeting in the spring, prompting a subsequent government crackdown in Bangkok. 


\begin{tabular}{|c|c|c|}
\hline 2010-03-01 & Dalpino & $\begin{array}{l}\text { Large red shirt protests converge on the Phan Fah Bridge in Bangkok, } \\
\text { while entering into talks with government. }\end{array}$ \\
\hline 2010-04-10 & Dalpino & $\begin{array}{l}\text { The failure of Thai security forces to disperse the protestors emboldens } \\
\text { red shirts to seize the commercial Ratchaprasong area of Bangkok. }\end{array}$ \\
\hline 2010-04-08 & Dalpino & $\begin{array}{l}\text { Abhisit declares a state of emergency, but is reluctant to order a full } \\
\text { crackdown and continues to negotiate with the red shirts on elections. } \\
\text { Grenade attacks and clashes continue. }\end{array}$ \\
\hline 2010-05-01 & Dalpino & $\begin{array}{l}\text { Just hours after government forces erect borders around Rachaprasong } \\
\text { to cordon off protestors, Major General Khattiya Sawasdiphol, self- } \\
\text { appointed security advisor to the protestors, is hit by sniper fire after } \\
\text { an NYT interview. }\end{array}$ \\
\hline 2010-05-01 & Dalpino & $\begin{array}{l}\text { Red shirt leaders surrender or go underground, and protestors set } 39 \\
\text { buildings on fire, including the stock exchange and Central World mall. } \\
\text { Estimates count } 91 \text { dead. }\end{array}$ \\
\hline 2011-07-01 & Baker & $\begin{array}{l}\text { The victory of Thaksin's sister, Yingluck, at elections in July } 2011 \\
\text { crushes the opposition coalition's hopes of destroying Thaksin's influ- } \\
\text { ence within the political structure developing since } 1970 \text {. }\end{array}$ \\
\hline 2013-10-31 & Baker & $\begin{array}{l}\text { Government botches the passage of an amnesty bill [for Thaksin sup- } \\
\text { porters] on the night of October 31st. From that point onwards there } \\
\text { are almost } 6 \text { monthes of protest which created the context for the coup. } \\
\text { The initial protest against the amnesty bill took the form of flash mobs } \\
\text { organized through social media. }\end{array}$ \\
\hline 2014-01-24 & Baker & $\begin{array}{l}\text { Through the media and public platforms, groups drawn from the official } \\
\text { and professional elite issue statements calling for the overthrow of the } \\
\text { government. In February 2014, Council of Univesity Presidents calls on } \\
\text { the government to resign on the grounds that violence was rising and } \\
\text { the economy sinking. }\end{array}$ \\
\hline 2014-05-20 & Prasirtuk (2015) & $\begin{array}{l}\text { Three months after post-election stalemate, on May } 20 \text {, the military } \\
\text { declares martial law to restore peace and stability. }\end{array}$ \\
\hline 2014-05-22 & Prasirtuk (2015) & $\begin{array}{l}\text { Army Commander General Prayuth Chan-ocha calls leaders of both } \\
\text { sides to a negotiation table at the army club, acting as mediator. On } \\
\text { May } 22 \text {, after talks fail, Prayuth abruptly declares the coup. }\end{array}$ \\
\hline
\end{tabular}

Table 13: Verbatim descriptions of Korean events 2016-2017 from Kim (2017) 


\section{E.4 Color Revolutions}

\begin{tabular}{|c|c|c|}
\hline Country & Date & Description \\
\hline Serbia & $2000-09-24$ & $\begin{array}{l}\text { Incumbent president Slobodan Milosevic scheduled early presidential } \\
\text { elections for September } 24,2000 \text {, assuming that he will easily win. }\end{array}$ \\
\hline Serbia & 2000-09-26 & $\begin{array}{l}\text { The Yugoslav Election Commission announces that [rival] Kostunica has } \\
\text { gained the most support with } 48.2 \text { percent of the vote, and in a second } \\
\text { round run-off will face Milosevic. }\end{array}$ \\
\hline Serbia & 2000-10-05 & $\begin{array}{l}\text { Opposition leaders call for a total blockade of all institutions in Serbia, } \\
\text { and over } 200,000 \text { people take to the streets of Belgrade.... Over half a } \\
\text { million people march on Belgrade and quickly seized control of major } \\
\text { government institutions. }\end{array}$ \\
\hline Serbia & 2000-10-06 & The following day, Milosevic resigns. \\
\hline Georgia & 2003-11-02 & $\begin{array}{l}\text { Following the November } 2,2003 \text {, Georgian parliamentary elections, } \\
\text { small-scale protests begin in Tbilisi as various reports of fraud begin } \\
\text { to accumulate. }\end{array}$ \\
\hline Georgia & 2003-11-22 & $\begin{array}{l}\text { These protests come to a head as Shevardnaze tries to address the in- } \\
\text { augural session of the newly elected parliament. }\end{array}$ \\
\hline Georgia & 2003-11-23 & $\begin{array}{l}\text { After originally claiming that he would not step down, Shevardnaze } \\
\text { resigns the following day. }\end{array}$ \\
\hline Georgia & 2004-01-04 & $\begin{array}{l}\text { New presidential elections are set for January } 4,2004 \text {, which Saakashvili } \\
\text { wins with } 96 \text { percent of the vote in an essentially uncontested election. }\end{array}$ \\
\hline Ukraine & 2004-10-31 & $\begin{array}{l}\text { On October } 31,2004 \text {, Viktor Yanukovich, the officially anointed succes- } \\
\text { sor to the regime of outgoing president Leonid Kuchma, and opposition } \\
\text { leader Viktor Yushchenko, receive } 39.3 \text { percent and } 39.9 \text { percent of the } \\
\text { vote, respectively. }\end{array}$ \\
\hline Ukraine & 2004-11-21 & $\begin{array}{l}\text { As neither surpass the } 50 \text { percent threshold necessary for a first-round } \\
\text { victory, the two advance to a November } 21 \text { run-off. After reports of } \\
\text { voter fraud, the Central Election Commission declares Yanukovich the } \\
\text { winner by a } 49.5 \text { percent to } 46.6 \text { percent margin. }\end{array}$ \\
\hline Ukraine & 2004-11-27 & $\begin{array}{l}\text { Over the following weeks, the protests continue in Kiev despite frigid } \\
\text { conditions. }\end{array}$ \\
\hline Ukraine & 2004-12-03 & $\begin{array}{l}\text { The crisis is resolved peacefully through existing institutions follow- } \\
\text { ing a parliamentary resolution declaring the results invalid. Ukraine's } \\
\text { Supreme Court on December } 3[\ldots] \text { declares the second round election } \\
\text { results to be invalid and orders that the round be run again on December } \\
26 \text {. }\end{array}$ \\
\hline Ukraine & $2004-12-26$ & $\begin{array}{l}\text { The second round features over } 12,000 \text { international observers, and } \\
\text { Yushchenko wins with } 52.0 \text { percent to } 44.2 \text { percent. }\end{array}$ \\
\hline
\end{tabular}


Kyrgyz Rep. 2005-02-27 The February 27 and March 13, 2005, parliamentary elections follow a change in the composition of the Kyrgyz Parliament and the election rules used to select members for that body.

Kyrgyz Rep. 2005-03-15 Protests begin in the southern Kyrgyz city of Jalalabad demanding Akaev's ouster, and over the next week spread to other parts of the country including Talas and Osh. These protests culminate two weeks later with 30,000 protesters converging in the main square of Bishkek.

Kyrgyz Rep. 2005-04-04 Akayev eventually agrees to resign.

Kyrgyz Rep. 2005-07-10 Kurmabek Bakiyev is elected president with over 88 percent of the vote, but the fraudulently-elected parliament is allowed to continue to operate without elections as a part of negotiations between the various opposition groups.

Table 14: Verbatim descriptions of Color Revolutions from Tucker (2007) 


\section{E.5 Philippines 1986}

\begin{tabular}{|c|c|c|}
\hline Date & Source & Description \\
\hline 1986-02-07 & Schock & $\begin{array}{l}\text { As a response to rising protests, Marcos calls for snap elections to be } \\
\text { held on February } 7,1983 \text {. }\end{array}$ \\
\hline $1986-02-16$ & Schock & $\begin{array}{l}\text { Widow of Benigno, Corazon Aquino, responding to the fraudulent dec- } \\
\text { laration of electoral victory for Marcos by the Batasang Pambansa (na- } \\
\text { tional assembly), led a rally of over two million people, proclaiming } \\
\text { victory for herself and the people against Marcos. }\end{array}$ \\
\hline $1986-02-22$ & Schock & $\begin{array}{l}\text { Defense Minister Jaun Ponce Enrile leads two battalions of soldiers in a } \\
\text { mutiny, barricading two military camps in Quezon City. He is joined by } \\
\text { General Fidel Ramos, and they announce their withdrawel of support } \\
\text { from Marcos for Aquino. }\end{array}$ \\
\hline 1986-02-23 & Schock & $\begin{array}{l}\text { Manila Archbishop Jamie Cardinal Sin condemnes the election as fraud- } \\
\text { ulent, declaring that the regime has lost its moral authority to govern, } \\
\text { and urging people to nonviolently resist the Marcos dictatorship. In } \\
\text { response, hundreds of thousands assemble near military camps. }\end{array}$ \\
\hline $1986-02-25$ & Schock & $\begin{array}{l}\text { Marcos orders two battalions to the military camps to put down the } \\
\text { mutiny, but as the tanks approach civilians form human barricades. } \\
\text { The loyalist troops retreat in the face of mass unarmed civilians led by } \\
\text { priests and nuns, which sparks nationwide defections. }\end{array}$ \\
\hline $1986-02-26$ & Schock & $\begin{array}{l}\text { Corazon Aquino is sworn in as president and Marcos is escorted to } \\
\text { Honalulu by the US military. }\end{array}$ \\
\hline
\end{tabular}

Table 15: Verbatim descriptions of Korean events 2016-2017 from Kim (2017) 


\section{E.6 Korea 1987}

\begin{tabular}{|c|c|c|}
\hline Date & ource & Description \\
\hline 986 & e & $\begin{array}{l}\text { After protests at Geonguk University in October 1986, the Chun gov- } \\
\text { ernment harshly surppreses the protesting students and claims they are } \\
\text { supporters of the communist North Korean regime. }\end{array}$ \\
\hline 1987-01-14 & Choe & $\begin{array}{l}\text { Many Korean citizens participate in a protest condemning the Chun } \\
\text { regime for killing Park Jong Chul, a student activist, under torture. }\end{array}$ \\
\hline 1987 & Choe & $\begin{array}{l}\text { The Chun government announces Protection of the Constitution, revok- } \\
\text { ing promise and prohibiting any discussion of constitutional revision, a } \\
\text { peaceful government transfer under the provisions of the present con- } \\
\text { stitution, or the enforcement of the presidential election by the end of } \\
1987 \text {. }\end{array}$ \\
\hline 1987 & Choe & $\begin{array}{l}\text { Nationwide democratic movement known as June Struggle begins, and } \\
\text { more than } 400,000 \text { participate despite the Chun government mobilizing } \\
60,000 \text { police to supress the rallies. }\end{array}$ \\
\hline 1987-06-26 & Choe & $\begin{array}{l}\text { More than 1,400,000 people in all parts of country join the democratic } \\
\text { movements under the slogan of 'Cancellation of the April } 13 \text { Announce- } \\
\text { ment of the Protection of the Constitution and Constitutional Revision } \\
\text { of Direct Presidential Elections'. }\end{array}$ \\
\hline 1987-06-29 & Choe & $\begin{array}{l}\text { The Chun government makes a democratic declaration and agrees to } \\
\text { constitutional revision for direct presidential elections. }\end{array}$ \\
\hline
\end{tabular}

Table 16: Verbatim descriptions of Korean events 2016-2017 from Kim (2017) 


\section{E.7 End of Apartheid}

\begin{tabular}{|c|c|c|}
\hline Date & Source & Description \\
\hline Feb 1990 & Waldmeir & de Klerk legalizes the ANC and SACP and releases Mandela. \\
\hline 1990-03-26 & Klopp \& Zuern & $\begin{array}{l}\text { In a protest in Sebokeng, the police fire upon a crowd, killing seven- } \\
\text { teen unarmed protestors and injuring over } 400 \text {. The ANC responds by } \\
\text { suspending prenegotiation talks. }\end{array}$ \\
\hline 1990-07-14 & Klopp \& Zuern & $\begin{array}{l}\text { Inkatha's leader Mangosuthu Bethuelezi announces that Inkatha will } \\
\text { become a national political party open to all races: the Inkatha Freedom } \\
\text { Party (IPF). }\end{array}$ \\
\hline 1990-07-22 & Klopp \& Zuern & $\begin{array}{l}\text { Fighting between Inkatha and the ANC, which has become endemic in } \\
\text { KwaZulu-Natal, spreads to the Johannesburg area. }\end{array}$ \\
\hline Aug 1990 & Waldmeir & ANC announces it is suspending armed struggle; violence escalates. \\
\hline Dec 1990 & Waldmeir & $\begin{array}{l}\text { Start of formal multi-party talks, the Convention for a Democratic South } \\
\text { Africa (CODESA). }\end{array}$ \\
\hline 1991-07-25 & Klopp \& Zuern & $\begin{array}{l}\text { The Weekly Mail breaks Inkathagate, revealing a state-supported secu- } \\
\text { rity police operation that funded Inkatha in its violent campaign against } \\
\text { the ANC. }\end{array}$ \\
\hline Mar 1992 & Waldmeir & Whites-only referendum endorses reform. \\
\hline 1992-06-15 & Klopp \& Zuern & $\begin{array}{l}\text { When multiparty negotiations at the Convention for a Democratic South } \\
\text { Africa (CODESA) reach a deadlock, the ANC responds to the statement } \\
\text { with a promise to demonstrate. }\end{array}$ \\
\hline $1992-06-16$ & Klopp \& Zuern & $\begin{array}{l}\text { After ANC mass action begins, IFP supporters attack residents at Boipa- } \\
\text { tong. }\end{array}$ \\
\hline 1992-09-07 & Klopp \& Zuern & $\begin{array}{l}\text { After another massacre in Bisho, de Klerk, who had been employing the } \\
\text { continuing violence as a positioning strategy, recognized the pending } \\
\text { threat of a complete breakdown of negotiations. }\end{array}$ \\
\hline $1992-09-26$ & Klopp \& Zuern & $\begin{array}{l}\text { The ANC and the National Party sign the crucial Record of Understand- } \\
\text { ing on September } 26,1992 \text {, effectively marginalizing the IFP. }\end{array}$ \\
\hline Apr 1993 & Waldmeir & Chris Hani (head of ANC armed-wing) assassinated. \\
\hline Jul 1993 & Waldmeir & Agreement reached on election date, but IFP walks out of talks. \\
\hline Nov 1993 & Waldmeir & Agreement on an interim constitution. \\
\hline Dec 1993 & Waldmeir & $\begin{array}{l}\text { Transitional Executive Council, the multi-party interim government, be- } \\
\text { gins to operate. }\end{array}$ \\
\hline Mar 1994 & Waldmeir & Overthrow of Bophuthatswana (a Bhantuland), rout of the white right. \\
\hline 1994-04-27 & Klopp \& Zuern & $\begin{array}{l}\text { South Africa holds its first nonracial, democratic elections, with ANC } \\
\text { the victor. }\end{array}$ \\
\hline May 1994 & Waldmeir & Mandela is inaugurated. Government of National Unity formed. \\
\hline
\end{tabular}


Table 17: Verbatim descriptions of South African events 1990-1994 from Klopp \& Zuern (2007) (daily) and Waldmeir (1997) (monthly) 


\section{E.8 Korea 2016}

\begin{tabular}{|c|c|c|}
\hline Date & Source & Description \\
\hline Oct 2016 & Kim & $\begin{array}{l}\text { A scandal exposes that Choi, personal confidante of Park, has been } \\
\text { conspiring with the president to amass a fortune, shape national policy } \\
\text { and secure positions for her friends and relatives. }\end{array}$ \\
\hline Oct 2016 & Kim & $\begin{array}{l}\text { Blacklist is discovered and published by Hankook Ilbo showing that the } \\
\text { Park Administration targeted creative professionals who were seen as } \\
\text { anti-government. The blacklist includes over } 9,000 \text { visual artists, writers, } \\
\text { film directors, and others critical of the Sewol Ferry sinking. }\end{array}$ \\
\hline 2016-10-29 & Kim & $\begin{array}{l}\text { Beginning on October } 29 \text { th, weekly anti-Park protests are held on an } \\
\text { enormous scale for } 17 \text { consecutive weeks, }\end{array}$ \\
\hline 2016-11-11 & Kim & Candelight protest held on November 12, 2015. \\
\hline 2016-12-03 & Kim & $\begin{array}{l}\text { At protest height on December } 3 \mathrm{rd} \text {, the total estimate of people who } \\
\text { join the protests on a single day exceeds } 2.3 \text { million people across the } \\
\text { country - } 1.6 \text { milion in Seoul alone. }\end{array}$ \\
\hline 2016-12-09 & Kim & $\begin{array}{l}\text { After weeks of debate, on December } 9 \text { th the South Korean National } \\
\text { Assembly votes to pass an impeachment bill, holding that the President } \\
\text { has violated her oath of office as well as core tenets of the Constitution } \\
\text { and laws governing the operation of the presidency. }\end{array}$ \\
\hline 2017-01-07 & Kim & $\begin{array}{l}\text { Parents and relatives of the Sewol victims are prominently involved in } \\
\text { the Candlelight protests in Seoul and elsewhere. They carry a banner } \\
\text { with images of victims at a rally to commemorate the 1000-day anniver- } \\
\text { sary of the ferry sinking. }\end{array}$ \\
\hline 2017-03-09 & Kim & $\begin{array}{l}\text { Constitutional Court justices appear on national television, ruling 8-0 } \\
\text { to uphold the National Assembly vote on impeachment. }\end{array}$ \\
\hline 2017-05-09 & Kim & $\begin{array}{l}\text { In snap election held on May } 9 \text { th, liberal Moon Jae-in wins by a land- } \\
\text { slide, taking } 41 \text { percent of the vote, and begins his term. }\end{array}$ \\
\hline
\end{tabular}

Table 18: Verbatim descriptions of Korean events 2016-2017 from Kim (2017) 


\section{E.9 USIP Middle East Timelines}

\begin{tabular}{|c|c|c|}
\hline Country & Date & Description \\
\hline Iran & 1999-07-08 & $\begin{array}{l}\text { Students demonstrated at Tehran University after reformist Salaam } \\
\text { newspaper was closed by the judiciary. Protests continued for six days. } \\
\text { More than } 1,000 \text { students were arrested. }\end{array}$ \\
\hline Iran & 2003-06-10 & $\begin{array}{l}\text { Students led protests against raising university fees and privatization of } \\
\text { universities that grew into wider pro-democracy demands. They also } \\
\text { condemned President Khatami for failing to support them. }\end{array}$ \\
\hline Iran & 2007-06-27 & Protests erupted after the government imposed fuel rationing. \\
\hline Iran & 2009-06-13 & $\begin{array}{l}\text { The opposition Green Movement launched the most serious challenge to } \\
\text { the theocracy since the revolution. Millions turned out on the streets } \\
\text { of several Iranian cities for the next two weeks with banners declaring } \\
\text { Where is my vote? }\end{array}$ \\
\hline Iran & 2009-09-18 & $\begin{array}{l}\text { On Qods Day (or Jerusalem Day), thousands demonstrated across Iran } \\
\text { in support of opposition candidate Mousavi. A dominant slogan be- } \\
\text { came, No to Gaza and Lebanon. I will give my life for Iran, rejecting } \\
\text { the governments support of Palestinian and Lebanese militancy. Qods } \\
\text { Day marks the last Friday of the month of Ramadan, which Ayatol- } \\
\text { lah Khamenei had dedicated as a day of solidarity with the Palestinian } \\
\text { people }\end{array}$ \\
\hline Iran & 2009-11-04 & $\begin{array}{l}\text { On the anniversary of the U.S. Embassy takeover, tens of thousands of } \\
\text { protesters gathered across major cities. Instead of chanting Death to } \\
\text { America, protestors chanted, Death to the dictator, a reference to Irans } \\
\text { supreme leader. }\end{array}$ \\
\hline Iran & 2009-12-27 & $\begin{array}{l}\text { Commemorations on Ashoura, the holiest day for Shiites, turned into } \\
\text { violent anti-government protests. }\end{array}$ \\
\hline Iran & 2010-02-11 & $\begin{array}{l}\text { Both pro-government forces and members of the opposition movement } \\
\text { turned out onto the streets on the anniversary of the revolution. But } \\
\text { security forces prevented the opposition from mass protests, marking } \\
\text { the success of a crackdown against the Green Movement. }\end{array}$ \\
\hline Iran & 2011-02-14 & $\begin{array}{l}\text { The first mass anti-government demonstrations in a year took place } \\
\text { following uprisings throughout the Arab world. Violent clashes with } \\
\text { security forces reportedly left two dead. Opposition groups reported that } \\
1,500 \text { people were detained, but authorities said only } 150 \text { were detained. }\end{array}$ \\
\hline Iran & 2012-10-03 & $\begin{array}{l}\text { Iranian riot police broke up demonstrations at a major bazaar in Tehran. } \\
\text { Protestors blamed President Ahmadinejad for the plummeting value of } \\
\text { the rial. The bazaar closed for three days, due to the demonstrations. }\end{array}$ \\
\hline
\end{tabular}


Iran

Iran

Tunisia

Tunisia

Tunisia

Tunisia

Tunisia

Tunisia

Tunisia

Tunisia

Tunisia

Tunisia

Tunisia

Tunisia
2017-01-10 More than 2 million people reportedly participated in former President Rafsanjanis funeral procession, including top political figures. Some mourners took the opportunity to protest by chanting pro-opposition slogans so loudly that state television played music during the broadcast to drown the sound out.

2017-12-27 The Girls of Revolution Street protest movement against the mandatory hijab began. Female protesters recorded videos of themselves without a hijab, or waving their hijabs on street corners and other public places.

2010-12-17 Mohammed Bouazizi, a street vendor, set himself on fire to protest government corruption, igniting growing protests throughout the month.

2011-01-18 Protests escalated and spread nationwide. Police killed hundreds in confrontations.

Every Sunday, people protested nationwide for further reforms. (15)

Every Sunday, people protested nationwide for further reforms. (15)

2012-03-20 On the 56th anniversary of Tunisias independence from France, thousands marched in Tunis to call for a civil state. March 25

2012-05-20 Thousands rallied in Kairouan in support of Ansar al Sharia, a hardline Islamist group.

2012-06-12 In Tunis, Salafis rioted, protesting an art exhibit that they found offensive. One man was killed, 62 policemen were injured, and 160 protesters were arrested. A curfew was imposed.

2012-08-13 In Tunis, thousands protested a constitutional article that would lower womens status. Aug. 22

2012-09-12 Tunisians protested an anti-Islam film in front of the U.S. Embassy in Tunis. Salafis later stormed the compound and started fires inside the embassy.

2013-02-07 Protests erupted after leftist opposition leader Chokri Belaid was assassinated. Prime Minister Jebali promised to restructure the Islamistdominated government. He threatened to quit if his party did not support his plan to install a cabinet of technocrats. Jebali eventually resigned. Feb. 25

2013-07-25 Secular politician Mohamed Brahmi was assassinated, sparking largescale protests.

2016-05-11 Police carried out raids in Ettadamen, a Tunis suburb, and the southern town of Tataouine. Tunisian authorities said four police were killed when a suspected Islamist militant detonated a suicide-bomb belt during a raid in Tataouine. Four militants were killed in the raids. On the following day, Tataouine residents demonstrated against terrorism. 
Tunisia

Tunisia

Tunisia

Tunisia
2017-04-05 Employees of oil companies in Tataouine went on strike after 24 workers were laid off by Winstar, a Canadian company. Unemployed youth and other residents joined the protest to demand the creation of thousands of jobs and investment in a regional development fund. Hundreds of people started a sit-in between the main road and oil fields. Talks initially failed, but the Tunisian General Labour Union (UGTT) eventually joined the demonstration and facilitated another round of negotiations. The government and private companies accepted most of the protesters demands, and the sit-in ended on June 16.

2017-05-05 Employees of oil companies in Tataouine went on strike after 24 workers were laid off by Winstar, a Canadian company. Unemployed youth and other residents joined the protest to demand the creation of thousands of jobs and investment in a regional development fund. Hundreds of people started a sit-in between the main road and oil fields. Talks initially failed, but the Tunisian General Labour Union (UGTT) eventually joined the demonstration and facilitated another round of negotiations. The government and private companies accepted most of the protesters demands, and the sit-in ended on June 16.

2017-06-05 Employees of oil companies in Tataouine went on strike after 24 workers were laid off by Winstar, a Canadian company. Unemployed youth and other residents joined the protest to demand the creation of thousands of jobs and investment in a regional development fund. Hundreds of people started a sit-in between the main road and oil fields. Talks initially failed, but the Tunisian General Labour Union (UGTT) eventually joined the demonstration and facilitated another round of negotiations. The government and private companies accepted most of the protesters demands, and the sit-in ended on June 16.

2018-01-08 Tunisians protested price hikes on common goods and clashed with police in more than a dozen cities and towns. At least one person was killed and almost 800 people were arrested after five nights of protests. On January 14, government officials promised reforms, including an increase in government aid to needy families. Protests resumed after two days of calm in the capital. 
Tunisia

Tunisia

Tunisia

Tunisia

Iraq

Iraq
2018-11-22 Some 650,000 civil servants went on strike to protest mounting inflation and the governments refusal to raise wages. Thousands demonstrated nationwide. The prime minister had been under pressure from international lenders who threatened to stop financing Tunisias economy if the government did not tackle its large budget deficit. In November, nearly 750 protests, mainly over the economic situation, were held across Tunisia.

2018-12-24 Abderrazak Zorgui, a 32-year-old journalist, set himself on fire in the western city of Kasserine to denounce joblessness and desperate economic conditions He livestreamed the self-immolation on YouTube. His death ignited three days of protests that spread to several cities, including Tunis. In the eight years since the 2011 Jasmine Revolution, more than 300 Tunisians set themselves on fire to protest, according to Chaima Bouhlel, former president of Al-Bawsala, a Tunisian watchdog group. Another 2,000 made failed attempts in a reflection of the challenges facing Tunisias fragile democracy.

2019-01-17 The UGTT, the countrys largest union of 670,000 public servants, staged a massive strike to challenge the governments refusal to raise civil servant wages. The protesters gathered outside UGTT headquarters and Habib Bourghiba Avenue in Tunis and shouted many of the same slogans used in the 2011 revolution. The one-day strike affected ports, schools, hospitals, state media, and government offices.

2019-04-01 The government approved a 6.5 percent raise in minimum wages for industrial and agricultural workers to placate discontent. The move came two days after large demonstrations in Sidi Bouzid to protest deteriorating economic conditions.

2011-01-05 Shia cleric Moqtada al-Sadr returned to Iraq after three years of voluntary exile in Iran. In his first public statement, al-Sadr urged his followers to resist the occupiers of Iraq. On February 25, a Day of Rage swept the country as tens of thousands of Iraqis protested the newly elected government. Some 23 people were killed.

2012-12-28 Massive protests spread throughout Iraq in Fallujah, Ramadi, and Anbar province, all Sunni-majority areas. Tens of thousands of Sunnis demonstrated against the Shia-dominated government of Maliki. 
(15) The Sunni insurgency intensified across Iraq. Sectarian violence, kidnappings, and bombings escalated levels not seen since 2006 and 2007. On April 8, Baghdadi announced the absorption of the al Qaida-backed Nusra Front in Syria. He said the combined group would be known as the Islamic State in Iraq and Syria (ISIS). But the leader of the Nusra Front, Julani, rejected the merger and instead declared allegiance to al-Qaida. In April 2013, the Hawija regions anger at the government exploded after the Iraqi Army attacked Sunni protestors exercising what they considered civil disobedience. Up to 200 civilians were killed and at least 150 were injured. Such incidents fueled the surge of ISIS in the area the following year. By June 2014, ISIS had seized Hawija and much of southern Kirkurk, often with help from disaffected local residents. On July 21, 2013, ISIS launched its second 12-month campaign, Soldiers Harvest, on Iraqi security forces and to capture territory. On July 22, ISIS attacked Abu Ghraib prison freeing between 500 and 1000 inmates, including senior al-Qaida leaders and other militants.

Iraq

Iraq

Egypt

Egypt

Egypt

Egypt
2016-04-30 Supporters of al- Sadr broke into the Green Zone and stormed Parliament. Protesters demanded a new government to fight corruption after weeks of political gridlock and turmoil because parties insisted on appointing ministers along sectarian lines.

2018-09-15

2011-01-25 Organized on Facebook for a Day of Revolution on Jan. 25, tens of thousands of protesters nationwide called for President Hosni Mubaraks resignation. The government shut down the internet and blocked cell phone networks. Police killed hundreds of protesters over the next few weeks.

2011-02-25 Organized on Facebook for a Day of Revolution on Jan. 25, tens of thousands of protesters nationwide called for President Hosni Mubaraks resignation. The government shut down the internet and blocked cell phone networks. Police killed hundreds of protesters over the next few weeks. Feb. 25-26 Protesters in Tahrir Square called for Prime Minister Ahmed Shafiqs resignation, Mubaraks prosecution and faster reform. Police beat and forced them from the square. The SCAF later apologized for the brutality.

2011-03-04 Hundreds of protesters attacked the State Security Investigations headquarters in various cities and looked through documents.

2011-04-01 In Tahrir Square, thousands demonstrated to demand Mubaraks prosecution and faster reform. 
Egypt

Egypt

Egypt

Egypt

Egypt

Egypt

Egypt

Egypt

Egypt

Egypt
2011-05-27 In Tahrir Square, 100,000 people protested on a Second Day of Rage. The new government allowed the first free passage out of the Gaza Strip, a policy change from Mubaraks administration.

2011-06-26 After the trial of the former interior minister was postponed, police and thousands of protesters clashed in Tahrir Square, the most intense violence since the initial uprising. The army intervened on June 29.

2011-07-01 Protesters called for faster reforms in Tahrir Square on a Friday of Retribution.

2011-08-08 Dozens of Mubarak-era officials were charged with murder for their role in the January protests. Tens of thousands protested in Tahrir Square against the SCAF. The army forcibly cleared the square on August 1.

2011-09-09 Protests against the SCAF took place every Friday in Tahrir Square for several weeks.

2011-10-09 Protests against the SCAF took place every Friday in Tahrir Square for several weeks.

2011-12-01 Prominent activist Alaa Abd al-Fattah was arrested and charged with inciting violence against the military. Thousands in Tahrir Square protested his arrest. The government announced the release of 334 political prisoners after a letter by al Fattah was published. Nov. 18-29

2012-01-27 Tens of thousands rallied in Tahrir Square and called for SCAF to transfer power to a civilian government. After the final round of elections on January 3, the Muslim Brotherhood won 47 percent of parliamentary seats and Salafi Islamist parties took 27 percent of seats.

2012-04-12 Parliament passed a bill to bar former top Mubarak officials from running for office for 10 years. The next day, tens of thousands of Islamists protested against the candidacies of Mubarak-era officials. The election commission barred candidates

2012-06-16 The Tamarod (Rebel) movement issued a statement giving Morsi until 5 p.m. the following day to resign or risk facing complete civil disobedience. Before the June 30 protests, Tamarod had reportedly collected up to 22 million signatures for its petition demanding early elections. Several ministers resigned as demonstrations continued nationwide. General el-Sissi called the Morsi government to resolve the political crisis within 48 hours or face military intervention. The Salafi al-Nour Party called for early elections. 
Egypt

Egypt

Egypt

Egypt

Egypt

Egypt

2012-09-11 Thousands of Egyptians protested against an anti-Islam film, and some breached the walls of the U.S. Embassy in Cairo. They destroyed an American flag. President Obama expressed concern over the governments response to the situation in Cairo in a phone call with President Morsi. On the following day, Morsi explicitly denounced violent demonstrations and pledged to protect American citizens and property. Sept. $14-15$

2012-10-11 The constitutional assembly unveiled a new draft constitution that gave religion a more prominent role in the legislative and judicial process. Liberal and secular groups protested the insertion of Islam. Some ultraconservative Salafis also rejected the document, arguing that it did not adequately enshrine Islamic law.

2012-11-22 President Morsi issued a controversial decree exempting himself from judicial supervision and shielding the Constituent Assembly and Shura Council from dissolution by court order. The opposition condemned the moves and organized protests. Several of Morsis 21 advisors resigned.

2013-04-19 Thousands of Morsi supporters protested on April 19, calling for the ouster of Mubarak-era officials from judicial posts. Justice Minister Ahmed Mekki resigned ahead of a cabinet reshuffle. He had reportedly threatened to quit in November 2012 after Morsi adopted expansive powers.

2013-06-17 President Morsi appointed 17 new provincial governors, including seven Islamists. The most controversial appointee was the governor of Luxor, Adel al Khayat. He was a former member of the Islamist group Gamaa Islamiya, which claimed responsibility for killing 62 people, mostly foreign tourists, in 1997. The appointments led to protests in several governorates clashes between Brotherhood supporters and opponents. $\mathrm{Al}$ Khayat announced his resignation on June 23. June 30

2013-07-01 The Tamarod (Rebel) movement issued a statement giving Morsi until 5 p.m. the following day to resign or risk facing complete civil disobedience. Before the June 30 protests, Tamarod had reportedly collected up to 22 million signatures for its petition demanding early elections. The Egyptian military also issued an ultimatum. Several ministers resigned as demonstrations continued nationwide. General el-Sissi called the Morsi government to resolve the political crisis within 48 hours or face military interve July 5 
Egypt

Egypt

Egypt

Libya

Libya

Libya

Libya
2013-08-16 The Brotherhood called for a march of anger to protest the military coup and crackdowns on sit-ins. Hundreds of Morsi supporters gathered at a mosque in Cairos Ramses square after Friday prayers. Clashes with security forces and armed local residents left at least 173 dead including eight police officers. More than 1,300 were reportedly injured. Protestors barricaded themselves in al Fatah mosque. The next day, security forces cleared people out after gunmen reportedly shot down at them from a minaret.

2013-10-06 At least 53 people were killed and 200 were injured in clashes between Morsi supporters and security forces on the 40th anniversary of Egypts 1973 attack on Israel. Authorities detained more than 400 people reportedly involved in the violence.

2013-11-24 The government issued a new law banning unauthorized public gatherings of more than 10 people. Demonstrators would risk spending seven years in prison for using violence or one year for covering their faces or protesting outside of a place of worship. Participants would be fined up to $\$ 1,500$ dollars. The Freedom and Justice Party condemned the new law. The Brotherhood continued to organize large anti-coup demonstrations across Egypt.

Secular groups like the April 6 Youth Movement and human rights groups also criticized the new law.

2011-02-15 In Benghazi, a small rally demanded the release of a human-rights lawyer and condemned a prison massacre. The civil protest grew into a large anti-Qaddafi demonstration. Police and government forcibly tried to quash it.

2012-03-06 Despite protests against them, leaders of eastern oil-rich Cyrenaica, including Benghazi, declared the province to be semi-autonomous. On March 7, NTC Chairman Jalil vowed to use force if necessary to prevent Cyrenaica from becoming autonomous.

2012-07-01 Protesters stormed Benghazis election headquarters and burned ballots after the eastern third of Libya was denied its request for one-third of assembly seats.

2012-09-11 Heavily armed Islamic militants attacked the U.S. consulate in Benghazi, killing Ambassador Chris Stevens, three members of his staff and 10 Libyan security guards. For the next three days, Libyans protested the killing of American diplomatic staff in major Libyan cities. Libyan officials blamed al Qaida-linked militants for the attack. 
Libya

West Bank \& Gaza

West Bank \& Gaza

West Bank \& Gaza

West Bank \& Gaza

West Bank \& Gaza

West Bank \& Gaza

West Bank \& Gaza
2014-02-03

February 7, when it was due to expire. Some members wanted to give a special assembly time to draft a new constitution. Secular militias from Zintan threatened to attack Tripoli in response. Thousands protested the extension, calling for new elections or a different political body to replace the GNC in the meantime

2011-03-15 Tens of thousands of Palestinians in Gaza and the West Bank took to the streets to call for unity among political factions. Hamas police used violence to disperse protests in Gaza.

2011-09-21 Thousands of Palestinians rallied across the West Bank to support the bid for statehood at the United Nations. More than 20 were injured in clashes between youths and Israeli soldiers in Ramallah.

2012-09-26 At least 500 protesters in Gaza called for the overthrow of Hamas after a three-year-old boy died in a fire during a power outage.

2012-10-23 Palestinian Authority employees in ministry offices, schools and clinics went on strike to protest cutbacks in services. Employees of the U.N. agency for Palestinian refugees also went on strike to protest cuts and the layoff of 130 workers. Qatars emir arrived in Gaza with a $\$ 250$ million aid package and became the first head of state to visit the blockaded territory since 2006.

2012-11-02 President Abbas appeared to make a symbolic concession to Israel during a television interview. He said that he had no right to live in Safed, the town from which his family fled during the 1948 war. His comments seemed to negate the Palestinian refugees claim to a right of return. Abbas retracted his remark after it sparked large protests in Gaza. He later clarified in another interview that he would personally give up living in Safed, but that he was not forfeiting the Palestinean right of return.

2012-12-14 Hamas held rallies across West Bank cities with the permission of the Palestinian Authority for the first time in five years. Dec. 19

2014-07-02 Mohamed Abu Khdeir, a 16-year-old Palestinian from Jerusalem, was abducted near his home and burned to death by Israeli extremists seeking revenge for the deaths of three Israeli teens. Violent protests ensued. Militant groups in Gaza fired rockets in the following days. 
West Bank \& Gaza 2018-02-16 A bomb attached to a Palestinian flag and placed along the Gaza border during Friday protests injured four Israeli soldiers. Israel responded with tank fire on a Palestinian observation post and then launched airstrikes on six targets. Hamas responded with rockets from Gaza. Israel retaliated once again with more tank fire and a second wave of airstrikes on 18 Hamas targets.

West Bank \& Gaza 2018-03-30 Tens of thousands of Gazans began six weeks of Friday protests called the Great March of Return at the border fence with Israel. Initially led by independent activists, the demonstrations were co-opted by Hamas. Demonstrators threw Molotov cocktails, launched stones with slings, burned tires, or sought to breach the fence. Israel responded with live fire, killing more than 100 Palestinians and wounding thousands. For the rest of 2018, protests at the fence persisted with fluctuating intensity. They flared up in May, during the opening of the U.S. Embassy in Jerusalem on May 14 and subsequently persisted with varying levels of intensity.

West Bank \& Gaza 2018-04-30 Tens of thousands of Gazans began six weeks of Friday protests called the Great March of Return at the border fence with Israel. Initially led by independent activists, the demonstrations were co-opted by Hamas. Demonstrators threw Molotov cocktails, launched stones with slings, burned tires, or sought to breach the fence. Israel responded with live fire, killing more than 100 Palestinians and wounding thousands. For the rest of 2018, protests at the fence persisted with fluctuating intensity. They flared up in May, during the opening of the U.S. Embassy in Jerusalem on May 14 and subsequently persisted with varying levels of intensity.

West Bank \& Gaza 2018-05-30 Tens of thousands of Gazans began six weeks of Friday protests called the Great March of Return at the border fence with Israel. Initially led by independent activists, the demonstrations were co-opted by Hamas. Demonstrators threw Molotov cocktails, launched stones with slings, burned tires, or sought to breach the fence. Israel responded with live fire, killing more than 100 Palestinians and wounding thousands. For the rest of 2018, protests at the fence persisted with fluctuating intensity. They flared up in May, during the opening of the U.S. Embassy in Jerusalem on May 14 and subsequently persisted with varying levels of intensity. 


\begin{tabular}{|c|c|c|}
\hline West Bank \& Gaza & $2018-07-13$ & $\begin{array}{l}\text { Protests along Gazas border with Israel turned violent. Palestinians } \\
\text { threw grenades and other explosive objects at the fence and Israeli troops } \\
\text { responded with tear gas and live fire. On the following day, Hamas fired } \\
\text { more than } 200 \text { projectiles, including rockets and mortars, into Israel. } \\
\text { Israeli jets targeted dozens of Hamas military targets in what Prime } \\
\text { Minister Netanyahu described as Israels biggest attack on the group } \\
\text { since } 2014 \text {. }\end{array}$ \\
\hline
\end{tabular}

Table 19: USIP timeline of events in the Middle East 